\title{
A Study in Songs: Comparative Analyses of 20th century settings of William Blake's "Songs of Innocence and of Experience": Selections from Vaughan Williams's "Ten Blake Songs", Britten's "Songs and Proverbs of William Blake", and Rochberg's "Blake Songs: For Soprano and Chamber Ensemble"
}

Jennifer Berkebile

Follow this and additional works at: https://researchrepository.wvu.edu/etd

\section{Recommended Citation}

Berkebile, Jennifer, "A Study in Songs: Comparative Analyses of 20th century settings of William Blake's "Songs of Innocence and of Experience": Selections from Vaughan Williams's "Ten Blake Songs", Britten's "Songs and Proverbs of William Blake", and Rochberg's "Blake Songs: For Soprano and Chamber Ensemble"' (2017). Graduate Theses, Dissertations, and Problem Reports. 7300.

https://researchrepository.wvu.edu/etd/7300

This Dissertation is protected by copyright and/or related rights. It has been brought to you by the The Research Repository @ WVU with permission from the rights-holder(s). You are free to use this Dissertation in any way that is permitted by the copyright and related rights legislation that applies to your use. For other uses you must obtain permission from the rights-holder(s) directly, unless additional rights are indicated by a Creative Commons license in the record and/ or on the work itself. This Dissertation has been accepted for inclusion in WVU Graduate Theses, Dissertations, and Problem Reports collection by an authorized administrator of The Research Repository @ WVU.

For more information, please contact researchrepository@mail.wvu.edu. 


\section{A Study in Songs:}

Comparative Analyses of $20^{\text {th }}$ century settings of William Blake's Songs of Innocence and of Experience: selections from Vaughan Williams's Ten Blake Songs, Britten's Songs and Proverbs of William Blake, and Rochberg's Blake Songs: For Soprano and Chamber Ensemble

\section{Jennifer Berkebile}

Research Document submitted to the College of Creative Arts at West Virginia University

in partial fulfillment of the requirements for the degree of

\section{Doctor of Musical Arts in Vocal Performance}

Hope Koehler, Chair, DMA

Andrew Kohn, Research Advisor, Ph.D.

Mary Ferer, Ph.D. Emerita

Robert Chafin, MM

Lee Blair, MFA

Morgantown, West Virginia

2017

Keywords: William Blake, Songs of Innocence and of Experience,

Vaughan Williams, Britten, Rochberg

(C) Jennifer Berkebile 2017 
ProQuest Number: 10273766

All rights reserved

INFORMATION TO ALL USERS

The quality of this reproduction is dependent upon the quality of the copy submitted.

In the unlikely event that the author did not send a complete manuscript and there are missing pages, these will be noted. Also, if material had to be removed, a note will indicate the deletion.

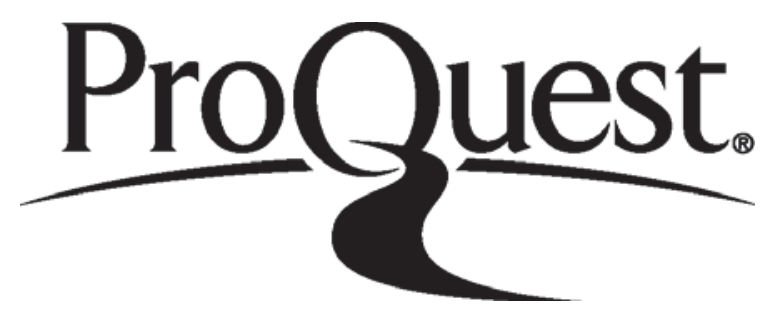

ProQuest 10273766

Published by ProQuest LLC (2017). Copyright of the Dissertation is held by the Author.

All rights reserved.

This work is protected against unauthorized copying under Title 17, United States Code Microform Edition (C) ProQuest LLC.

ProQuest LLC.

789 East Eisenhower Parkway

P.O. Box 1346

Ann Arbor, Ml $48106-1346$ 


\begin{abstract}
A Study in Songs:

Comparative Analyses of $20^{\text {th }}$ century settings of William Blake's Songs of Innocence and of Experience: selections from Vaughan Williams's Ten Blake Songs, Britten's Songs and Proverbs of William Blake, and Rochberg's Blake Songs: For Soprano and Chamber Ensemble
\end{abstract}

\title{
Jennifer Berkebile
}

The eighteenth-century poet, William Blake, is well-known today for his illuminated books, where a unique technique of relief etching allowed him to integrate text and illustration on a single printed copper plate, and his esoteric prophetic volumes. However, Blake's work went largely unrecognized during his lifetime and musical settings of Blake's poetry, in particular, are predominantly a twentieth and twenty-first century occurrence. With their distinctive styling and complicated interpretation, Blake's Songs of Innocence and Experience: Shewing the Two Contrary States of the Human Soul have provided material for many song settings over the course of the twentieth century and make for an interesting study of words and music.

Selections from three composers were chosen for the study: Ralph Vaughan Williams (1872-1953), Benjamin Britten (1913-1976), and George Rochberg (1918-2005). The study focuses on settings found in song cycles versus single pieces since a cycle (though not including all of the poems) would create the same sense of "variety within unity" that is evident in Blake's collection. The cycles chosen are also all composed within a fairly close time span to make the most out of comparing the compositional techniques between interpretations within a similar historical and cultural context. Finally, the compositions exhibit different styles and musical idioms of the twentieth century in order to highlight the multitude of relationships possible between music and words.

The heart of the discussion lies in the relationship between text and music in the song cycles of Vaughan Williams, Britten, and Rochberg and how their musical settings affect and enhance the Blake texts. The unique obstacles in setting the poetry of William Blake are explored along with a brief overview of Blake's work and cultural/historical environment and a detailed discussion of the poetic fundamentals of the Songs. A number of questions are considered when analyzing the selected poems and musical settings and conclusions are discussed at the end of the study. How do twentieth century musical idioms work with the early or pre-Romantic poetic style of Blake? Does the rearrangement of the poems from the original, carefully constructed volume alter the intentions of the creator or reveal new connections? How do the interpretations differ between composers? How, if at all, does the music attempt to portray the visual art included with the original poetry? What is the role of the performer in a work where the poetry is so well known as a stand-alone entity? 


\section{To Bradley,}

who supported, encouraged, and believed

To Lily,

who provided much needed snuggles 


\section{Acknowledgements}

It would not have been possible to complete this document without the assistance of many individuals throughout the process. Special thanks must go to my research advisor, Dr. Andrew Kohn, whose unending genius and honest criticism has inspired me throughout my time at WVU. The quality of this work has been greatly improved by his contributions and critiques, and I am extremely grateful for his help.

I wish to thank my committee chair and applied professor, Dr. Hope Koehler, for her encouragement and guidance over the past 6 years, and for sharing her knowledge, wisdom, and art with me.

I would like to express my gratitude to the rest of my committee, Dr. Mary Ferer, Professor Lee Blair, and Professor Robert Chafin, for their support and friendship through the course of my tenure at WVU. Every one of my committee members has made a great impact on the way I view singing, performing, and study, and I am forever grateful to have had the opportunity to work with each of them.

Finally, I would like to thank my husband, Bradley Smoak, and my little love, Lily. Thank you for understanding when it was time for "Mommy to work," and for always making me feel loved and encouraged. I love you both very much! 


\section{Table of Contents}

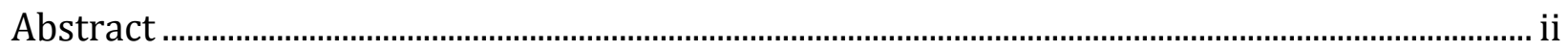

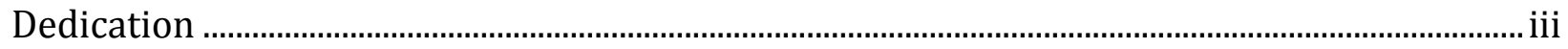

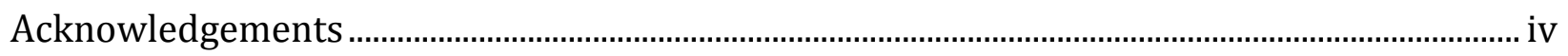

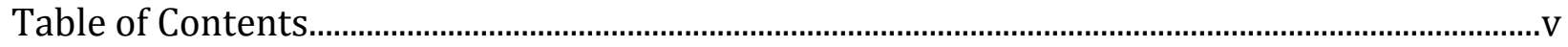

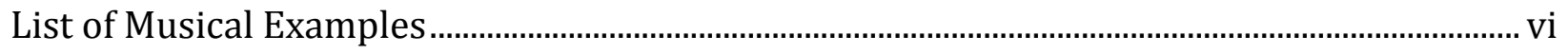

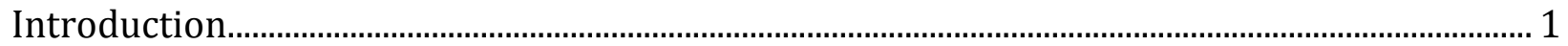

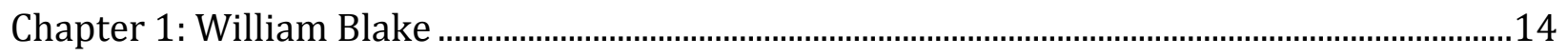

Chapter 2: Songs of Innocence and of Experience ..............................................................................28

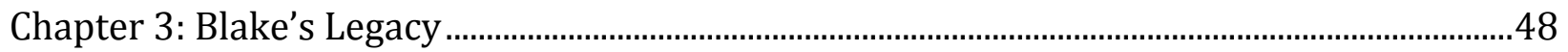

Chapter 4: The Composers and Their Cycles …...........................................................................64

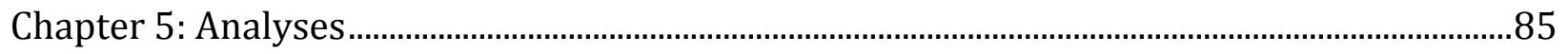

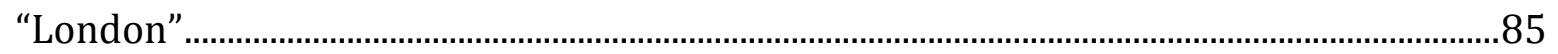

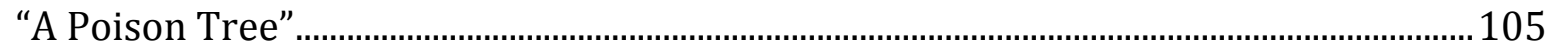

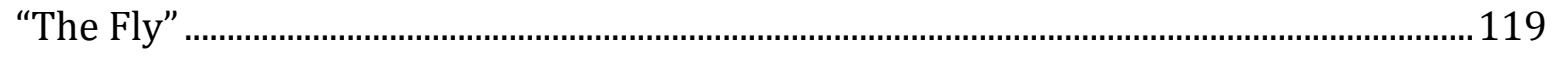

“The Lamb” \& "The Tyger" ..................................................................................................... 138

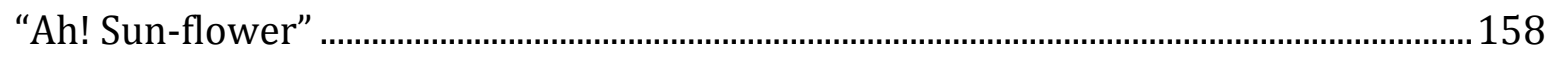

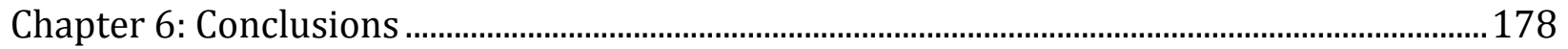

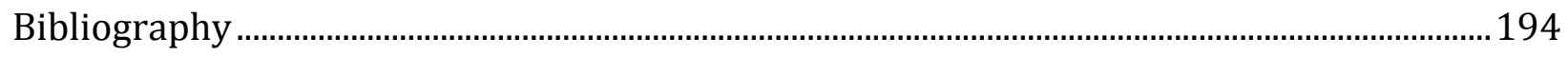

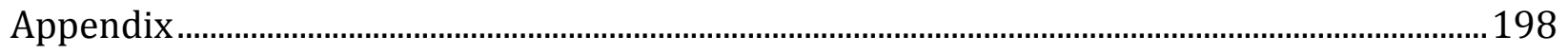

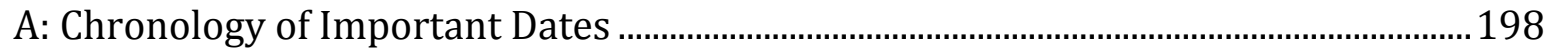

B: Extra Plates and Images ................................................................................................... 199

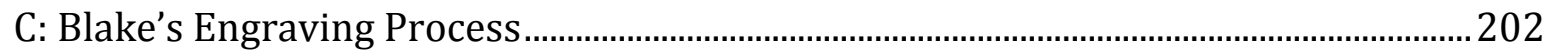

D: List of Standard Variations in English Metrics................................................................. 203

E: Songs of Innocence and of Experience — Plates for Analysis ............................................ 204

F: Tone Row Matrix — Rochberg's Blake Songs .................................................................... 210 


\section{List of Musical Examples}

Example 1: Vaughan Williams, "London," measures 7-10 Reduction ..........................................92

Example 2: Vaughan Williams, "London," Unifying Rythmic Motive on "ev-e-ry" ....................92

Example 3: Vaughan Williams, "London," Motive Chart ........................................................................93

Example 4: Britten, "London," measures 1-4 Reduction..................................................................99

Example 5: Britten, "London," measures 13 \& 16 Piano Reduction .............................................102

Example 6: Vaughan Williams, "A Poison Tree," measures 10-14 Reduction ...........................109

Example 7: Vaughan Williams, "A Poison Tree," measures 29-31 Reduction ...........................111

Example 8: Britten, "A Poison Tree," measures 10-16, Motive Reduction.................................115

Example 9: Britten, "A Poison Tree," Vocal Phrase Inversion, measures 3-6 \& 9-14 ............117

Example 10: Britten, "The Fly," measures 35-39 Reduction ...........................................................128

Example 11: Rochberg, "The Fly," Vocal Line Pitch Content Chart ..............................................131

Example 12: Vaughan Williams, "The Lamb," Rhythmic Reduction, m. 2-3 \& 20-21 ............145

Example 13: Britten, "The Tyger," measures 1-3 Reduction............................................................151

Example 14: Britten, "The Tyger," Vocal Line Reduction, measures 10-12 \& 20-21 ..............151

Example 15: Britten, "The Tyger," measures 74-77 Reduction ....................................................154

Example 16: Vaughan Williams, "Ah! Sun-flower," Rhythmic Reduction, m. 4-7 .....................162

Example 17: Vaughan Williams, "Ah! Sun-flower," Modal Scales .................................................164

Example 18: Britten, "Proverb VI," measure 11 Reduction ............................................................167

Example 19: Rochberg, "Ah! Sun-flower," measures 1-2, 16-17, 22, \& 26 Reductions ........171

Example 20: Rochberg, "Ah! Sun-flower," Vocal Line Pitch Content Chart................................173

Example 21: Rochberg, "Ah! Sun-flower," Chord spellings...........................................................175 


\section{Introduction}

"In the beginning was the song." 1

(Lawrence Kramer)

I.

Song, in its infinite manifestations, has existed since before the beginning of written history. From Gregorian chant to modern-day gospel, seventeenth century opera to twenty-first century musical theater, ancient folk-song to today's top 40, the intertwining of words and voices has been a constant in all forms and genres of music from century to century. The genre on which the following discussion will focus is the classical Art Song: a self-contained musical composition where, according to Edward T. Cone, "a poem...is set to a precisely composed vocal line united with a fully developed instrumental accompaniment."2 The development of Art Song can be explored by examining the relationship between poetry and music, and the evolution of that relationship throughout history.

During the period from c. 1450 through 1600, vocal music was heavily determined by the words, whether secular (the singer-poets writing specifically for their songs of entertainment) or sacred (Biblical or liturgical texts meant for worship). Independent instrumental music had not yet reached the popularity it would encounter in the seventeenth century, so the structures and forms of the music were dictated by the structures and forms of the texts, with counterpoint leading the musical language. The

\footnotetext{
${ }^{1}$ Lawrence Kramer, Music and Poetry: The Nineteenth Century and After (Berkeley and Los Angeles: University of California Press, 1984), 1.

${ }^{2}$ Edward T. Cone, The Composer's Voice (Berkeley and Los Angeles: University of California Press, 1974), 5.
} 
reliance on text as the main provider of form in a musical composition led to the increasingly complex multi-voiced, multi-language motets of the 1570s to $1620 \mathrm{~s}$. Ironically, the words that were the basis of pieces became muddled and almost impossible to understand if one was not incredibly familiar with the original text.

With the advent of opera in the early seventeenth century, text was again considered with the utmost importance. Following the Florentine Camerata's call for ancient Greek inspiration and vocal monody, works like Claudio Monteverdi's (1567-1643) La favola d'Orfeo (1607) paid careful attention to the natural declamation of speech. Early opera sought to communicate text through syllabic melodies and expressive harmonies, including employing previously-frowned-upon dissonances in order to serve the meaning of the text. With the advent of public opera houses in Venice in the mid-1600s, opera became more like the genre we know today. Recitative and aria became distinct entities, libretti subjects became broader and demanded more stage spectacle, and the public's attraction to virtuosic singing led to the advent of the vocal "star." Many of the conventions that would form the basis of opera through the next century were already in place by the end of the 1600s.

We know that despite the Florentine Camerata's best intentions, opera during the Baroque period became less and less tied to the text. Libretti became formulaic with a hierarchy of characters, rather than the story, dictating the action. Baroque greats like Handel composed in the standard da capo form where the lines of text were written short and simple to "permit the composer to fill out his musical form with the word and phrase 
repetitions, the melismas, and the cadenzas typical of the late Baroque Italian opera." ${ }^{3}$ By the mid-1700s, however, the public began to turn away from the obscure characters, excessive virtuosic arias, and convoluted plots of opera seria in favor of the accessibility and efficiency of opera buffa and the Classical style.

One result of the Baroque rise of music and formula over text, as pointed out by Edward Cone in his "Words into Music" essay, was that "serious" poets began to turn their attention away from the thought of musical settings for their work. ${ }^{4}$ The two arts had diverged. There are always exceptions, naturally. Early Italian composers such as Marc'Antonio Cesti (1623-1669), Antonio Lotti (1667-1740), and Alessandro Scarlatti (1660-1725) wrote songs to poetic texts, which remain in the current repertoire. ${ }^{5}$ In the Classical period, Mozart and Beethoven continued the tradition with writing classical songs concentrating on beautiful melodies that focus on the text with equally beautiful, albeit simple, accompaniments. Beethoven furthered the style even more by contributing the first Song Cycle to the growing genre. An die ferne Geliebte, written in 1816, was a turning point in the composition of song. The combining of absolute music forms (in this case, theme and variations), extensive involvement of the piano in both structure and mood, and the use of unifying motives at the beginning and the end of the piece anticipate the art song styles of

\footnotetext{
${ }^{3}$ Edward T. Cone, "Words into Music: The Composer's Approach to the Text," in Music: $A$ View from Delft, ed. Robert P. Morgan (Chicago: University of Chicago Press, 1989), 116. ${ }^{4}$ Ibid.

${ }^{5}$ Barbara Meister, "The Interaction of Music and Poetry: A Study of the Poems of Paul Verlaine as Set to Music by Claude Debussy and of the Song Cycle 'Songs and Proverbs of William Blake' by Benjamin Britten (France; England)," (PhD Diss., City University of New York, 1987), 6-7.
} 
Schubert and his contemporaries. ${ }^{6}$ From this point on, poets and musicians were looking to each other once again for inspiration.

Innovations in both everyday life and personal expression during the nineteenth century brought about many important artistic changes, which ushered in the development of the modern-day art song. A growing interest in folk song (the German volkstümliches Lieder and English popular ballads as examples), and the advent of a new poetry with freer, more expressive forms and lyrical verses "full of personal expression and awareness of self," had a great impact on composers. ${ }^{7}$ The writings of poets such as Goethe and Heine in Germany, Wordsworth and Keats in England, and later in France with Hugo and Baudelaire, provided the necessary depth of expression and imagery that allowed composers to widen the musical and dramatic scope of their songs. The social and political cultures around Europe in the early $19^{\text {th }}$ century also had an impact on how and where music was played and enjoyed. For example, in Vienna, the political climate was one of censorship and oppression with the Carlsbad Decrees of 1819, which censored press and restricted academic freedoms in the German states with the aim of "suppressing all liberal agitation against the conservative governments of Germany."8 People turned to privately organized functions for social interaction, resulting in the tradition of salon concerts and at-home music making. In connection with salon culture, the popularity of the pianoforte affected the development of art song. With its increased expressivity and abundant availability,

${ }^{6}$ Carol Kimball, Song: A Guide to Style and Literature (Redmond, Washington: Pst..., 1996), 59.

7 Ibid., 52.

8 "Carlsbad Decrees," The Columbia Encyclopedia, 6th ed., Encyclopedia.com, accessed October 16, 2016, http://www.encyclopedia.com/reference/encyclopedias-almanacstranscripts-and-maps/carlsbad-decrees. 
pianofortes created a demand for keyboard music and keyboard-accompanied song, and allowed composers to write fuller, more communicative accompaniments.

Art song, during this time, spread from country to country and began to take on stylistic characteristics unique to each nationality. The German Lied, often thought of as the "first" classical Art Song, began with the compositions of Franz Schubert (1797-1828). Schubert's pieces changed the concept of song by illustrating the story of the poetry through the accompaniment. For the first time, the piano was meant to be more than just background; it gave expression to the text. Voice and piano became equals, both tasked with evoking the images and emotions of the poetry, neither "in service of the other, both in service of the overall message of the text." 9

Schubert was followed by Robert Schumann (1810-1856), Johannes Brahms (18331897), and Hugo Wolf (1860-1903), among others, who continued the Lied tradition of melding music and poetry all while pushing the melodic and harmonic boundaries of the time. As the nineteenth century progressed, composers sought to expand the song form from stand-alone pieces to larger works, while keeping the same accessible qualities of Lieder. The song cycles of Schubert and Schumann took poems with common themes or storylines and grouped them into connected song sets, creating dramatic, extended works for performance. The scope of song quickly grew and graduated from personal salons to concert halls. By the end of the nineteenth century composers like Gustav Mahler (18601911) and Richard Strauss (1864-1949) were orchestrating song cycles, combining the post-romantic musical idioms of expanded harmonic structures, broader orchestral textures, and wide-ranging tonal colors into the genre of art song. While the twentieth

${ }^{9}$ Meister, "Interaction," 8. 
century saw a general decline of the Lied song form within the professional concert culture, important stylistic changes in vocal and instrumental writing would offer new techniques for text artistry. One of the most significant innovations in German composition at the beginning of the twentieth century was the work of Arnold Schoenberg (1874-1951) and his call for "the emancipation of the dissonance," resulting in a faction of composers who rejected the hierarchies of modern tonality in favor of atonal and serial structures. ${ }^{10}$ Schoenberg's use of atonality as a vehicle for art song, beginning with Das Buch der hängenden Gärten (1909), established the genre as a legitimate form of twentieth century artistic expression. His development of a new form of vocal writing, Sprechstimme, in works such as Pierrot Lunaire (1912), along with his continued use of atonality and the expansion into serialism, paved the way for his pupils Anton Webern (1883-1945) and Alban Berg (1885-1935). Both Webern and Berg had success writing for the voice in this new stylistic realm, Webern with songs written for voice and chamber ensemble and Berg with the atonal operas Wozzeck (1925) and Lulu (1937). The works of Schoenberg, Webern, and Berg ensured a place for atonality and specifically serial composition in the genre of song a technique that will be discussed in connection with both Benjamin Britten and George Rochberg.

Together with Germany, both France and England have rich histories in art song. Like its German relative, the French mélodie has its roots in early indigenous folk song and rose as a distinct form in the mid-nineteenth century. Though there are justifiable examples of early mélodie in the compositions of César Franck (1822-1890) and Emmanuel

${ }^{10}$ Arnold Schoenberg, "Opinion or Insight," in Style and Idea: Selected Writings of Arnold Schoenberg, ed. Leonard Stein, trans. Leo Blake (Berkeley and Los Angeles: University of California Press, 1975), 258. 
Chabrier (1841-1894), among others, mélodie is most often associated with Claude Debussy (1862-1918) and Gabriel Fauré (1845-1924). Romantic French poetry, such as the works of Paul Verlaine (a favorite of both Debussy and Fauré), highlights the musical resonances of words themselves, "the repetition of vowel sounds and alliteration, and [a] fascination with poetry as pure sensation." 11 This attention to the sonorous detail in poetry and the impressionistic idea of "art as suggestion" carries through to the mid-twentieth century and the works of Maurice Ravel (1875-1937) and Francis Poulenc (1899-1963), blending "precision with lyricism."12

English art song has a history of surges and lulls, flourishing in the sixteenth and seventeenth century, retreating in the eighteenth and early nineteenth century, and resurging again in the twentieth century. During the Elizabethan period marked by the reign of Queen Elizabeth I (1558-1603), England's supremacy in music and poetry was unmatched. The lute songs of John Dowland, Thomas Campion and the like, using the great poetry of their contemporaries (including William Shakespeare), were the dominant song form of the time. ${ }^{13}$ The later seventeenth century was marked by the vocal compositions of Henry Purcell, ranging from sacred to secular and anthems to operas. Purcell was praised for his prosody of the English language and his "natural and instinctively vocal" compositions, whose popularity continues to present day. ${ }^{14}$ In nineteenth century Victorian England, English music focused more on function than expression. Though songs were a part of everyday life in both the court and the theater, their simplistic strophic approaches left little to revel in artistically. However, England always retained a keen interest in its

${ }^{11}$ Kimball, Song: A Guide to Style and Literature, 155.

12 Ibid., 156.

13 Ibid., 301.

${ }^{14}$ Ibid., 307. 
song heritage and, by the beginning of the twentieth century, modern musical idioms were mixing with the musical language of folk songs and ballads to create a distinctly English song style. English composers (unlike those in Germany and France, who, generally, preferred present-day poets over past favorites) looked not only to contemporary poets like Thomas Hardy and A.E. Housman, but also to older poets within their rich history of literature and found inspiration in Shakespeare, Robert Herrick, and William Blake. The fascination with heritage continued through the twentieth century with the music of Ralph Vaughan Williams (1872-1956) and Gerald Finzi (1901-1956). The English song style, however, reached its apex with the music of Benjamin Britten (1913-1976). Particularly distinguished for his vocal music, Britten was the most prolific and famous English composer of the twentieth century, perfectly combining the variety of styles and techniques from English music over the centuries with modern musical idioms to create a unique, distinctly British, sound. ${ }^{15}$

Considering the history of European art song, American classical song is a relatively new phenomenon, evolving from the earliest parlor songs of Stephen Foster (1826-1864) to the accessible idioms of Ricky Ian Gordon (b. 1956) and Jake Heggie (b. 1961). The American "style" is as diverse as the country itself, mirroring the American "credo of individualism above all."16 As Carol Kimball states: "To hear the songs of Charles Ives, Charles Griffes, Samuel Barber, Ned Rorem, Virgil Thomson, John Duke, Paul Bowles, Lee Hoiby, Dominick Argento, and William Bolcom is to experience a kaleidoscope of sound and color, drama and emotion."17 The beginnings of American art song were rooted in

\footnotetext{
15 Ibid., 302.

16 Ibid., 227.

17 Ibid.
} 
European traditions. During the late nineteenth century and into the first half of the twentieth century, many American composers studied in Germany and adopted the Romantic German song style. Charles Griffes (1884-1920), for example, set almost an equal number of German and English texts. A number of famous American composers also studied in France with the renowned teacher, Nadia Boulanger (1887-1979). Among Boulanger's pupils were Virgil Thomson (1896-1989), Aaron Copland (1900-1990), and Theodore Chanler (1902-1961). ${ }^{18}$ The incredibly individualistic style of Charles Ives (18741954) is an exception. Ives was an American original and very ahead of his time, resulting in his music remaining largely unknown until much later in the century. Ives's innovative and experimental style was a great influence on later American composers and his art songs are now synonymous with Americana and a staple in both the studio and on the concert stage. The second half of the twentieth century saw a boom in American song and opera composition. Samuel Barber (1910-1981), Dominick Argento (b. 1927), and William Bolcom (b. 1938) are among the American composers who have created not only operas, but a substantial body of song literature as well. ${ }^{19}$ Because of the variety and originality of styles, it is difficult to pinpoint only a few composers within the evolving genre of American art song. The genre is still forming its legacy, and contemporary composers are eager to respond with songs that are equally varied and original.

II.

As mentioned earlier, during the twentieth century, English composers looked to poets from previous ages for inspiration. William Blake (1757-1827) is one such poet whose popularity with composers and critics rose during this time. William Blake's work

18 Ibid.

${ }^{19}$ Ibid. 
went largely unrecognized during his lifetime, but he is now considered one of the most important figures both in English literature and visual art. Today, he is well-known for his illuminated books, where a unique technique of "relief etching" allowed Blake to integrate text and illustration on a single printed copper plate. ${ }^{20}$ Blake's Songs of Innocence and Experience: Shewing the Two Contrary States of the Human Soul is an illuminated collection published as a complete set in 1794 , which consists of two volumes comprising 45 plated poems. With their distinctive styling and complicated interpretation, Blake's Songs have provided material for many song settings over the course of the twentieth century and make for an interesting study of words and music.

Musical settings of Blake's poetry are predominantly a twentieth and twenty-first century occurrence. After 1900, "the trickle of new musical settings of Blake's poetry becomes a flood."21 There are hundreds of settings of Blake's Songs alone, ranging from single art songs to full orchestral realizations. The styles and genres of the settings are just as varied: "austerely" monophonic (Vaughan Williams), English art song (Roger Quilter), song cycle (Virgil Thomson and Benjamin Britten), serial ensemble (George Rochberg), soft rock (the Norwegian musician Finn Coren's Blake Project), and folk (Greg Brown's Songs of Innocence and Experience), to name a few. ${ }^{22}$ Upon researching the plethora of available musical settings of the Songs, it became clear that a set of parameters was needed to make a cohesive research topic. This study focuses on settings found in song cycles versus single pieces since a cycle (though not including all of the poems) would create the same sense of

${ }^{20}$ Andrew Lincoln, introduction to Songs of Innocence and Experience, by William Blake (Princeton: Princeton University Press, 1991), 13.

${ }^{21}$ Keri Davies, "Blake Set to Music," in Blake 2.0: William Blake in Twentieth-Century Art, Music and Culture, ed. Steve Clark, Tristanne Connolly, and Jason Whittaker (New York: Palgrave Macmillan, 2012), 190.

22 Ibid., 191. 
"variety within unity" that is evident in Blake's collection. The cycles chosen are also all composed within a fairly close time span to make the most out of comparing the compositional techniques between interpretations within a similar historical and cultural context. Finally, the compositions exhibit different styles and musical idioms of the twentieth century in order to highlight the multitude of relationships possible between music and words.

Selections from three composers were ultimately chosen for the study: Ralph Vaughan Williams (1872-1953), Benjamin Britten (1913-1976), and George Rochberg (1918-2005). Vaughan Williams's Ten Blake Songs (1958), for voice and oboe, was composed for the documentary film The Vision of William Blake to commemorate the bicentennial of Blake's birth. The simple complexity of Vaughan Williams's music (a phrase examined later in the discussion) paired with the spare texture of the pieces (voice and obbligato instrument or voice alone) harken back to Blake's time of parlor songs and ballads. Britten's Songs and Proverbs of William Blake (Op. 74, 1965), for voice and piano, represents art song at its highest level. The complex relationships built by Britten offer an intellectual yet severely personal interpretation of the poetry. Finally, Blake Songs: For Soprano and Chamber Ensemble (1957, rev. 1962), by George Rochberg, offers a serial understanding of Blake's art. The structured management of Rochberg's writing becomes oddly Blakean in the most modern sense, creating a distinctly different experience versus the other two cycles.

The heart of the discussion lies in the relationship between text and music in the song cycles of Vaughan Williams, Britten, and Rochberg and how their musical settings affect and enhance the Blake texts. There are unique obstacles in setting the poetry of 
William Blake. For example, most readers' first encounter of Blake's poetry is the Songs of Innocence and Experience. The two sets of poems draw on the culturally understood idea of "innocence" and "experience" existing chronologically in a person's life (as in the movement from childhood to adulthood). Blake's subtitle to the work, "Shewing the Two Contrary States of the Human Soul," contradicts this idea and suggests that "contrary states exist not in linear sequence, but in parallel: they are simultaneous."23 The idea of a simultaneous existence permeates the poetry and fills the seemingly simple language with hidden meaning and opens it to multiple interpretations. In addition to the language, the poems' general structures, singsong rhythmic accents and often strict rhyme schemes, make it difficult to imagine the Songs set to anything but simplistic strophic settings. The sheer number of poems within the collection also creates a problem of continuity. It is fairly safe to say that only one complete setting of The Songs of Innocence and Experience, William Bolcom's gargantuan three-hour work for soloists, choruses, and orchestra that premiered in 1984, can be seen as successful in the classical music world. More often, composers are left to pick and choose, which creates an issue of not only setting poetry intended to be a complete group with interconnections between poems but also with corresponding artistic images. Finally, the wide historical gap encountered by the twentieth century composers who found inspiration in Blake's writing could lead to a misinterpretation of or insufficient cultural understanding associated with Blake's beliefs. However, this is not as troublesome as one might think. Blake's poetry, though widespread and diverse, often deals with universal "truths" and examinations of humanity and human

${ }^{23}$ Jonathan Roberts, William Blake's Poetry: A Reader's Guide (London: Continuum International Publishing Group, 2007), 39. 
nature, making it adaptable to any age. As we will see, selections from the settings of Vaughan Williams, Britten, and Rochberg address the above difficulties in different ways. In beginning to look at the music set to Blake's poetry, a number of questions arise. How do twentieth century musical idioms work with the early or pre-Romantic poetic style of Blake? For example, is the modern style of Britten and Rochberg more or less effective than the folk influenced writing of Vaughan Williams? Does the rearrangement of the poems from the original, carefully constructed volume alter the intentions of the creator or reveal new connections? How do the interpretations differ between composers? (What different aspects of the poetry are highlighted and what compositional techniques are employed?) How, if at all, does the music attempt to portray the visual art included with the original poetry? Is the music reactionary to the poetry or interpretative of the composer (what is the composer's intention: paint an image, represent a symbol, express ideals of the poet, etc.)? And finally, what is the role of the performer in a work where the poetry is so well known as a stand-alone entity? Is it appropriate to incorporate one's own interpretative understanding of the poetry within a self-contained musical piece? The answers to these questions will be addressed through detailed analyses of both the selected poems and musical settings. 


\section{Chapter 1: William Blake}

"As a man is So he sees. As the Eye is formed such are its Powers...To Me This World is all One continued Vision of Fancy or Imagination..."

(William Blake, in a letter to Dr. Trusler, E702) ${ }^{24}$

I.

Today, William Blake is considered to be one of the first poets to write in the

Romantic style. His belief in the importance of imagination, distrust of societal conventions, and focus on nature and spirituality puts him in the company of other English greats, such as Wordsworth, Coleridge, Byron, or Keats. On the surface, however, Blake's life would not be deemed "Romantic" in the epic sense of the term. He was born in London on November 28,1757 , and, with the exception of living three years on the south coast of England, stayed there until his death in 1827. As Jonathan Roberts comments:

He suffered no early bereavements, never joined the army, never left England, never went to university, never went on the Grand Tour [a continental trip of Europe and rite of passage for young men of the time], did not have a string of failed relationships or lovers, didn't take opium, wasn't in France during the Revolution, fathered no children, never became famous during his own lifetime, worked steadily at his profession to support himself and his wife, and died peacefully in (what at the time was considered) old age. ${ }^{25}$

And yet, out of this seemingly normal (dare we say, boring) life, erupts vivid, terrifying, and visionary art. Blake draws inspiration from the everyday: his normal routines of walking down the street, noticing people, entering stores or churches. It is his outlook on society that is translated into his writings and illustrations. The realization that Blake's entire body of work comes from an internal place of retrospection and observation forces one to look

${ }^{24}$ Unless otherwise indicated, all quotations from Blake's works are from E: David V. Erdman, ed., The Complete Poetry and Prose of William Blake (Berkeley and Los Angeles: University of California Press, 2008).

${ }^{25}$ Roberts, $A$ Reader's Guide, 1. 
outward and examine the social and political contexts in which he lived. This brief study of Blake's life, both the socio/politico-environment and his personal beliefs, will not only enlighten the analyses of the selected Songs poems, but also aid in interpreting their accompanying musical settings.

London during the early to mid eighteenth century was governed by two conflicting thought principles: science and logic versus religion and tradition. Isaac Newton's formulation of the laws of motion and gravitation designed the universe into a mathematical pattern. The philosopher, John Locke, had a similar ordered view of the human mind. Locke took Newton's idea of external forces and applied it to our thoughts and actions with the belief that the human mind is, in essence, empty until it is shaped by experiences, sensations and reflections of the two. Locke praised reason and logic over innate feelings, deeming that knowledge, not instinct, was the only acceptable form of humanity. Towards the late eighteenth century, however, societal tensions began to arise between the new "rational thought" and older cultural traditions. For one, where was religion's place within science and logic? In a still predominantly Christian country, it was difficult to accept both Newton's scientific explanation of the universe and the writings and teachings of the Bible. Secondly, Locke's negation of emotions and instincts became increasingly difficult for society to support, believing that reason alone did not offer a sufficient account of the sensibilities of life. As John Beer comments, "the idea that nothing existed beyond them could well give individuals a sense of their own failings and lead to states of depression." ${ }^{26}$ An overall questioning of what it meant to be human and what place tradition had in the changing English culture, permeated young intellectual, artistic,

${ }^{26}$ John Beer, William Blake: A Literary Life (New York: Palgrave Macmillan, 2005), 1. 
and literary thought. It is within this "search for a better way of being human" 27 that we find the life of William Blake.

William Blake, the son of a successful London hosier, had a rather conventional upbringing. His mother provided his early education at home until he attended drawing school at the age of ten. He was then apprenticed to a professional engraver, James Basire, for seven years, where he learned the many technical skills of engraving and etching that would form the basis of his own creative works. Traditionally, Blake would have entered into his father's business, but the willingness of his parents to support Blake's artistic passion attests to their strong family unit. ${ }^{28}$ Blake grew up in a religious (albeit nonconformist) household and his earliest literary influences came from the writings of the seventeenth century English poet and philosopher, John Milton, and the hymns and writings of Isaac Watts, whom Blake would later satirize in his Songs of Innocence and Experience. Milton would remain one of the key influences for Blake in arenas ranging from philosophy through political thoughts and theology. One peculiarity during this time is that, from his earliest childhood, Blake evidently experienced eidetic visions, a "condition in which human perception projects images so powerfully that the perceiver cannot easily tell the difference between them and images in the physical world." ${ }^{29}$ G.E. Bentley, Jr. offers this account of Blake's visions in his biography, The Stranger from Paradise: “When he was four years old, God put his head to the window and set the child screaming...Later, when he was eight or ten, one day as he was walking on Peckham Rye...he saw 'a tree filled with angels,

27 Beer, A Literary Life, 3.

28 Roberts, $A$ Reader's Guide, 3.

${ }^{29}$ Beer, A Literary Life, 5. 
bright angelic wings bespangling every bough like stars'." ${ }^{30}$ It is not difficult to imagine that Blake's visions made it hard for him to fit in with his surrounding society. His powers of perception made the already strict cultural codes of eighteenth century London seem even more tyrannical, which Blake then reacted against in his artistic and literary work.

Blake's London was one of authoritative control. The power of political and religious entities created a life of oppression for many of London's citizens. Poverty was rife within the town: while disease could afflict persons of any status, the law could strike mercilessly against those without class as a cushion. Imprisonment conditions were harsh and unforgiving, with notoriously grim prisons and open gallows where enormous crowds would gather to watch public executions. ${ }^{31}$ Religious views of the time also added to the sense of persecution by imposing the belief of guilt and sin as a "containing power, imprisoning the will, which tried to overcome its urges."32 This description of sin, when paired with the formation of a God who, while favoring those that followed his commandments, was merciless to those that strayed from the righteous path, led to the creation of strict moral codes and fostered a fear of condemnation for one's instinctive actions.

Blake himself briefly experienced the hand of the law when he was taken up in the Gordon Riots of 1780 . The riots began as a response to new legislation broadening the rights of Catholics. The protests quickly became violent, with days of destruction and clashes with police resulting in over 300 rioters killed and 30 more executed thereafter. ${ }^{33}$

30 G.E. Bentley, Jr., The Stranger from Paradise (New Haven: Yale University Press, 2001), 19-20.

${ }^{31}$ Beer, $A$ Literary Life, 4.

32 Ibid.

${ }^{33}$ Roberts, A Reader's Guide, 6. 
Blake apparently crossed paths with the mob unintentionally, but saw "first-hand both the power of mobs to destroy, and the power of the government to subsequently crush and punish those involved in mob action."34 Mob scenes like the Gordon Riots were prevalent and underline the atmosphere of political unrest that existed both nationally and internationally, the most notable examples being the American and French Revolutions.

The ideas introduced by Newton and Locke, among others, became the cornerstone of the Age of Enlightenment, the intellectual movement that dominated the European world of thought and could be seen as the impetus for the revolutions at the end of the century. Enlightenment thinkers centered on reason as the basis for all decisions, declaring themselves independent from outside influences (namely empirical and religious hierarchies). With reason came the ideals of freedom, equality, and tolerance that are embodied in the Declaration of Independence, the Constitution of the United States and the French Revolution's original refrain, Liberté, égalité, fraternité, ou la Mort (freedom, equality, brotherhood or death). Blake had a "complex and often antagonistic" response to Enlightenment ideas because of his general "distrust of monarchy, Church and state, his loathing of Empire and oppressive traditions, and his non-conformist background."35 For Blake, the Enlightenment claim that reason or logic was the only acceptable path to knowledge was simply another form of imprisonment; "a contradiction of human experience...effectively disavow[ing] inspiration, emotion, art, religion, and so on, as valid sources of understanding." 36

\footnotetext{
34 Ibid.

35 Ibid., 12.

${ }^{36}$ Ibid., 13.
} 
Blake was in his early twenties at the time of the American Revolutionary War, with the French Revolution beginning just ten years later. England was at war for most of Blake's life, and the events and images of wartime would influence almost all of his mature works. In "London" from Songs of Experience (1789-94), Blake paints the image of a discharged soldier, graphically connecting his duty to country with suffering and blood ( $3^{\text {rd }}$ quatrain):

And the hapless Soldier's sigh Runs in blood down Palace walls.

(“London," Experience, E25)

He dedicated two entire poetic works to the revolutions in America and France, depicting both events in apocalyptic visions. Blake combines historical facts, persons, and events with mythological, fantastical elements to create a unique narrative of the revolutions. The opening lines of America: A Prophecy (1793) offer a small example of the vivid and often dense language present in the prophetic works. Here, Blake depicts the standoff between English and American leaders with fire and blood (Albion is an ancient name for the island of Britain):

The Guardian Prince of Albion burns in his nightly tent, Sullen fires across the Atlantic grow to America's shore: Piercing the souls of warlike men, who rise in silent night, Washington, Franklin, Paine \& Warren, Gates, Hancock \& Green; Meet on the coast glowing with blood from Albion's fiery Prince. (America: A Prophecy, Plate 5, E51) ${ }^{37}$

Along with reproving the elevation of "reason" above all other knowledge, Blake's unique religious views furthered his departure from Enlightenment ideals and highlight a main difference between him and other intellectual and artistic figures of the day. Although Blake's exact religious affiliation is debated, it is generally understood that he was some

37 See Appendix B for plate. 
form of "non-conformist," referring to the religious groups that had separated from the Church of England during the seventeenth and eighteenth centuries. ${ }^{38}$ In England there is not a separation of church and state, and, in Blake's time, religious and political influence existed almost in parallel. This inseparable nature of politics and religion, paired with his parents' non-conformist religious upbringing, fostered Blake's incredibly personal and unique relationship with religion. It is known that Blake's mother practiced Moravianism, a Protestant denomination, and that their family did not attend a formal church, leaving Blake to his own interpretations of hymns and readings. ${ }^{39}$ Outside their family, the tradition of harsh guilt-driven religious teachings was being met with new groups that attempted to bring the awareness of "God" into Enlightenment ideals. Deism and Unitarianism were two such sects that merged the readings of the Bible with reason and logic. Instead of a belief in the Holy Trinity, these groups opted for a single God (Unitarianism, at that time, went a step further and saw God as a universal force, not a man), and viewed Christ as an enlightened teacher, able to create and present knowledge, but never to work miracles (as were written in the Bible)..$^{40}$ Blake did not identify with most of the religious views of his time, believing in neither the cold, merciless God of tradition (referring both to the fire and brimstone teachings and their political affiliations) or the logical explanations of a world without miracles or divine intervention. Blake believed in an alternative religious perspective where "knowledge could be gained through what he would come to call 'the Poetic Genius' or 'the Imagination'." 41 The imagination and emphasis on individual experiences became a fixture in Blake's principles and he

\footnotetext{
38 Roberts, $A$ Reader's Guide, 4.

${ }^{39}$ Beer, A Literary Life, 5.

40 Roberts, $A$ Reader's Guide, 14-15.

41 Ibid., 15.
} 
connected one's imaginative powers with the ability to create an ultimate world, a true kingdom of God. Blake was not alone in his beliefs, which can be categorized under the "Enthusiasm" movement of the eighteenth century. Enthusiasm is described as a type of religion that, "opposed the religious establishment as in some measure tepid, decadent, or corrupt and advocated a more immediate relationship between the individual believer and God." ${ }^{2}$ The Enthusiast doctrine fostered the belief in modern prophets, who heightened the Bible's imagery of heaven, earth, and hell by filtering the readings through personal experiences and perspectives, essentially justifying visions and stories as truths through the believed divinity of imagination. Though Blake agreed with and was influenced by the Enthusiastic teachings of the day, he would never fully commit to any one particular religion, and his ideas and beliefs remained distinctive and personal throughout his life.

Blake is, ultimately, a man set against traditions. He seems to never go fully one way or another, allowing him to create works that employ a mix of "radicalism, enthusiasm, irony and ambiguity" that reflect the intense political, religious, and social climate of London during the late eighteenth century. ${ }^{43}$ While he appeared to favor the opinions of the revolutionaries over the singular control of a monarchy, the turmoil of war made him resent both positions. Though he seemingly leaned toward Enlightenment ideas of freedom and equality over the unforgiving strictness of religious tradition, the black-and-white view of reason and its condemnation of religion repelled him. And while he generally reveled in

\footnotetext{
42 Ian McFarland, "Enthusiasm", Cambridge Dictionary of Christian Theology, ed. Karen Kilby et al. (Cambridge: Cambridge University Press, 2011), accessed October 29, 2016, http://www.libproxy.wvu.edu/login?url=http://search.credoreference.com/content/entry /cupdct/enthusiasm/0. ${ }^{43}$ Roberts, A Reader's Guide, 17.
} 
the philosophies of Enthusiasm, we see that Blake again rejects labeling and adopts a view of the human psyche that contradicts almost all religious and social movements of his time.

II.

So far, we have examined the political and religious movements that affected Blake's literary style. We know that Blake was an artist who took inspiration from his unique view of the world around him. Two personal events, however, would also shape his persona and become intertwined with his distinct writing style. In 1782 Blake married Catherine Boucher, who would remain his wife until his death. It is evident through biographical writings that they were unusually happy in their marriage and content with each other's company. John Beer cites a passage by William Hayley, a fellow writer and friend of the Blake's, commenting on the relationship between Catherine and William:

Heaven has bestowed on this extraordinary Mortal perhaps the only female on Earth, who could have suited him exactly. They have been married more than 17 years \& are as fond of each other, as if their Honey Moon were still shining - They live in a neat little cottage which they both regard as the most delightful residence ever inhabited by a mortal; they have no servant - the good woman not only does all the work of the House, but she even makes the greatest part of her Husbands dress, \& assists him in his art - she draws, she engraves, \& sings delightfully \& is so truly the Half of her good Man, that they seem animated by one Soul...44

During the early years of their marriage, William and Catherine had a wide circle of friends that included fellow writers and artists as well as higher-class intellectuals who admired Blake's talents. One such couple was the Reverend Anthony Mathew and his wife Harriet, who would have parties to encourage artistic and intellectual discussion. ${ }^{45}$ Although Blake was considered a lower social class than the wealthy Reverend, he was welcomed at their

${ }^{44}$ G.E. Bentley Jr., ed., Blake Records (Oxford, 1969), 106, quoted in John Beer, William Blake a Literary Life (New York: Palgrave Macmillan, 2005), 46.

${ }^{45}$ Roberts, $A$ Reader's Guide, 8. 
home for his conversation and performances, where he would accompany himself on the harp to his own poetry. The Reverend and his circle were so enamored with Blake that they paid for his first published volume, Poetical Sketches (1783). The volume is a representation of Blake's "enthusiastic" response to a wide range of poets from earlier centuries, including Chaucer, Spenser, Shakespeare, and Milton, and it anticipates some of the distinctive features of his later work. ${ }^{46}$ Blake's less-than-favorable attitude toward patronage is evident in the backward-gratitude language of the advertisement for Poetical Sketches cited by Jonathan Roberts:

The following Sketches were the production of untutored youth, commenced in his twelfth, and occasionally resumed by the author till his twentieth year [...] Conscious of the irregularities and defects to be found in almost every page, his friends have still believed that they possessed a poetic originality, which merited some respite from oblivion. These their opinions, remain, however, to be now reproved or confirmed by a less partial public. (E845)

Blake, not surprisingly, felt patronage impinged on his independence and opted for sustaining himself and his wife through working as an engraver, etching plates for paying customers. While he only achieved moderate success, his engraving business allowed Blake to create unique works without the worry of an approving benefactor.

Though not many literary documents exist regarding Catherine's views on their relationship, the accepted devoted nature of their union suggests that they saw eye-to-eye on most subjects. Blake himself, however, has written a good deal about marriage and his liberal view on sexual behavior as highlighted in the lines of the ballad below:

In a wife I would desire What in whores is always found The lineaments of Gratified desire (E473)

${ }^{46}$ Lincoln, introduction, 12. 
Here, Blake not only comments on the desire for pleasure in a partner, but on society's shameful and moral view of sexuality, pairing the words "wife" and "whores," ironically contradicting their related societal connotations. Blake disagreed with the view of sexual desire as sinful. Like all other human experiences, the divine could be found in sexual pleasures and to negate that instinct would be to negate a divine gift. In a quatrain from "Eternity," Blake suggests that pleasure is to be enjoyed in the moment and then left to pass making room for the next moment, highlighting his view of each human experience being equally important and worth celebrating.

He who binds to himself a joy

Does a winged life destroy

But he who kisses the joy as it flies

Lives in eternity's sun rise (E470)

Blake also acknowledges the dark side of sexuality as promoted by the religious and social standards of the time. In one of Blake's most shocking poems, "I saw a chapel all of gold," a scene of penetration is grotesquely vivid:

I saw a chapel all of gold

That none did dare to enter in And many weeping stood without Weeping mourning worshipping

I saw a serpent rise between The white pillars of the door And he forced \& forced \& forced Down the golden hinges tore

And along the pavement sweet Set with pearls \& rubies bright All his slimy length he drew Till upon the altar white

Vomiting his poison out On the bread \& on the wine So I turned into a sty And laid me down among the swine (E467-8) 
The use of animal and non-living subjects removes any sense of relationship or human connection with the serpent and the chapel. The religious connotations emphasize the obscenity of the serpent defiling this holy place. "I saw a chapel" is one of the best examples of Blake's view on the way institutional powers attempt to control and vilify human instinct, which inadvertently transforms the sexual act into a source of "violence and degradation." 47 Finally, in "The Sick Rose" from Songs of Experience, Blake again uses nonhuman subjects to comment on the state of love and sexuality:

O Rose, thou art sick! The invisible worm That flies in the night, In the howling storm,

Has found out thy bed Of crimson joy: And his dark secret love Does thy life destroy.

(“The Sick Rose," Experience, E23)

Here, the rose can be seen as both a natural object of beauty and purity and a literary symbol of love. The image of the worm relates to the serpent of "I saw a chapel" with its connotations both biblical and phallic. Unlike in the previous example from "Eternity," the word "joy" here takes on a negative connotation. Its rhyming with "destroy" and the addition of the adjective "crimson" suggests a shameful pleasure, again commenting on the cultural idea of sex and desire as secret and sinful.

In 1785, Blake and his younger brother, Robert, formed a partnership and began an engraving business together. In 1787, however, Robert, 24 at the time, succumbed to tuberculosis. His brother's death greatly affected Blake (who was only five years older) and his grief changed his literary style. Blake began exploring the human psyche and found that

\footnotetext{
${ }^{47}$ Roberts, $A$ Reader's Guide, 5.
} 
it was not a solitary entity, but changed according to one's physical state. ${ }^{48}$ For example, the mind performing something physical or requiring energy was different than a mind engaged in passive or rational study, which in turn was different than a mind experiencing affection or love. From this revelation, Blake went on to develop his idea of man as a "mental traveler," who, "walking through the world of experience or labouring at his creative work, develops his real 'intellect,' and in doing so discovers true wisdom."49 Blake translates the idea of multiple minds or personae existing in a single person into different (sometimes contradicting) views within his works, making it a key style characteristic necessary to understand and interpret his writings. From this point forward, Blake's fascination with imagination, its appearance through vibrant images both visual and textual, and the evolving mental states of man emerge as the most distinct and recognizable features of his mature works.

His development of illuminated printing during this time allowed Blake to achieve his vision of a full art form where the mind can experience both text and image simultaneously. The method of illuminated printing Blake crafted not only allowed him to integrate text and image on a single plate, but also freed him from the constraints of traditional engraving and assured him the ability to be his own publisher. Because no original etched copper plates have survived, the exact process of Blake's engraving has become a bit of a mystery. Even Blake himself failed to document his technique, and although there are some written explanations in his Notebook of how to perform different engraving tasks, none account for his unique illuminated books. ${ }^{50}$ We do know that Blake

\footnotetext{
${ }^{48}$ Beer, A Literary Life, 32.

${ }^{49}$ Ibid., 33.

${ }^{50}$ Roberts, A Reader's Guide, 75.
} 
owned his own press, which allowed him the freedom to experiment with different techniques. For the purpose of this study, a brief explanation of the probable engraving process will suffice. ${ }^{51}$ Andrew Lincoln describes the process as "relief etching":

The design was probably drawn and painted directly onto the copper plate in an acid-resistant medium. That part of the surface left bare was eaten away when the plate was immersed in acid, leaving the design in relief. The raised image was then inked and printed on an etching press. ${ }^{52}$

We know that Blake was not fond of patronage, so it is not difficult to think he was also distrusting of commercial publishers or anyone acting as a "middle-man" between art and the public. Illuminated printing became a two-fold creation for Blake: artistically, it allowed him to communicate multiple layers within a single plate, and professionally, it accomplished a direct relationship between himself and the public.

We have explored the main contextual and stylistic elements of William Blake and his writing: his innate distrust and apprehension toward authority (political, social, and religious), his praise of human experience and the divine gift of imagination, his belief that the human mind exists in simultaneous states, and his development of a new form of printing. The first major volume that successfully exhibits Blake's stylistic characteristics and illuminated printing technique is the first issue of Songs of Innocence, published in 1789. The following chapter will examine the genesis of the Songs and explore, in detail, the poetic and expressive elements of this renowned work.

${ }^{51}$ A more detailed account of the engraving process of Blake's illuminated books by Jonathan Roberts, pieced together through different biographical accounts, is offered in Appendix C.

${ }^{52}$ Lincoln, introduction, 13. 


\section{Chapter 2: Songs of Innocence and of Experience}

"And I wrote my happy songs

Every child may joy to hear"

("Introduction," Songs of Innocence, E7)

I.

An art song comprises two parts: poetry and music. For proper interpretation and understanding of a particular piece, it is imperative to study both parts equally. When looking at the poetry of William Blake set by the chosen composers, it becomes clear that the poetic foundations are just as important as the visual and literary imagery in the interpretation and expression of the pieces. A discussion of the distinct literary elements employed by Blake is necessary, then, for a complete and informed analysis of the accompanying musical settings.

Blake's Songs of Innocence and of Experience was published as a set beginning in 1794. During his lifetime, the volume was known only to those "lucky enough to own" one of the rare illuminated copies produced by the author himself. ${ }^{53}$ Today, twenty-four original copies of the combined Songs survive, four copies of Songs of Experience, and twenty-six copies of the separate Songs of Innocence exist, not including posthumous replications. ${ }^{54}$ While these totals are higher than any other work Blake published himself, they seem small in comparison with the reputation and notoriety the poems now hold. Price and content may have been reasons for the small number of copies made for the public. Records indicate that the initial volume was advertised at a price of 10 shillings (a half pound in those times) and rose to 10 guineas (worth about 105 pounds) by 1827, the

\footnotetext{
${ }^{53}$ Lincoln, introduction, 9. 54 Ibid.
} 
year of Blake's death..$^{55}$ These prices were expensive when looking at the vast wage discrepancies of the time: on average, a skilled housekeeper or coachman made between $£ 15$ - $£ 26$ annually, independent artisans around $£ 40$, and the middle-class ranging from $£ 100-£ 500$ annual earnings. ${ }^{56}$ The Songs content may also have been a deterrent for potential buyers. Other authors and poets were printing works for children: fairytales, nursery rhymes, religious poems, etc., so Blake was not alone in his endeavor to reach the market of youth. It has been observed by many critics that a comparison can be made between Blake's Songs and other children's books available around the same time, including "collections of hymns for children, such as those by Isaac Watts, Charles Wesley, or Anna Barbauld; educational playbooks such as William Ronksley's The Child's Week's Work (1712); and emblem books such as John Wynne's Choice Emblems...for the Improvement and Pastime of Youth (1772)." ${ }^{57}$ However, the Songs's challenge of traditions (some blatant, some subtle) targeted a niche group rather than the general populace.

Songs of Innocence came first. In 1789, following the death of his brother and his new-found resurgence of belief in the imagination as a divine portal, Blake moved away from the sardonic writings found in his earlier Poetical Sketches (published 1783) and the prose satire, An Island in the Moon (1784), to an "art that was the medium of direct, lightfilled vision." ${ }^{58}$ With a focus on childhood, a time when one's imagination is most accepted and vivid, Blake created poetry rich in rhyme, rhythm, alliteration, and repetition. Around the same time, Blake was introduced to the religious teachings of Emanuel Swedenborg, a

55 Blake, William. The Complete Poetry and Prose of William Blake, 693.

56 "Currency, Coinage, and the Cost of Living," The Proceedings of the Old Bailey: London's Central Criminal Court, 1674 to 1913, accessed November 1, 2016, https://www.oldbaileyonline.org/static/Coinage.jsp.

${ }^{57}$ Lincoln, introduction, 14.

${ }^{58}$ Beer, A Literary Life, 34. 
Swedish inventor and scientist who later turned to religion. Swedenborg's writings, first published in 1784, confirmed many of Blake's beliefs, especially his view of the conception of innocence as an inner state:

...It is evident that all innocence is from the Lord. For this reason the Lord is called in the Word a "lamb," a lamb signifying innocence.

The Lord himself is called a child, or a little boy (Isaiah ix.6), because he is innocence itself and love itself. ${ }^{59}$

Blake echoes these sentiments in one of the most well-known poems from Songs of Innocence, "The Lamb" (second stanza):

Little Lamb I'll tell thee, Little Lamb I'll tell thee: He is called by thy name, For he calls himself a Lamb. He is meek \& he is mild; He became a little child. I a child, \& thou a lamb, We are called by his name. Little Lamb God bless thee! Little Lamb God bless thee!

("The Lamb," Innocence, E8-9)

The idea of innocence in connection with children or child-like mentalities permeates the Songs of Innocence, and Blake portrays the state as both "the condition of man before the Fall" and as "the child who has not yet experienced the inner divisions of human life."60 The Innocence poems focus on joyful and protective relationships ("Infant Joy," "A Cradle Song," etc.), pastoral scenes of content ("Spring," “The Shepherd"), and shared happiness or

${ }^{59}$ Emanuel Swedenborg, Heaven and Hell (New York, 1956), 174; Arcana Ceolestia (New York, 1873), 146, quoted in Morton D. Paley, ed. Twentieth-Century Interpretations of Songs of Innocence and of Experience: A Collection of Critical Essays (Englewood Cliffs, New Jersey: Prentice Hall Inc., 1969), 3. ${ }^{60}$ Morton D. Paley, "Introduction," in Twentieth-Century Interpretations of Songs of Innocence and of Experience: A Collection of Critical Essays (Englewood Cliffs, New Jersey: Prentice Hall, Inc., 1969), 2. 
common identity ("The Echoing Green," "Laughing Song”). Blake's engravings reiterate these sentiments with green fields, flowering vines, and human and animal figures appearing happy and peaceful.

Songs of Experience was written five years after Songs of Innocence and represents a turn in Blake's outlook from enthusiasm to bitterness. The transition from Innocence to Experience for Blake evidently occurred in 1792 with the September massacres of the French Revolution, the execution of some 1,200-1,400 prisoners as a preemptive thought for security. ${ }^{61}$ For Britain, the early part of the French Revolution was met with widespread support, especially among British intellectuals and artists. By 1793, however, with the execution of King Louis XVI, France declaring war on Britain, and the beginning of the Reign of Terror, the British government became "acutely anxious" that the Revolution would spread to England and result in similar violence. ${ }^{62}$ The British government responded by instituting a number of pieces of legislation known as "gagging acts" that attempted to control the output of publications and the organization of public meetings, directly affecting Blake and his engraving business. Blake faced disgust not only with the violent acts occurring in France, but with the oppression and forced regulation of a fearful government in his daily life.

The impetus for creating a contrasting work to Songs of Innocence, then, can be seen as two-fold. For one, Blake, being dedicated to exploring all aspects of humanity, considered it a general response to form a complementary set of writings that contrast with his ephemeral and vivid telling of innocence. Second, the work served as an outlet for his inescapable need to react to the current social and political environment of the time.

61 Beer, A Literary Life, 53.

62 Roberts, A Reader's Guide, 18. 
Like innocence, in Blake's view, experience is an internal state "externalized in a world of images - chain, thorns, spears, graves, briars, blood, and roots — all of which correspond to felt qualities of life."63 If innocence is represented by a comforted and joyful child, experience is seen as an adult, trying to analyze and reason with their feelings, incapable of the spontaneity of imagination and disillusioned by their lot in life. The Experience poems focus on the selfishness of the human heart, both in vengeance and vanity ("A Poison Tree," "The Clod and the Pebble") and love and jealousy ("The Sick Rose," "The Angel"), the oppression of a bound life ("Earth's Answer," "London"), and the hope for a resurrection to escape humanity ("Ah! Sunflower," "The Human Abstract"). The pastoral images of Innocence are replaced with urban wartime gardens. Experience gardens have bare vines and desolate environments creating the sense of an "enclosed space in which the individual, withdrawn from the larger community, cultivates private desires," while the welcoming and joyful children of Innocence are exchanged with dark, elderly figures of repression. ${ }^{64}$ Generally, the Innocence plates are more detailed with fine lines and textures, while the Experience plates are sparser with heavier lines and less detailed surfaces.

At first, the two volumes were originally conceived as separate entities, but were advertised as a single volume in 1794. When Blake combined the two series, he transferred a few poems from Innocence to Experience: "The Little Girl Lost" and "The Little Girl Found" were both originally in Innocence, "The School Boy" and "The Voice of the Ancient Bard" also had appeared in earlier copies of Innocence. These transfers suggest that the boundaries between the two "States of the Human Soul" were not "hard and fast" in Blake's

\footnotetext{
${ }^{63}$ Paley, introduction, 4.

${ }^{64}$ Lincoln, introduction, 10.
} 
view. ${ }^{65}$ The subtitle to Blake's Songs, "Shewing the Two Contrary State of the Human Soul," proposes, then, that the progression from innocence to experience is not only inevitable but, in most ways, necessary. As one grows from a child to an adult, life takes away one's innocence and replaces it with wisdom. Innocence, though seemingly idyllic in its security, can lead to passivity and dependence, while the knowledge that comes with experience gives one independence and insight and encourages the examination of a contrary side to one's self. The combined work offers parallels between the two series that, in turn, helps to highlight their differences: "Innocence poems may be linked to their counterparts in Experience by identical or contrasting title, while visual contrasts reinforce those in the text." 66 It is no doubt that the poems in the collected volume offer a multitude of interpretations and choices. Just as Blake was tempted to transfer poems from one state to another, few of these poems provide clear answers for their readers. More often there exist contradictions and ambiguities under the guise of simplicity, requiring the reader to look deep within to find their own states of enthusiastic innocence and knowledgeable experience.

II.

What makes Blake's Songs so deceptively simple? How does his use of language and form create such penetrating and memorable verses? Though Blake could not be said to write in any one "style," an exploration of the inner workings of his poetry as well as their ties to overarching stylistic ideas proves helpful in answering the above questions. In her essay, "Metrics: Pattern and Variation," Alicia Ostriker compares reading Blake Songs to a Buddhist proverb explaining the three stages of Enlightenment: “When you are

65 Ibid., 17.

66 Ibid., 16. 
unenlightened, mountains are mountains and rivers are rivers. As you approach Enlightenment, mountains are not mountains and rivers are not rivers. When you have achieved Enlightenment, mountains are mountains and rivers are rivers." ${ }^{67}$ Upon a first reading, the poetry is delightful in its simplicity and rhythmic, singsong pattern, reminiscent of a child's nursery rhyme. Then comes the realization that every word, every rhyme, every slight irregularity of stress and meter is not only deliberate, but has a philosophical and symbolic purpose. Yet to fully absorb the poem, one must take the pulled apart analysis and put it back together, unifying the new knowledge with the original surface pleasures - that, in its essence, is the beauty and the difficulty with Blake's Songs.

All of the Songs begin with roughly the same base: simplistic language, short sentence structure, plain stanza patterns, and symmetrical line divisions. One of the most pronounced stylistic feature is Blake's use of repetition and parallel phrasing within the poems. In Songs of Innocence, the following words (or variations) all occur over ten times: bird, child, infant, lamb, laugh, mother, father, and sweet; weep, sleep, and joy appear over twenty times. ${ }^{68}$ The repetitions create hypnotic, mesmerizing patterns: "Piping down...Piping songs...Pipe a song...Piper, pipe..." in the "Introduction," "Merry, merry sparrow...Pretty, pretty robin" in "The Blossom," the "Laughing Song" where the "green woods laugh...the air does laugh...the green hills laugh...the meadows laugh," and the "Sweet dreams...Sweet sleep...Sweet smiles...Sweet moans" of "A Cradle Song." The occurring repetitions are reinforced further with parallel phrasing, creating worlds of unadorned progressions and contrasts: "So I piped...So I sung...So he vanished...And I

${ }^{67}$ Alicia Ostriker, "Metrics: Patterns and Variations," in Twentieth-Century Interpretations of Songs of Innocence and of Experience: A Collection of Critical Essays, ed. Morton D. Paley (Englewood Cliffs, New Jersey: Prentice Hall, 1969), 10.

68 Ibid., 11. 
made...And I stained...And I wrote" in the "Introduction," "by the stream and o'er the mead...I a child \& thou a lamb" in "The Lamb," "Can I see another's woe...Can I see a falling tear...Can a mother sit and hear" in "On Another's Sorrow," among many others. The poetry of Innocence rarely is constructed of anything more complicated than the above examples. The Experience poems have fewer repetitions and parallel phrasing than Innocence, appropriate considering the broader, more diverse mental state of experience. Here, only the words love, weep, and night occur more than ten times, with variations of self, father, hand, and fear following close behind. ${ }^{99}$ The repetitions that do occur are made that much more potent and seem purposeful rather than hypnotic: "Tyger, tyger..." the infamous beginning, "In every cry...In every voice...In every ban" of "London," "a human heart...a human face...the human form...the human dress" of "A Divine Image." The use of parallel phrasing is similar to Innocence, but here the phrases exude more somber reasons for reiteration than the joyful, comforting tones of Innocence.

Both sets of poetry employ short sentence structures and simple stanza patterns. A typical complete sentence in the Songs takes only one or two lines:

The sun does arise,

And make happy the skies; $\quad$ ("The Echoing Green," Innocence, E8)

I have no name; $\quad$ ("Infant Joy," Innocence, E16)

O Rose, thou art sick! (“The Sick Rose," Experience, E23)

Am not I

A fly like thee? ("The Fly," Experience, E23-24)

In longer sentences, Blake employs common lengtheners like "and," "but," "if," and "when," keeping the language simple even in longer thoughts. Not only are the sentences commonly

${ }^{69}$ Ibid., 12. 
brief, but Blake hardly ever uses run-on lines, or the technique of enjambment. Each syntactical unit exists as an intact idea or image, resulting in a "vivid, compact, complete, moment of vision." 70 The Songs then become strings of these moments weaved together, like musical motives in a composition.

The stanza patterns and metrical divisions of the poetry add to the simplistic building blocks of the language. Most commonly, lines are short consisting of four or less feet and stanzas are grouped into quatrains in rhyming couplets (aabb) or alternating rhymes (abab or abcb). Only three out of the nineteen poems in Innocence have lines longer than a tetrameter ("Little Black Boy" in pentameter, "Holy Thursday" in heptameter, and "Spring" written in dimeter with a pentameter refrain). The poems that employ longer stanzas (six out of the nineteen) such as "The Echoing Green," "The Lamb," and "The Blossom" are written in short meters so the moments or images within the poetry are kept succinct and compact. The poems of Experience are even less diverse in meter and stanza length, but have a greater flexibility of stress and accent. Only the "Introduction" and "Earth's Answer," which could be viewed as more abstract in theme and language, use stanzas longer than a quatrain, and the pentameter refrains of "A Little Girl Lost" are the lone lines that are longer than four beats. The self-contained lines and short stanzas encourage a slow reading of Blake's Songs, not allowing one to leap ahead or suspend a thought from line to line, as if "each line affords a finished, if minute, esthetic satisfaction."71

There is a symmetry in the lines that encourages a nursery rhyme or ballad-like rhythm of the poetry. Lines of two or four feet are usually divided in half or not split at all;

70 Ibid., 12.

71 Ibid., 13. 
lines of three feet often contain no pauses. The pattern of evenly dividing a line in half can be found in most of the beginning lines in both Innocence and Experience:

\begin{tabular}{|c|c|}
\hline Piping down / the valleys wild & ("Introduction," Innocence, E7) \\
\hline Once a dream / did weave a shade & ("A Dream," Innocence, E16) \\
\hline Sweet dreams / form a shade & ("A Cradle Song," Innocence, E11) \\
\hline Love seeketh not / itself to please & $\begin{array}{l}\text { ("The Clod and the Pebble," } \\
\text { Experience, E19) }\end{array}$ \\
\hline A little black thing / among the snow & $\begin{array}{l}\text { ("The Chimney Sweeper," } \\
\text { Experience, E22) }\end{array}$ \\
\hline I dreamt a Dream / what can it mean & ("The Angel," Experience, E23) \\
\hline
\end{tabular}

Because of these symmetrical divisions, a reading of one of Blake's Songs innately takes on the regular beat or "thump" of a nursery rhyme. Unlike most poetry, the Songs actually encourage a fixed beat, practically demanding that the reader internalize and celebrate the simplicity and pleasure of symmetrical rhythms.

Why, then, are the Songs so different from the nursery rhymes we have known all our lives? Upon a simplistic, yet strong, foundation, Blake constructs complex worlds of meaning through variations in accent and tempo and his rare, purposeful use of asymmetry. The opening stanza of "The Tyger" offers examples of Blake's variations:

Týgĕr! Týgĕr! búrnĭng bríght In the forests of the night, What immortal hand or eye Cŏuld fráme thy̆ feárfŭl sýmmĕtrý?

(“The Tyger," Experience, E24-5)

"The Tyger" is written in trochaic tetrameter with the pattern of accented/unaccented syllables. The trochaic line is one of three metrical feet Blake employs throughout the Songs. The first three lines can be divided symmetrically with two beats in each segment and seven syllables per line. The third line could be read without a break, but the preceding 
2-beat / 2-beat line rhythms introduced by the strong alliteration of "Tyger! Tyger!" carries heavily into the third line. The fourth line breaks the pattern with a variation in accent and division. Blake switches to iambic meter (unaccented/accented) immediately disrupting the previous steady rhythm and adds a syllable, causing an asymmetrical division. Ironically, the line with the word "symmetry" is the only line so far that is not symmetrical. Blake also introduces a tempo change in the fourth line, furthering its distinction from the first three. So far in the poem, we have heard mostly short, plosive consonant sounds (the t's of "Tyger," "bright," "night," "what"). The third line hints at a change with the longer bilabial ' $m$ ' of "immortal," but the persistent rhythm shadows the elongated consonant. In the fourth line, however, the reader is forced to slow down and pronounce the now accented second syllable and continues to slow with each subsequent ' $\mathrm{f}$ ' fricative. The opening strength and power of the ' $t$ ' alliteration morphs into a softer yet intense (perhaps "fearful"?) repetition of the ' $f$ '. Variations and details such as these are not only evident in the subsequent stanzas of "The Tyger," but are common throughout the Songs of Experience, creating vivid imagery and often ambiguous meaning through subtle literary elements.

As noted above, Blake uses three different metrical feet in the Songs. Iambic meter, among the most standard in English (the usual foot of Spenser and Shakespeare), is reserved for "soberer" pieces: “The Little Black Boy," “The Divine Image," “Holy Thursday,” in Innocence, the moralizing "London," "The Clod and the Pebble," "A Little Boy Lost," and "To Tirzah" in Experience. ${ }^{72}$ Trochaic lines were less popular in eighteenth century English writing, but Blake uses this meter in diverse ways and it appears in almost half of his

72 Ibid., 15. 
Innocence poems and about a third of Experience. Some of the most well-known poems in the Songs are in trochaic meter: "The Lamb," "The Blossom," "The Piper/Introduction," and "The Tyger" among others. The trochee, with its deliberate beginning "downbeat" lends the poetry a child-like or unsophisticated tone. Trochees are usually subject to less variation than iambs, as heard in the abrupt disruption of beat when Blake switched to iambic feet in "The Tyger," and conjure a more "emphatic feeling." ${ }^{33}$ Blake molds the trochee's directness of rhythm into different effects; from child-like naiveté in the Innocence poems to the primitive drum beats of Experience. The third meter that appears in the Songs is the anapest foot (unaccented/ unaccented/accented). Anapests are most commonly associated with sing-song rhythms; they tend to speed up a line and are easily paired with dance rhythms (such as a waltz or polka). Even poets today tend to steer away from strings of anapestic feet. The poet laureate Robert Pinsky, in his guide to poetry, is very frank about the effect of anapests:

The anapest in English tends toward a distinct difference between the two light, more or less elided unstressed syllables and the stressed one; the difference does not seem to vary as fluidly as it can with iambs. The effect of heavier unaccented syllables hustled along, and of many anapests jouncing by one after another, is highly conducive to comedy. ${ }^{74}$

While Blake does not shy away from the cheerful jaunting rhythm of the anapest in his Innocence poems, he darkens it to form "the strangely grave beat of the first 'Chimney Sweeper,' the ironic sprightliness of 'The Garden of Love,' and the terrible, gyring 'Rose

\footnotetext{
73 Ibid., 16.
}

${ }^{74}$ Robert Pinsky, The Sounds of Poetry: A Brief Guide (New York: Farrar, Straus and Giroux, 1999), 61. 
thou art sick' of Experience where the waltz has become a danse macabre."75 The lines below offer examples of the range of usage of anapestic feet in Blake's poetry:

The Sun dŏes ăríse, Ănd măke háppy̆ thĕ skíes.

(“The Ecchoing Green," Innocence, E8)

Whĕn thĕ vóicĕs ŏf chíldrĕn ăre heárd ŏn thĕ gréen

And laughing is heard on the hill, My heart is at rest within my breast

And everything else is still.

(“Nurse's Song," Innocence, E15)

O Rose, thŏu ărt síck!

Thĕ invísǐblě wórm

That flies in the night

In the howling storm,

(“The Sick Rose," Experience, E23)

Ănd I sáw Ĭt wăs fílled with graves, And tomb-stŏnes whĕre flówĕrs shŏuld bé;

And Priests in black gowns were walking their rounds, And binding with briars my joys \& desires.

("The Garden of Love," Experience, E26)

Blake's use of varying metrical feet allows him a great range of expression. The iambic poems are closest to conversational or "normal" speech; the trochaic ones are emphatic, exposed, and unadulterated; the anapestic poems resemble music and its infinite emotions, carrying the reader along in poetic rhythm. ${ }^{76}$

As discussed above, one of the chief characteristics elevating Blake's poetry from plain folk-song or nursery-rhyme is his use of variation. The eighteenth century had a number of rules for writing in the English language. ${ }^{77}$ Blake employs almost every variation known to writers of his time in the Songs. The only major variation that does not appear is

75 Ostriker, "Metrics," 17.

${ }^{76}$ Ibid.

${ }^{77}$ For a list of standard acceptable variations, both minor and major, of eighteenth century English, see Appendix D. 
enjambment, which is logical considering the main construction of lines is based on a single idea or image. We have already discussed Blake's use of asymmetrical division and variation of accent in "The Tyger," but Blake also uses the variation of omitting a syllable in a metrical pattern. A stanza from "Spring" from Songs of Innocence illustrates the technique of variation even within a simple two-foot line:

1 Líttlĕ Lámb

Hére İ́m;

Cóme ănd líck

4 Mý whĭte néck;

Lét mĕ púll

Yóur sŏft Wóol;

Lét mĕ kíss

8 Yóur sŏft fáce:

Mérrǐly̆, Mérrǐly̆, wĕ wélcŏme ín thĕ Yéar.

("Spring," Innocence, E14)

The beat pattern in "Spring" is made up of lines of accented/unaccented/accented syllables, which is created either by an absence of a beginning unstressed syllable or an ending unstressed syllable. On the surface, there looks to be very little room for variation within the primarily monosyllabic words and regular rhythm, but the verse does not read as rigidly as it appears. First, there is variation between the first two lines with the twosyllable word "Little" reading slightly different than the monosyllables "Here I." Second, the adjective "soft" in both the sixth and eighth lines tends to demand more emphasis than the other unstressed words "and," "white," and "me" (in lines 3, 4, and 5 respectively). Blake again plays with tempo and sound duration between the beginning of the stanza, with its crisper shorter consonant sounds "l" and "ck," and the ending lines, with their longer sounds "ft" in "soft" (twice!); the long vowels "oo" followed by "l;" and "s" in "kiss" and "face." The ending refrain again shows a variation on both accent and duration. Here, added unstressed syllables alter the rhythmic feet to form, first, two dactyls (the reverse of an 
anapest, accented/unaccented/unaccented), essentially elongating the initial accented/unaccented rhythm of the stanza-proper and, then, three iambs, which change the stress from the initial to the second syllable of each foot. This five-foot dactyl/iamb refrain is an excellent example of the variations possible by adding just one unstressed syllable to a foot. It effectively separates the line from the rest of the stanza while still keeping a connection to the overall rhythmic fundamentals.

Variations such as the ones discussed above are rampant in the poetry of Songs, and aid in creating each poem's unique world. Others to be discussed in the analysis chapter are Blake's use of spondees (accented/accented) and their specific purpose in "London" and "Ah! Sunflower," changes of internal tempo as a symbol of progress in "The Fly," and the repeated use of mixed meters in "A Poison Tree."

III.

Along with the poetic techniques of writing, a number of eighteenth century Romantic styles and genres are helpful to discuss in connection with Blake's Songs: the pastoral genre and sublime style in writing, and the neo-gothic style of art and architecture. Pastoral is a term commonly associated with Romantic writing and refers to a preoccupation with nature and the depiction of an idealized life in a rural context. ${ }^{78}$ Pastoral pieces often focus on the life of shepherds, and take on special meaning when paired with biblical imagery such as God being depicted as a shepherd (e.g. Psalm 23, "The Lord is my shepherd; I shall not want") or Christ represented as the Lamb of God (John 1:36), "and he looked at Jesus as he walked by and said, 'Behold, the Lamb of God!'." The

${ }^{78}$ Roberts, A Reader's Guide, 25-26. 
merging of Christian and pastoral elements is evident in many of the Songs of Innocence, including "The Introduction," “The Lamb," “Night," "Spring," and “The Shepherd."

Unlike his Romantic contemporaries, Blake does not view the pastoral as a "direct observation of natural phenomena," his "lambs and ewes are symbols."79 Take, for example, the language of Blake's "The Shepherd” compared to a passage from his contemporary, Samuel Taylor Coleridge's “This Lime Tree Bower my Prison” (1797):

How sweet is the Shepherd's sweet lot!

From the morn to the evening he strays;

He shall follow his sheep all the day,

And his tongue shall be filled with praise.

For he hears the lamb's innocent call, And he hears the ewe's tender reply; He is watchful while they are in peace, For they know when their Shepherd is nigh.

("The Shepherd," Innocence, E7)

Behold the dark green file of long lank weeds, That all at once (a most fantastic sight!) Still nod and drip beneath the dripping edge Of the blue clay-stone.

(“This Lime Tree Bower my Prison") ${ }^{80}$

Blake never employs the kind of natural description evident in Coleridge's passage. While both poems are set in outdoor environments, Blake's focus is on the subjects and their interaction rather than the inherent beauty of nature as a source for meaning, as it is for Coleridge.

In connection with the pastoral, a Romantic style perspective important to both literature and art during the eighteenth century was the perception of the sublime. The sublime is anything characterized by "obscurity, difficulty, magnificence, loudness, pain,

\footnotetext{
${ }^{79}$ Ibid., 26.

${ }^{80}$ quoted in Roberts, $A$ Reader's Guide, 26-27.
} 
power, terror, infinity, and so on." ${ }^{\text {81 }}$ Like the pastoral genre, the sublime has ties to religion, especially the idea that one would look to the awesome power and might of nature (mountains, seas, forests, etc.) to encounter God and His divine influence. One of the best examples of the sublime in the Songs is "The Tyger" with its "fearful symmetry," and twisted "sinews of thy heart." Another example, though a bit less obvious, is "The Sick Rose" where Blake pairs natural objects (a rose and a worm) with sublime language and events (the "howling storm" of the night that hides the worm until he finds "thy bed / Of crimson joy" to carry out his "dark secret love"). Like his view of the pastoral, Blake's writing never endeavors to purely illustrate the sublime presence of nature; for him, nature, whether pastoral or sublime, is undeviatingly symbolic.

The engravings that accompany the poetry in Songs of Innocence and Experience can be stylistically related to the Neo-Gothic movement in art and architecture and, perhaps more importantly, as a reaction against Classicism as the dominant artistic style during the eighteenth century. Classicism refers to the opinion that the height of human achievement had been attained by the arts and sciences of ancient Greece and Rome. ${ }^{82}$ It came to represent the style most favored by the court and upper-classes and the "classic" languages (Greek and Latin) were often taught at prestigious primary schools and universities, requiring class and money in order to study the language. While Blake admired classical works, he strongly opposed the cultural dominance of classicism in his own time and identified classicism as not only an empirical philosophy but as an emphasis on rules, reason, tradition, and order (mathematically and geometrically), sacrificing the "individual

\footnotetext{
81 Ibid., 27.

82 Ibid., 31.
} 
'genius' in favour of higher abstract principles." ${ }^{83}$ In the arts and architecture, classicism focused on the geometrical and mathematical order of things. In contrast, Gothic art and architecture gave the appearance of each part or piece of the whole having its own life and purpose. This idea of individual parts coming together to form a greater unit is evident in the complex and "decorative forms" of Blake's printed books. ${ }^{84}$

The idea of contraries within Blake's doctrine of beliefs is the final structural theme of his Songs. It was mentioned earlier that Blake's view of contrary states is that they do not exist in a progression or linear fashion; they are parallel and simultaneous. In his writings, Blake calls into focus society's attempt to gain power by attempting to separate existences through the paired opposites of "good" and "evil." This idea can be directly related to the connotations of "innocence" and "experience." Innocence is associated with purity and goodness, while experience is, in a way, synonymous with sin or the biblical Fall (Adam and Eve's fall from Eden). While the Songs are meant to represent different facets of each state, Blake's other writings explicitly discusses "paired opposites and their moral labels." 85 One of Blake's most discussed opposing states is "reason" versus "energy" ("energy" referring to one's imagination, instinctual thoughts, etc.). Direct comparisons and discussion of the relationship between the two appear in works like The Marriage of Heaven and Hell (1793) and the prophetic The First Book of Urizen (1794), where the two main characters are Urizen (reason) and Los (energy). In The Marriage, Blake comments on society's view of "reason" and "energy" ("alone from" means to "come only from"):

\footnotetext{
83 Ibid., 32-33.

84 Ibid., 33.

85 Ibid., 39.
} 
All Bibles or sacred codes have been the causes of the following Errors.

1. That Man has two real existing principles Viz: a Body \& a Soul.

2. That Energy, called Evil, is alone from the Body, \& that Reason, called Good, is alone from the Soul.

3. That God will torment Man in Eternity for following his Energies.

But the following Contraries to these are True

1. Man has no Body distinct from his Soul for that called Body is a portion of Soul discerned by the five Senses, the chief inlets of Soul in this age

2. Energy is the only life and is from the Body, and Reason is the bound or outward circumference of Energy.

3. Energy is Eternal Delight

(The Marriage of Heaven and Hell, plate 4, E34) ${ }^{86}$

Here, Blake encourages the reader to view the body and soul as one being, not to be separated by "good" and "evil," to accept both states simultaneously. Though one cannot fail to notice the title of the plate, "The voice of the Devil," adding a layer of ambiguous irony to the ideas.

Another central idea to Blake's work is that not only are contrary states parallel with each other, they are a necessity to existence: "dark and light, innocence and experience, heaven and hell, tall and short, buyer and seller, and so on." ${ }^{\prime 7}$ Neither exists without the other and, in correlation, to attempt to unite them would cause their ruin. To unite "day and night, dark and light, earth and water, would be to undo the world." 88 Blake's view is that society (or the powers of society) attempts to either reconcile two contrary states or to separate them with labels of "good" and "evil," thus creating a basis for oppression and social injustice. Dividing the world into "good" and "evil" allows society to make moral judgments easily and confidently and, as Jonathan Roberts points out, "it is

\footnotetext{
${ }^{86}$ See Appendix B for plate

${ }^{87}$ Roberts, $A$ Reader's Guide, 42.

88 Ibid.
} 
easier to act in a black-and-white world than in a world of shades of grey; in the face of definite good or evil, than in situations that seem morally equivocal." ${ }^{\prime 89}$ And yet, that is exactly what Blake is challenging one to do; encouraging readers to be open to opposing states. He offers examples and demonstrates through his writings the many moral interpretations and perspectives by which to view the world. The idea of contrary states, their simultaneous existence in the human psyche, and the challenge to embrace a world of "grey" are among the prime reasons the writings of William Blake saw a resurgence in the mid-twentieth century and resonated with intellectuals and artists spanning all genres and styles.

${ }^{89}$ Ibid., 45. 


\section{Chapter 3: Blake's Legacy}

"[T] he voice of Blake...is the voice I have now"

(Allen Ginsberg, "Notes" 28, 1975) ${ }^{90}$

I.

One of the inherent beauties of poetry is its ability to adapt to changing times. This adaptability is a consistent characteristic, whether the words were written twenty years ago or two hundred. When reading poetry of the past, one is not necessarily transported to a different time, but is experiencing the words through a personal, modern lens. Not only is the reader's unique personal journey informing their reading of the poem, but also everything that has transpired culturally since the time the poetry was written (historically, artistically, literary, etc.). When studying or analyzing poetry from a different era than one's own, the research includes not only the environment in which the poetry was written, but also how the poetry and poet are viewed in contemporary times. This research is compounded again when analyzing poetry in relation to art song settings. Now, not only is one studying the poetry and poet, but also the composer: both their relationship to the text and their unique cultural and artistic environment. In this particular case, the analysis and interpretation of eighteenth century poetry set by twentieth century composers is discussed through a twenty-first century lens. This quasi-conundrum requires an added level of exploration into how William Blake is not only viewed today, but also the path this view took over the centuries.

${ }^{90}$ Allen Ginsberg, "Notes," 28, quoted in Peter Otto, "'Rouze up 0 Young Men of the New Age!': William Blake, Theodore Roszak, and the Counter Culture of the 1960s-1970s," in Blake 2.0: William Blake in Twentieth-Century Art, Music and Culture, ed. Steve Clark, Tristanne Connolly and Jason Whittaker (New York: Palgrave Macmillan, 2012), 27. 
During his lifetime, William Blake did not experience the popularity or successes seen by some of his artistic contemporaries. In England, at this time, there was a separation between "artists" (painters, sculptors, etc.) and "craftsmen" (like engravers), the former were considered "inventors," while the latter's purpose was to simply copy or reproduce. ${ }^{91}$ Never having been to a proper university and remaining a professional engraver throughout his life (instead of a painter, writer, artist, etc.), Blake was not considered in the same social position as contemporary poets such as Byron, Shelley, Wordsworth, and Coleridge; therefore, his work was not viewed in the same way. ${ }^{92}$ Blake was not offered any public outlets in which to present his work; his only options were through patronage (which we know he scorned), self-publishing, or private exhibitions. Blake held only one private exhibition: in his brother James's shop in 1809-10. He exhibited three rooms of pictures (about 16 pieces), and wrote an accompanying program entitled $A$ Descriptive Catalogue, which offers not only descriptions of the pieces, but commentary on the merits of Blake's own work against the faults of other major artists. ${ }^{93}$ For example, Blake discusses one of his pieces in relation to the painting technique of Ruben and Rembrandt:

The character and expression in this picture could never have been produced with Ruben's light and shadow, or with Rembrandt's, or any thing Venetian or Flemish. The Venetian and Flemish practice is broken lines, broken masses, and broken colours. Mr. B's practice is unbroken lines, unbroken masses, and unbroken coulours. Their art is to lose form, his art it to find form, and to keep it. His arts are opposite to theirs in all things. (E537)

Much of the catalogue reads as egotistical and vain, as the above example shows, and contains comments on Blake's understanding of how the artistic world views his engraving

\footnotetext{
${ }^{91}$ Roberts, $A$ Reader's Guide, 80.

92 Ibid.

93 Ibid., 81.
} 
as a "lower" art form and the refusal of the Royal Academy and the British Institution to exhibit his work:

I therefore invite those Noblemen and Gentlemen, who are its Subscribers, to inspect what they have excluded: and those who have been told that my Works are but an unscientific and irregular Eccentricity, a Madman's Scrawls, I demand of them to do me the justice to examine before they decide. (E5267)

Needless to say, Blake's exhibition was not met with the highest of praises from contemporary critics. Throughout his entire artistic life and even some time after his death in 1827, Blake's audiences were restricted to a limited number of fellow artists and collectors who remained steadfast in their belief of his genius.

From the year of his death through most of the nineteenth century, Blake's memory was left to a few mentions in biographical studies of English artists. At the end of the nineteenth century, however, two notable poets would have an influence on Blake's reception and subsequent resurrection: Walt Whitman (1819-92) and William Butler Yeats (1865-1939). Whitman's writing prompted a comparison to Blake and an introduction of the eighteenth-century poet as an "Eastern Mystic" in the first full critical essay on Blake's work by Algernon Swineburne, William Blake: A Critical Essay (1868). ${ }^{94}$ Yeats, in collaboration with another poet/painter, Edwin J. Ellis, produced an edition of Blake's collected works in 1893, which included a biography and an essay on "The Symbolic System," viewing Blake in an occult or mystical light. ${ }^{95}$ Other critical volumes would follow, some focusing on his prophetic abilities and symbolism, some on his political activism, and others on his esoteric view of society. Each new examination of Blake's work would help

\footnotetext{
94 Ibid., 87.

95 Ibid., 88.
} 
launch him into intellectual and artistic circles of the time, reaching a zenith in popularity beginning in the 1950 s.

A number of new editions and critical writings on Blake emerged in the '50s and '60s, making his work more accessible than ever to the general populace. The Complete Writings of William Blake edited by Geoffrey Keynes (1957) and The Complete Poetry and Prose of William Blake edited by David Erdman (1965) are two editions still widely used today. Around the same time, three important works of Blake criticism were also published: Northrop Frye's Fearful Symmetry (1947), David Erdman's Blake: Prophet Against Empire (1954), and Kathleen Raine's Blake and Tradition (1968). ${ }^{96}$ These volumes were among the first to assess Blake's works as crucial cultural resources rather than simply archaic, complex English poetry. Blake's works soon saw a boom in popularity that spread well beyond the university and poetry circles into almost every aspect of popular culture: from writing and visual arts through music, theater, and film.

II.

One of the main currents that championed Blake was the counterculture movement of the 1960s. The American counterculture of the '60s goes far beyond the stereotypical images of flower-children, beat poets, hippies, and psychedelic drugs. It was born out of aversion: to hierarchy, to traditions, to the destruction of our environment, and to the call for unity and uniformity that came after two devastating world wars. The counterculture's history can be traced through the popular writings of the time beginning with a look back to two great writers of the nineteenth century: Ralph Waldo Emerson and Whitman, whose

${ }^{96}$ Peter Otto, “'Rouze up 0 Young Men of the New Age!': William Blake, Theodore Roszak, and the Counter Culture of the 1960s-1970s." in Blake 2.0: William Blake in TwentiethCentury Art, Music and Culture, ed. Steve Clark, Tristanne Connolly and Jason Whittaker (New York: Palgrave Macmillan, 2012), 27. 
call for "energetic individualism, a return to nature, a faith in fraternity and equality, and a vehement but heterodox spiritual intensity" had an impact on the youth of the nation and sparked an adaptation of Eastern religions and beliefs into modern American surroundings. ${ }^{97}$ Following World War I, writers like F. Scott Fitzgerald and Ernest Hemingway continued the rebellious ideals prompted by the writings of Emerson and Whitman and rejected American values as materialistic and small-minded. ${ }^{98}$ These developments and ideas were heightened after World War II where new movements in art, music, and writing appealed directly to the youth. The artistic and social movements "put their stress on energy, spontaneity, improvisation, and personal authenticity" and are exemplified in the work of musicians, painters, writers, and actors:

This wave of innovation embraced the bebop virtuosity of jazz musicians like Charlie Parker; the abstract expressionism of such painters as Jackson Pollock; lyrical novels and poems by J.D. Salinger, Jack Kerouac, Gary Snyder, and Allen Ginsburg; youth movies such as Blackboard Jungle and Rebel without a Cause; sensitive "method" acting by Marlon Brando and James Dean; and erotically charged rock music of Chuck Berry, "Little Richard" Penniman, and Elvis Presley. ${ }^{99}$

A number of social and political events occurred in the 1960s that greatly affected the youth culture. Political outrage and disgust during the Vietnam War lead to protests and demonstrations especially on college campuses. The birth control pill was introduced in 1962, creating a culture of free love without inhibitions. The use of marijuana and LSD became widespread as a promise of "nirvana or salvation" and the rock music of artists such as Bob Dylan, the Beatles, the Rolling Stones, and the Grateful Dead became the "oral

${ }^{97}$ Morris Dickstein, "Counterculture," in Encyclopedia of American Studies, ed. Simon Bronner (Maryland: Johns Hopkins University Press, accessed November 4, 2016. http://www.libproxy.wvu.edu/login?url=http://search.credoreference.com/content/entry /jhueas/counterculture/0.

98 Ibid.

${ }^{99}$ Ibid. 
poetry" of the younger generation. ${ }^{100}$ The term "counterculture" would be applied in retrospect toward the end of the decade by Theodore Roszak, who became the spokesman for the movement with his doctrine, The Making of a Counter Culture: Reflections on the Technocratic Society and its Youthful Opposition (1969). Roszak's volume serves as a representation of the shift in human thought during this time from the conventions of the preceding decades to the political activism and visionary characteristics of contemporary youth culture. Though Roszak was not the first to include Blake in his writings on modern society, his work stands out as the most saturated with Blakean ideals and as a basis for the modern view of Blake as a composite figure: as "prophet, poet, cultural critic, visionary, revolutionary, and shaman." ${ }^{101}$

There are two main areas of Roszak's work that highlight the connections between the counterculture's beliefs and Blake's writings: war and government, and theology and religion. Both Blake and Roszak lived at a time of war. Blake's England was at war not only abroad during the American Revolution (1763-1776), but at home during the French Revolution and Napoleonic Wars (1789-1802; 1803-1815). The wars that ravaged Europe during this time are referred to as "total wars," involving the "complete mobilization of a society's resources to achieve the absolute destruction of an enemy." 102 We know that war greatly affected Blake and his writing. He faulted the repressive social culture and the Enlightenment charge to distance the rational self from the instinctual body for producing a civilization capable of "total wars." In the twentieth century, modern equivalents of the technological, political, and psychological advancements seen during Blake's wars reached

\footnotetext{
100 Ibid.

101 Otto, "Rouze up," 27.

102 Ibid., 30.
} 
a new nadir. The destruction of World War II (1939-1945), culminating in the dropping of two nuclear bombs, the Korean War (1950-53), and the Vietnam War (1954-75) serve as backdrops for Roszak's doctrine of thought. For Roszak, along with many others during the 1960s and 1970s, the systems, governments, and people in control were set on the destruction of the natural world; the only source of hope in such a world was a "resurgence of bodily energies" suggested by Blake and realized by Roszak through the counterculture. 103

We know that one of the main ideas in most of Blake's mature works was his search for and celebration of one's imagination and the divine gift found in humanity. Roszak brings Blake's ideas into the modern world and challenges his followers to open their perceptions both internally and externally. In his book, Roszak outlines three axes that create a counterculture mind. The first axis is described as a "continuum of thought and experience" that we can imagine as moving from right to left, where right is "reason" and left is “imagination." In Roszak's words: "as we move along the continuum we find sociology giving way steadily to psychology, political collectives yielding to the person, conscious and articulate behaviours falling away before the forces of the non-intellective deep."104 This sentence gives way to the second axis, envisioned as moving north to south, where one can reach down into the depths of the body, into instinct, spontaneity, and childlike innocence (the "non-intellective deep") and up into the magnificence and infinity of imagination. ${ }^{105}$ The third axis moves back and forward in time allowing one to reach a

103 Ibid., 31.

104 Theodore Roszak, The Making of a Counter Culture: Reflections on the Technocratic Society and its Youthful Opposition, rev. ed. (Berkeley and Los Angeles: University of California Press, 1995), 64.

105 Otto, “Rouze up," 35. 
collective past. Roszak describes going back past ancient times to the "Neolithic village" and its shaman, who Roszak declares as an all-encompassing being for the people: "He was besides being artist, poet, dramatist, dancer — his people's healer, moral counselor, diviner, and cosmologer." ${ }^{106}$ Roszak and many of the counterculture followers find this shaman in Blake and his writings. For Roszak, the primary purpose of the counterculture movement was to find the path to utopia, a journey to a true enlightenment achievable through imagination and recognition of self. In his words:

To create and broadcast such a consciousness of life entails nothing less than the willingness to open ourselves to the visionary imagination on its own demanding terms. We must be prepared to entertain the astonishing claim men like Blake lay before us: that here are eyes which see the world not as commonplace sight or scientific scrutiny sees it, but see it transformed, made lustrous beyond measure, and in seeing the world so, see it as it really is. ${ }^{107}$

While religion is a major theme in Blake's works, Roszak's counterculture appropriates religion and translates it into modern secular terms. For example, if death ferries one from this world to heaven, the counterculture equivalent is the journey from a closed reality to expansive worldly perceptions; the complexity of God becomes the infinity of potential in the human life and the awesome extremes of nature. ${ }^{108}$ In this context, the counterculture has had lasting effects on society. The belief that we can "shape the subjective world" in which we live (that we all have the ability to be "shamen or shawomen"), and that political change can be effected through "pleasure rather than power" continues to be a force for cultural revolution. ${ }^{109}$ To an extent, the counterculture has found a new home in the technological advances of our day (ironically, something both

106 Roszak, Counter Culture, 243.

107 Ibid., 240.

108 Otto, "Rouze up," 38.

109 Ibid., 40. 
Blake and the counterculture were particularly against), namely the Internet and social media, where alternate realities and expanded perceptions are attainable from a computer screen. While one can argue the historical significance and eventual outcome of the culture of love, expression, and revolution during the mid-twentieth century, the attention to Blake and his writings assured a resurgence that would keep his works relevant, popular, and influential to this day and provide a framework for the musical settings of his Songs by Vaughan Williams, Britten, and Rochberg.

III.

After the creation of a multi-faceted image of Blake during the 1960s and '70s, his work and influence spread rapidly through all genres of artistic expression and all aspects of popular culture. Apart from his obvious influence on the literary arts of poetry and writing, Blakean inspiration can be found in music, theater, film, and even politics. We know from historical and biographical accounts that Blake would perform his pieces in selfaccompanied song, and there are ample mentions of music (particularly melody) in many of his works. But, because none of the melodies Blake composed for his poems survived his death, the musical aspect of Blake's poetry and his relationship with music and musical culture during his life is not met with the same scholarly vigor as his literary and artistic practices. The lack of scholarly attention to Blake's "music" has not hindered his substantial impact on one of the dominant art forms of the twentieth and twenty-first centuries: pop music. There are examples of Blake in pop music from as many different genres as one can imagine: folk, metal, experimental, punk, rock, and so on. Jonathan Roberts cites the 
counterculture's understanding of Blake as a "rebel or radical" who, particularly in the "Proverbs of Hell," “appears to preach a gospel of excess:"110

The road of excess leads to the palace of wisdom

He who desires but acts not, breeds pestilence (plate 7, E34)

(plate 7, E34)

Sooner murder an infant in its cradle than nurse unacted desires

(plate 10, E37)

Roberts goes on to offer numerous examples of songs and albums that both use actual texts from Blake or cite Blake's work as influence or inspiration for their music. He begins his examples with the 1970 album of Allen Ginsberg's settings of Blake's Songs entitled, William Blake's Songs of Innocence and of Experience, whose liner notes can be found in Sparks of Fire: William Blake in a New Age. This volume, an eclectic homage of essays, drawings, and different imaginings of Blake, also has one of the only published copies of a Ginsberg/Blake song: "Spring." Below is an excerpt from Ginsberg's notes, which serves as an interesting and personal account of the kind of inspiration felt in contemporary artists by Blake's work:

The songs were first composed on tape recorder, improvised on pump organ in farmhouse upstate NY in two nights after returning from Democratic Convention 1968 Tear Gas Chicago.

Inspiration began 21 years, half my life ago, living in Harlem, in mind's outer ear I heard Blake's voice pronounce The Sunflower and The Sick Rose (and The Little Girl Lost) and experienced illumination of eternal Consciousness, my own heart identical with the ancient heart of the Universe. ${ }^{111}$

Ginsberg goes on to discuss the details in his hearing of Blake's poetry and the specifics of American poetic tradition as it relates to different poetic techniques. He closes his notes by

110 Roberts, A Reader's Guide, 100.

111 Allen Ginsberg, "To Young or Old Listeners: Notes on the Songs of Innocence and Experience," in Sparks of Fire: Blake in a New Age, ed. James Bogen and Fred Goss (Richmond, California: North Atlantic, 1982), 17. 
offering a "call" to other artists to trust their "Inspiration" and continue in Blake's footsteps:

Ma Rainey, Pound, Dylan, Beatles, Ray Charles, Ed Sanders \& other singers have returned language poesy to Minstrelsy. As new generations understand \& decipher poetical verses for gnostic-psychedelic flashes \& practical Artistic messages, I hope that musical articulation of Blake's poetry will be heard by the Pop Rock Music Mass Media Electronic Illumination Democratic Ear and provide an Eternal Poesy standard by which to measure sublimity \& sincerity in contemporary masters such as Bob Dylan, encouraging all souls to trust their own genius Inspiration.

For the soul of the Planet is Wakening, the time of Dissolution of Material Forms is here, our generation's trapped in Imperial Satanic Cities \& Nations, \& only the prophetic priestly consciousness of the Bard - Blake, Whitman or our own new selves - can Steady our gaze into the Fiery eyes of the Tygers of Wrath to Come.

Though such a passionate view of Blake and his necessary impact on modern culture may seem a bit idealistic, the writings of William Blake have undoubtedly taken hold of many pop music and culture individuals. There are entire scholarly essays dedicated to the similarities and relationship between Bob Dylan and William Blake ${ }^{112}$, and the rock group, The Doors, famously got their name from Blake, whom they discovered via Aldous Huxley's mescaline-induced book, The Doors of Perception. ${ }^{113}$

Blake's influence is not limited to the pop culture world. As we have discussed, and will analyze, Blake's writings have inspired composers in the classical realm as well. Arguably one of the best-known musical settings of a Blake work is Jerusalem ("And did those feet in ancient times," from the preface to Milton, 1804-1808) by Sir Charles Hubert Parry, composed in 1916. This piece, written originally for a Fight for Right voting movement, has been adopted by numerous causes and organizations and rose in popularity

112 See "'Only the wings on his heels': Blake and Dylan," by Steve Clark and James Kerry in Blake 2.0: William Blake in Twentieth-Century Art, Music and Culture, pages 209-229.

113 Roberts, A Reader's Guide, 101. 
during the World War years as "something of an alternate national anthem" in England. ${ }^{114}$ The piece has undergone countless arrangements from choral to solo voice to instrumental and remains as one of the most often performed and well-known Blake pieces in England and abroad. ${ }^{115}$ As was mentioned earlier, most of Blake's writings used for song and musical settings are excerpts from larger works (e.g., the song cycles we will be discussing in the following chapter). Few composers have tackled an entire Blake volume and, of those who have, William Bolcom's Songs of Innocence and of Experience, written over a twentyfive year period, stands out as one of the only successful and extensive musical treatments of Blake. The piece relies on an enormous number of musicians and employs an eclectic mix of musical genres to communicate Blake's Songs, serving as an incredible example of the far-reaching and multi-faceted experiences embedded in Blake's writing.

Unlike the literary and musical arts, television, theater, and film naturally quote visual Blake images more frequently than his writings. The often terrifying and grotesque illustrations, particularly those relating to the Fall, the Book of Revelations, and other darker religious subjects, are found in a number of cult films. For example, Sam Raimi's 1981 cult horror film, The Evil Dead, tells the story of five students becoming possessed by spirits after reading a "Book of the Dead" which shows a sketch of Blake's watercolor, The Great Red Dragon and the Woman Clothed in the Sun. ${ }^{116}$ The same picture is mentioned in the novel, The Red Dragon, which was made into two films, Manhunter (1986) and Red

\footnotetext{
114 Donald Fitch, Blake Set to Music: A Bibliography of Musical Settings of the Poems and Prose of William Blake (Berkeley and Los Angeles: University of California Press, 1990), 167.

115 For a listing of arrangements and recordings of Parry's Jerusalem, see Donald Fitch's, Blake Set to Music, pages 167-170.

116 See Appendix B for image.
} 
Dragon (2002). ${ }^{117}$ Apart from the horror and thriller genre, Blake's words are quoted in a plethora of different films. In Bull Durham (1988), Kevin Costner and Susan Sarandon argue over the line "the road of excess leads to the palace of wisdom" quoted above from Proverbs of Hell. The opening lines of "Auguries of Innocence" (in a slightly misquoted form), "to see a world in a grain of sand" (E489), mark the entrance to a cave that helps establish the plot in the 2001 action film, Lara Croft: Tomb Raider. ${ }^{118}$ Finally, Johnny Depp plays a man named William Blake in Dead Man, a 1995 western, written and directed by Jim Jarmusch. Depp does not portray Blake in the film, but uses his name and poetry to "think through themes affecting present-day America."119

The above examples are meant to serve as a sampling of the different genres and areas that found inspiration in Blake's works. Inspiration, however, can lead to appropriation, and as the decades pass since the counterculture thrust Blake's work into the public eye, it is not only radicals and self-proclaimed "anti-institutionalists" like Ginsberg and Dylan who are adopting Blake, but the institutions and authorities he so vehemently despised. Roberts cites three examples that, in light of Blake's beliefs, are so clear and strikingly ironic that they serve great purpose both in this discussion and in the greater arena of social awareness. The first is the 1997 Christmas broadcast of the Queen of England, given the year of Princess Diana's death:

117 Roberts, A Reader's Guide, 102-3.

118 Ibid., 103.

119 Ibid. 
Joy and sadness are part of all our lives. Indeed, the poet William Blake tells us that:

'Joy and woe are woven fine, A clothing for the soul divine, Under every grief and pine Runs a joy with silken twine.'

This interweaving of joy and woe has been very much brought home to me and my family during the last months. We all felt the shock and sorrow of Diana's death."120

The Queen quotes a quatrain from "Auguries of Innocence" (E489). Ironically, however, the monarch of Blake's home country is speaking the words of a proclaimed anti-monarch. Although in this case at least, the words ring true for the occasion, that is not always the case with poetry and prophetic writing that contains so many diverse meanings. The preface to Milton, excerpted in Parry's Jerusalem, is an example of different meanings in different contexts. Parry's hymn is used as a symbol for English patriotism, played during the famous Last Night of the Proms, but also appropriated for the far-right British National Party. ${ }^{121}$ Paradoxically, the hymn also serves as the anthem of the British Women's Institute and is played at English rugby and cricket matches. ${ }^{122}$ One must assume that the meaning of Blake's words differ in each of these contexts, from being called to reform the existing political system to a reinforcement of current societal boundaries, and perhaps differ even from the original function of the words as a preface to a prophetic work. This brings up the question of whether original meaning can (or should) be maintained when much of Blake's work exists in this world as excerpt or quotation. Roberts offers a final

\footnotetext{
${ }^{120}$ Her Majesty the Queen, “Christmas Broadcast: 1997," accessed November 8, 2016, https://www.royal.uk/christmas-broadcast-1997, quoted in Jonathan Roberts, William Blake's Poetry: A Reader's Guide, 103.

${ }^{121}$ Roberts, A Reader's Guide, 104.

122 Ibid.
} 
example in the art holdings and library of 1 Central West End in New York City, owned by Donald Trump. An article written by Mike Goode, "Blakespotting," poses the question of quotation and intended meaning by looking at the use of Blake's words in pop culture:

[T] he penthouse atop Donald Trump's 1 Central Park West complex boasts a "Library Dining Room" that features framed proverbs from The Marriage of Heaven and Hell, including "The road to excess leads to the palace of wisdom" and "You never know what is enough unless you know what is more than enough."123

Goode focuses on the range of contexts in which the two lines from the Proverbs of Hell section of The Marriage are used and the difficulty in defending intended interpretations when the quotations are separated from their original dwelling:

Given such varied invocations of Blake's proverb, one critical impulse is to try to show how they do violence to the proverb, how they uproot it from its historical and textual contexts to endorse ideologies inconsistent with the politics of The Marriage of Heaven and Hell, with Blake, or with 1790s British radicalism. Some version of this historicist impulse prompts our raised eyebrows or provokes our laughs when the radical anticapitalist Blake is apprenticed to endorse the Trump lifestyle. Yet it is difficult to defend the position that the proverb, once dislocated from Blake's copperplate and relocated onto the gilded walls of a luxury penthouse, cannot mean what Trump seems to want it to mean there. ${ }^{124}$

In a world of Internet memes and Twitter accounts, one is all too familiar with the use of quotations and excerpts to serve immediate ideological purposes. The question posed by Goode in his 2006 article of whether or not a quotation retains its original intention remains unanswered and, at times, appears to not matter to a social media public who favors instant visceral reactions over historically nuanced interpretations. The complex and polarizing discussion of cultural appropriation and intended interpretations of excerpted quotation is out of the scope of this study. However, it is important to

123 Mike Goode, “Blakespotting," P M L A 121:3 (2006): 769. 124 Ibid., 770. 
recognize the environment in which Blake is living today in order to better understand the artistic atmospheres surrounding the composers and their cycles discussed in the following chapters. 


\section{Chapter 4: The Composers and Their Cycles}

"The magic power that dwells in music and poetry has the ability ceaselessly to transform us."

(Dietrich Fischer-Dieskau) ${ }^{125}$

Art song grew out of a rich tradition of verbal and musical storytelling. As

mentioned earlier, song is a synthesis of two stand-alone arts, poetry and music. What sets art song apart from other vocal genres, such as opera, musical theater, oratorio, folk song or popular music, is the quality and deliberateness of the synthesis. The poetry of an art song existed before the song was written, differing from other vocal genres such as opera and musical theater where lyrics are written with the specific purpose of setting them to music. Often there is collaboration between composer and lyricist, with some pairs so recognizable that their music is identifiable as teams: Gilbert and Sullivan, Rogers and Hart, Lerner and Loewe, George and Ira Gershwin, etc. Because in an art song the words are conceived separately from the music, the poetry (or prose) could come from any time period and any literary genre. It is the composer's reaction to or interpretation of the words that then becomes the music. ${ }^{126}$ In the classical music world, one speaks about art song as a "setting" of the poetry. The word "setting" exists in different connotations. It can refer to an environment or surroundings, an action of a person or thing (to "set" something), a mounting of a gemstone, or a group of materials (such as china, silverware, etc.). If one ponders long enough, a musical "setting" can evoke all of the mentioned meanings. An art song can conjure specific surroundings and moods, it can place or ground

125 Dietrich Fischer-Dieskau, The Fischer-Dieskau Book of Lieder, chosen and introduced by Dietrich Fischer-Dieskau, with English trans. by George Bird and Richard Stokes (New York: Limelight, 1995), 28.

126 Carol Kimball, Art Song: Linking Poetry and Music (Milwaukee, Wisconsin: Hal Leonard, 2013), 17. 
the poetry for the listener, it can create a precious moment for the words, and it can combine elements to form a "whole" interpretation of a poem. It becomes apparent, then, that an art song's purpose is not to simply accompany words, but to set them in every connotation of the word: "to compose the words - to surround and envelop them in such a way that both their sound and their meaning become part of the musical texture itself."127 Music and poetry are implied sister arts and there are similarities in the reading (silent or voiced) of a poem and the composition and performance of an art song. Lawrence Kramer states that a "song, we might say, does not use a reading; it is a reading, in the critical as well as the performative sense of the term."128 The elements of a song transform words through the control and immediacy of music: their meter and tempo, their rhythms, their melodic contours, and their climaxes. Performers then communicate this converted text, layering another unique interpretation onto the original poem. Edward T. Cone suggests that poetry exhibits "different forms depending on the aspect the reader considers as most important;" like music, the interpreter constantly makes decisions about "speed, emphasis, tone, accent, and inflection." ${ }^{129}$ He goes on to say that a written poem has almost an infinite number of interpretative, which are then amplified with the ability of the reader to move backward and forward in time (hovering over a word to clarify connotation or rereading lines to better connect syntax). In music, however, one is tied not only to the exacting musical elements of tempo, form, melody, etc., but also to the passing of time which forces one to follow a piece through from beginning to end. ${ }^{130}$ The performers must

127 Edward T. Cone, "Music a View from Delft," in Music: A View from Delft, ed. Robert P. Morgan (Chicago: University of Chicago Press, 1989), 19.

${ }_{128}$ Kramer, Music and Poetry, 127.

129 Ibid., 118-119.

130 Ibid. 
communicate with the audience through a single moment and the listeners must get all the information they can from a single hearing. Poetry, then, has much greater flexibility of interpretation, but music, with its connection to time, creates more vivid and immediate responses to the words. These responses are created through musical imagery, which composers build with melodies, harmonies, and rhythms. Every composer has a different approach to setting poetry, but each is after the same goal of communicating an interpretation through a musical framework that evokes concentration and emotion from a listener. Each of the three composers in the study have different specific attitudes towards their music, but all offer important insight into the power of music, the significance of history in their compositions, and the need for personal expression. By briefly examining the composer's musical principles and styles, as well as circumstances surrounding their Blake cycles, a broader understanding of the unique compositional choices and common interpretive goals highlighted in the chosen settings can be reached.

\section{Ralph Vaughan Williams and Ten Blake Songs}

The composers chosen for this study not only exhibit different compositional methods, but have different relationships with the genre of art song. Ralph Vaughan Williams remains one of the most important English composers of the twentieth century, not only because of his distinguished oeuvre of nine symphonies, four complete operas, a multitude of works for chorus and orchestra, and over 150 art songs, but also for his study of and focus on English folk music and his commitment to music's place in the community. Vaughan Williams had an unusually long career of successes beginning with his first published piece, "Linden Lea," in the musical magazine, The Vocalist, in 1902 and continuing for the remaining fifty-six years of his life. While he originally gained 
recognition as a composer, Vaughan Williams was also considered a "folksong collector, musical editor, teacher, conductor, music historian, polemicist, and administrator." ${ }^{131} \mathrm{He}$ was an avid writer and lecturer and his views on music and its connection with English history and culture had a profound effect on musicians, historians, and culturists alike. In a brief article written for the Royal College of Music Magazine in 1912, Vaughan Williams presents the idea of art and music as beginning with one's home culture: “...for though his appeal should be in the long run universal, art, like charity, should begin at home. If it is to be of any value it must grow out of the very life of himself, the community in which he lives, the nation to which he belongs." ${ }^{132} \mathrm{He}$ also encourages the importance of personal expression versus imitation in composition and the source of inspiration coming from life, not study:

Have not we all about us forms of musical expression, which we can take and purify and raise, to the level of great art? For instance, the lilt of the chorus at a music-hall joining in a popular song, the children dancing to a barrel organ, the rousing fervour of a Salvation Army hymn, St. Paul's and a great choir singing in one of its festivals, the Welshmen striking up one of their own hymns whenever they win a goal at the international football match, the cries of the street pedlars, the factory girls singing their sentimental songs? Have all these nothing to say to us? Have we not in England occasions crying out for music? ...The composer must not shut himself up and think about art, he must live with his fellows and make his art an expression of the whole life of the community - if we seek for art we shall not find it. ${ }^{133}$

This focus on national musical inspiration and culture becomes a doctrine continued throughout the composer's career. Vaughan Williams himself had a rather continental study of music. He was a student of Englishmen Hubert Parry and Charles Villiers Stanford,

131 David Manning, introduction to Vaughan Williams on Music (New York: Oxford University Press, 2008), ProQuest ebrary, 3.

132 Vaughan Williams, "Who Wants the English Composer?," in Royal College of Music Magazine, 9/1 (1912), 11-15, in Vaughan Williams on Music, 40.

133 Ibid., 41. 
but also studied with Max Bruch in Berlin (1897) and Maurice Ravel in Paris (1908). ${ }^{134}$ His style absorbs the various formal and stylistic conventions of Western art music and combines them with national folk idioms to create a unique musical personality. During the early 1900s, Vaughan Williams was a member of The English Folk Song Society and actively worked to collect the indigenous music of rural England. Lectures and articles regarding folk music are spread fairly evenly across Vaughan Williams's professional life, indicating that though his active period of song collection lasted only until 1913, the impact of his time in the "folk-song movement" continued until his death. ${ }^{135}$ Vaughan Williams believed that folk-song was the germ for all musical creativity. In a lecture entitled "English FolkSongs" originally given in 1912 and later revised for publication in 1953, he offers this view on folk-song:

This, then, is the folk-song - a spontaneous, unself-conscious, unwritten musical utterance, limited in its scope, it is true, but, within its limits, often of supreme beauty, and containing in embryo all those principles which are at the basis of the fully developed art of music. ${ }^{136}$

It is this connection between the national music of one's history and the place music has in one's community that permeates Vaughan Williams's song style. As mentioned before, this style can be described as embodying a simple complexity, which is generated by "complex structures from elements that are in themselves extremely simple and easy to assimilate...with apparent spontaneity and minimal recourse to traditional patterning or

\footnotetext{
134 Kimball, Song: A Guide to Style and Literature, 312.

135 David Manning, introduction, 7.

136 The first version, published in The Music Student, 4/6-11 (1912) was devised from a lecture given at the Vatican Conference on Musical Education, January 10, 1912; revised version in Percy M. Young, Vaughan Williams (London: Dennis Dobson, 1953), 200-17; in Vaughan Williams on Music, 193.
} 
elaboration." ${ }^{137}$ His melodies reign supreme in his song settings and are complex, but not complicated, and often contain modality and melismatic passages. His harmonies are accompanimental, but not boring, combining both nationalistic and folk elements with more modern musical idioms. Rhythms again embody this simple complexity, which is another continuation of the folk-song language as explained by Vaughan Williams (during a lecture and immediately following a performance of two English folk-songs, one in Aeolian mode and one in 5/4 time):

Now I once heard a very distinguished musical critic [say] he could not understand how an uneducated English countryman could possibly sing in the Dorian mode. He didn't realize of course that these words - modes, 5/4 and so on - are only explanations by scientists, of what is really happening naturally. ${ }^{138}$

The Ten Blake Songs for tenor and oboe are a poignant representation of Vaughan Williams's native folk style. Written in the last year of his life, the sparse textures and exposed nature of voice and instrument create hauntingly beautiful environments for Blake's words. The song cycle was composed for a documentary film commemorating the bicentennial of Blake's birth, The Vision of William Blake, written and directed by Guy Brenton. The cycle premiered in a concert on the BBC on October 8, 1958 with the film premiering publicly two days later. ${ }^{139}$ Ursula Vaughan Williams, Ralph's second wife, writes about the genesis of the Ten Blake Songs in her biography of her husband:

A short job that came Ralph's way was the writing of some songs for a film. The Blake Centenary had suggested a film of Blake pictures, and music

137 Hugh Ottaway and Alain Frogley, "Vaughan Williams, Ralph," Grove Music Online, Oxford Music Online: Oxford University Press, accessed April 18, 2017, http://www.oxfordmusiconline.com/subscriber/article/grove/music/42507. 138 Taken from a transcription of his Howland Medal Lecture held in Yale University Library on December 1, 1954; in Vaughan Williams on Music, 107. 139 Michael Kennedy, The Works of Ralph Vaughan Williams (London: Oxford University Press, 1964), 640. 
was needed for it. The film makers brought screen and machinery and ran the film through and showed Ralph the poems they would like him to set. At first he was not at all enthusiastic. He had always admired Blake as an artist, but he did not care greatly for his poems. However, he said he would see what he could do, stipulating that the songs should not include "that horrible little lamb-a poem I hate."

He had nothing much to do after our carol party, so he considered the poems and decided that it would be interesting to set them for tenor and oboe; it was a match to dry tinder, for no sooner had he decided on the means than the tunes came tumbling out. He wrote nine songs in four days and one morning he said with rage, "I was woken up by a tune for that beastly little lamb, and it's rather a good tune." So he had to set the poem after all. That day Jean Stewart brought her daughters to lunch. They had theirs with Edna our cook-housekeeper, and I had provided some crackers for them. But Edna, who had a great sense of justice, gave each of us a cracker too. When we pulled them, a small pink, plastic lamb fell out of Ralph's. The songs were recorded in January by Wilfred Brown and Janet Craxton, the artists whom Ralph had chosen and to whom they were dedicated. ${ }^{140}$

The explosion of inspiration Vaughan Williams had with the Blake texts harken back to his years of lecturing on the creation of native folk-song: spontaneous, instinctive, and personal. These characteristics are audibly evident throughout the cycle. The ten Blake poems set in the cycle are made up of five poems from Songs of Innocence: (1) "Infant Joy," (3) “The Piper," (5) “The Lamb," (6) “The Shepherd," and (9) “The Divine Image." Four songs are from Songs of Experience: (2) “A Poison Tree," (4) “London," (7) “Ah! Sun-flower," and (8) "A Divine Image" (the first line of text, "Cruelty has a Human Heart" is used as the title in the cycle). The last song, "Eternity," comprises three short poems from Several Questions Answered (E474-475) on the topic of love. In the anecdote above, Ursula Vaughan Williams refers to the cycle as intended for tenor and oboe, but, in the printed score, six of the songs are inscribed with the option of either tenor or soprano with the other four pieces listed for tenor only. There is also a note at the bottom of the first page stating, "The

\footnotetext{
140 Ursula Vaughan Williams, R.V.W.: A Biography of Ralph Vaughan Williams (London: Oxford University Press, 1964), 386.
} 
oboe parts of these songs may, in case of necessity, be played on a violin or (by transposing the songs down a tone) on a B flat clarinet - but neither of these expedients is advisable. R.V.W."141 These flexible voicings and instructions are reminiscent again of Vaughan Williams's commitment to community music making and his art as an "expression of the whole life of the community." By offering adaptations to his composition he is inviting more active participants to partake in his creation even if their means are limited.

The folk idioms are unabashedly obvious in Ten Blake Songs and each song is either completely modal or with slight modal alterations. There are instrumental drones, folk-like melismas, skipping rhythms and triplets, and clarity of text. The melodic lines are mostly syllabic with melismas reserved for specific purpose, for example: the child that speaks to the piper in "The Piper" uses two-note melismas, differentiating between the two speakers and suggesting the child as a heavenly being of inspiration, "London" employs chromatic alternating pitch melismas to delineate stanzas, and falling melismatic passages are present in "Cruelty has a Human Heart" highlighting destructive words in the text ("cruelty," “jealousy," "terror," etc.). The songs have an organic quality about them, growing and building out of simple ideas. The interaction between the oboe and voice varies from conversational to independent and the role of the instrument is often connected to the text. For example, in "Infant Joy" there is a musical dialogue between the voice and oboe, reflecting the supposed dialogue between mother and infant within the poem. The oboe introduces a line and then drones while the voice speaks, creating an atmosphere of simultaneous movement and tranquility. The image of a spritely little lamb is amazingly

\footnotetext{
${ }^{141}$ Ralph Vaughan Williams, Ten Blake Songs: For Voice and Oboe (London: Oxford University Press, 1958), 1.
} 
clear in the independent and moving oboe line in "The Lamb;" the voice seems to sing over the oboe, touching only for brief moments before the lamb/oboe runs off again.

The music of Vaughan Williams's Ten Blake Songs radiates a purity of personal expression and instinctiveness in composition that makes it equally imaginable on the concert stage or out in the rural countryside. The use of folk-idioms brings out the pastoral aspects of Blake's poetry, which, at times, contrasts with the other settings examined by Britten and Rochberg.

\section{Benjamin Britten and Songs and Proverbs of William Blake}

Continuing in the footsteps of Vaughan Williams, Benjamin Britten championed English art music in the mid-twentieth century. He is best known for his "revival of English opera" (beginning with the success of Peter Grimes in 1945), the founding of institutions to ensure the continuation of English music (like the Aldeburgh Festival of Music), and his outreach to a wider audience in an effort to "increase national musical literacy and awareness." ${ }^{142}$ Britten had a special affinity for music and words and wrote extensively for the voice in all mediums: opera, choral works, art song and song cycles, and orchestral and instrumental works with voice. His operas in particular are viewed as the "most important British contribution to that genre in this century." 143 In his introduction to the opera Peter Grimes, Britten discusses his approach to setting text and his suggestion of continuing the work of Henry Purcell:

One of my chief aims is to try to restore to the musical setting of the English language a brilliance, freedom, and vitality that have been curiously rare since the death of Purcell...Good recitative should transform the natural

142 Philip Brett, et al., "Britten, Benjamin," Grove Music Online, Oxford Music Online: Oxford University Press, accessed November 14, 2016, http://www.oxfordmusiconline.com/subscriber/article/grove/music/46435. 143 Kimball, Song: A Guide to Style and Literature, 335. 
intonations and rhythms of everyday speech into memorable musical phrases (as with Purcell) but in more stylized music the composers should not deliberately avoid unnatural stresses if the prosody of the poem and the emotional situation demand them, nor be afraid of a high-minded treatment of words which may need prolongation far beyond their common speech length, or a speed of delivery that would be impossible in conversation. ${ }^{144}$

This idea of setting words not solely based on speech rhythms and syntax is a staple of Britten's song style. His focus is on the amalgamation of music and words, capturing the essence of the poetry through musical expression. Thus, Britten's songs are highly intellectual and involve deep levels of connection between voice and accompaniment, music and poetry. The great pianist and accompanist, Graham Johnson, had this to say about Britten's innate ability to pair words with music, linking Britten's talent with Schubert:

The planning and the composing are part of the same impulse: a directness and simplicity that goes to the heart of the matter, regardless of how sophisticated the resources used to make that journey. This has led to Britten's music being dismissed as 'musical journalism,' the sort of underestimation from which Schubert suffered in his time. The two composers share what has been allowed to only a handful of musical creators: the unfailing ability vividly to translate words into musical terms that seem inevitable.

This aspect of their genius goes beyond mere illustration, it invades the poetry from within and cleaves to it until it is impossible to separate word and tone into their constituent parts...Putting Purcell aside, the worthiness and the undeniable and various beauties of English song are seldom a match for Britten's ability to become the poet's alter ego, each musical gesture a match for verbal imagery that encourages us to experience the poem afresh, as if for the first time. ${ }^{145}$

Britten's connection to music extended beyond his compositions into his personal relationships and public persona. His life-long partnership with tenor Peter Pears greatly

144 Benjamin Britten, Introduction (1945), in The Making of Peter Grime: Essays and Studies, ed. Paul Banks (Woodbridge, UK: Boydell, 1996), 2.

145 Graham Johnson, Britten, Voice and Piano: Lectures on the Vocal Music of Benjamin Britten, ed. George Odam (Aldershot, Hampshire: Ashgate, 2003), 3. 
influenced his vocal writing and wide literary sense. Pears created all of Britten's major tenor roles, from the title role in Peter Grimes to Aschenbach in Death of Venice (1973).146 He helped co-found the Aldeburgh Festival of Music and the Arts with Britten in 1948 (which will celebrate its sixty-ninth season this summer, a testament to the festival's continued success and tradition), and also aided Britten on several song cycles, including picking the poetry for Songs and Proverbs of William Blake.

Britten kept a strong connection to the public through his avid performing. In an interview with Tempo magazine, Britten explains his fondness for performing:

I like performing for several reasons. I enjoy the contact with the audience, and I find it valuable for my activities as a composer to see how listeners react to the music. I also enjoy rehearsals - especially if I am working with sympathetic and intelligent musicians - delving deeper and deeper into the great music of all ages, and learning a lot from it. There are some composer's whose music I do not like, but performing it makes me analyze my reasons for the dislike, and so prevents it from becoming just habit or prejudice. ${ }^{147}$

Britten's gift for writing for the voice has ensured him a special place in song history, not just in England, but around the world. His vocal music is as complex as it is personal and as intelligent as it is instinctive. Many of his most widely celebrated style characteristics and techniques are accentuated in his Songs and Proverbs of William Blake.

The origin of Britten's Songs and Proverbs of William Blake, premiered at the Aldeburgh Festival in June 1965, can be considered a kind of "group effort." It employed the influence and creativity of three artistic and opinionated men: Benjamin Britten, Dietrich Fischer-Dieskau, and Peter Pears. The Songs and Proverbs is the only one of Britten's works

${ }^{146}$ Alan Blyth and Heather Wiebe, "Pears, Sir Peter," Grove Music Online, Oxford Music Online: Oxford University Press, accessed November 16, 2016, http://www.oxfordmusiconline.com/subscriber/article/grove/music/21147. 147 Benjamin Britten, “Conversation with Benjamin Britten," Tempo 6 (February, 1944): 5. 
written for Fischer-Dieskau's voice that is also dedicated to the singer. ${ }^{148}$ On the inside cover of the cycle there are hand-written words of dedication, "To Dieter, the past and the future." 149 This phrase, quite Blakean in nature, serves as both a sad acknowledgement of the death of Irmagard Poppen Fischer-Dieskau in childbirth in 1963 and as hope that "new paths would bring new happiness." ${ }^{\prime 50}$ At the time of the premiere, Fischer-Dieskau was already arguably the world's most famous Lieder singer, though his relationship with Britten (also already well-established) was fairly new. With both men set in their musical ways and opinions, their collaboration was not entirely smooth. ${ }^{151}$ The tension of this uneasy partnership somehow makes its way into Britten's settings of the Blake texts. The elevated nature of the pieces could be seen as a "compliment" to Fischer-Dieskau's musical prowess and the visionary and prophetic nature of the text a possible homage to the singer's "enormous stage personality."152 Britten miraculously infuses these characteristics into the music, creating a cycle that is equally aloof and intuitive.

Peter Pears's contribution to the Songs and Proverbs was his literary prowess. It was Pears who assembled the combination of prose proverbs (taken mostly from the "Proverbs of Hell" section in The Marriage of Heaven and Hell) and poems from, with one exception, Songs of Experience. The outline for the cycle is quite simple: six Proverbs from The Marriage of Heaven and Hell alternate with the same number of poems from the Songs of Experience, followed by the first four lines from Auguries of Experience (listed in the music

148 Graham Johnson, Britten, Voice and Piano, 209.

149 Britten, Benjamin. Songs and Proverbs of William Blake: For Baritone and Piano, Op. 74. New York: G. Schirmer, 1965.

150 Graham Johnson, Britten, Voice and Piano, 209.

${ }^{151}$ For detailed anecdotes regarding the Fischer-Dieskau/Britten relationship, see Graham Johnson's Britten, Voice and Piano: Lectures on the Vocal Music of Benjamin Britten, pages 208-212.

152 Graham Johnson, Britten, Voice and Piano, 211. 
as a seventh Proverb) and ending with the last fourteen lines of that same work. The cycle begins with two poems that comment on the inhumanity of an industrialized civilization ("London" and "The Chimney-Sweeper"), which continues into the malignancy of a human relationship in "A Poison Tree." The subjects turn non-human for the next three poems, moving from the sublimity of "The Tyger," to the flippancy of "The Fly," and the yearning bloom of "Ah! Sun-flower." The subject of mortality and the fleeting nature of time in "Ah! Sun-flower" progresses easily to the final lines from "Auguries of Innocence," where the cycle ends with a realization of the infinite in all things and the Blakean connection between the Divine and humanity. The proverbs act as connecting material between the varying styles of the poem settings, either by comparing, foreshadowing, or commenting on the poetic text and often move seamlessly (via attacca) into their corresponding poems. For example, the first proverb acts as an introduction to Blake's bleak view of the city in "London," listing first all the traits that are then found in the poetry: pride, lust, wrath, and nakedness. In contrast, Proverb V leads the cycle from one poem to the next by way of parallel words and ideas: repeating "tyger," continuing the animal subject matter, and contrasting "wisdom" (in connection with the "tyger") and "folly" (presumably introducing "The Fly"). The sequence chosen by Pears highlights the darker side of Blake's poetry and takes the listener on a journey through the misery of an earthly human existence to a hope for divine release.

Britten's cycle is a tightly woven structure of varying techniques and unifying elements. The ritornello-like proverbs are set in a free-form, recitative style which get progressively more animated throughout the continuous cycle. In the proverbs, the pianist and singer alternate between flourishes and declamatory phrases. The feeling of freedom 
and expansion in the introductory proverbs are in stark contrast to the detailed, measured, and often-dense textures of the poem settings. Britten employs a combination of older and modern compositional techniques throughout the Songs and Proverbs: counterpoint and motivic development often paired with polytonality, modality, tonal clusters, and twelvetone technique. For example, both the opening piano accompaniment and vocal melody of "A Poison Tree" employ a mixture of serial and tonal elements. The piano introduction uses all twelve pitches in a set of four alternating tri-chords in an eighth-note triplet pattern, though the repetition of the triplet pattern and the placement of the pitches into tri-chords rather than clusters gives a sense of polytonality instead of serialism. The opening vocal melody also includes all twelve pitches, but Britten's use of repetition in the starting and ending note creates a "tonal-ish" aural arc to the melody. Amalgamations of stylistic elements like the above examples are rampant through the entire cycle and will be discussed in detail in the following chapter.

The subtitle for Blake's Songs, "Shewing the Two Contraries of the Human Soul," immediately comes to mind when hearing and examining Britten's music. The combination of different style characteristics and compositional techniques can be viewed in direct relation to the idea of a "simultaneous existence" where aspects of a person's life run in parallel, not chronologically. Britten's musical characteristics emphasize the complexity of meaning in the poems and offers settings that are saturated with interpretation, where every chosen element relates to the text or visual image of the poetry. There is little respite from the intricacy and difficulty of the music until the very end of the cycle. As Graham Johnson notes, "The way that the turbulence of this cycle dissolves hauntingly into a gentle major-key triad in the final bar of the postlude is extremely moving...It is little wonder that 
this cycle has long been considered one of Britten's most disturbing and uncomfortable works."153

\section{George Rochberg and Blake Songs: For Soprano and Chamber Ensemble}

George Rochberg was an important American composer, teacher, and essayist of the twentieth and twenty-first centuries. While other composers also often encounter stylistic changes as they mature, Rochberg's musical and compositional journey is one of great interest and individuality. Rochberg's early works showed a strong affinity for the idioms of Stravinsky, Hindemith, and especially Bartok, but by the early 1950s, he had become fully committed to Schoenberg and the twelve-tone method. ${ }^{154}$ His interest in serialism continued until 1964, when the tragic death of his 20-year old son, Paul, prompted Rochberg to completely discard serialism and what he considered its limited and constricting mode of expression. After 1964, Rochberg began to experiment with combining different musical languages in search of universal style, which lead to quotation becoming a central element in his works during the 1960s and 1970s. His Contra mortem et tempus (1965), a chamber work for violin, flute, clarinet, and piano, quotes compositions by twentieth century composers including Boulez, Berio, Varèse, and Ives, "which have been transformed and interspliced, dissected and reconstituted in a daring attempt to renew history by proclaiming in genuinely musical terms the essential unity of past, present, and future."155

153 Graham Johnson, Britten, Voice and Piano, 220.

154 Austin Clarkson and Steven Johnson, "Rochberg, George," Grove Music Online, Oxford Music Online, Oxford University Press, accessed November 16, 2016, http://www.oxfordmusiconline.com/subscriber/article/grove/music/23617.

155 Alexander L. Ringer, "The Music of George Rochberg," Musical Quarterly Vol. 52, No. 4 (Oct., 1966): 410. 
At the heart of Rochberg's experimentation was an innate belief that music was meant for expression. Even his serial pieces were envisioned as expressive entities, not simply technical studies. For example, Alexander Ringer comments on his Twelve Bagatelles for piano (1952) as inspired by Beethoven:

...the Twelve Bagatelles...were conceived as a series of incisive character studies, as if to prove that the technique of composing with twelve tones could serve traditional expressive purposes and did not have to lead necessarily, as some Schoenbergians would have it, to highly involved novel musical structures. ${ }^{156}$

Ringer goes on to explain Rochberg's "individual voice" that had developed and evolved since the Bagatelles:

The genuinely individual voice that spoke first from the Bagatelles has been heard ever since, year after year, with increasing urgency. But, if the voice has remained the same, the language has kept changing, often from one work to the next, always guided by the unflagging conviction that music must never be about sounds only, or for that matter styles and structure, but invariably about man. ${ }^{157}$

Time took on a different meaning after the death of Rochberg's son. He began to "look upon every single moment as a precious gift to be lived and relived."158 Musically, this idea evolved into a concentration on the concept of duration and time as it relates to form: "The articulation of time as process, not of durational segments, is what creates form."159 Rochberg's definition of time is as a "relativistic phenomenon, a dimension measured not by clock but by perception, something whose supposed reality can be defined only by how

\footnotetext{
156 Ibid., 412.

157 Ibid., 413.

158 Ibid., 418.

159 George Rochberg, "Duration in Music," in The Aesthetics of Survival: A Composer's View of Twentieth-Century Music (Ann Arbor: University of Michigan Press, 2010), 67.
} 
it might be experienced." 160 This new "experience" of time, combined with Rochberg's unfailing commitment to music as a vessel for expression, results in a personal style unlike any other. Plainly put, there are no restrictions in Rochberg's music: he can incorporate styles and techniques from every age of music, quotation and inspiration from every type of music, all with the purpose of evoking something within the listener. In the liner notes for the recording of his Third String Quartet (1972), a piece which employs dissonant passages reminiscent of Stravinsky and Bartók and tonal episodes recalling Mahler and Beethoven, Rochberg suggests that his abandonment of "the notion of 'originality'...can only be called a possibility: that music can be renewed by regaining contact with the tradition and means of the past, to re-emerge as a spiritual force with reactivated powers of melodic thought, rhythmic pulse, and large-scale structure."161

The works and writings of George Rochberg serve as an inspiration for composers to this day. His charge for originality through acceptance of history challenges audiences and composers alike to have music "say something." Joan DeVee Dixon begins her book, George Rochberg: a bio-bibliographic guide, with a number of quotations from Rochberg: "(1) because they were too precious to leave out, and (2) so that the reader might more fully appreciate the true artistry, integrity, and thought behind Rochberg's music."162 Among the many pearls of wisdom, one quotation emerges as an embodiment of his thoughts during his musical evolution in the 1960s, the period of his Blake Songs:

\footnotetext{
160 James Wierzbicki, "Reflections on Rochberg and 'Postmodernism'," Perspectives of New Music Vol. 45, No. 2 (Summer, 2007): 119.

${ }^{161}$ Rochberg, liner notes for String Quartet no. 3 (1973), quoted in James Wierzbicki, "Reflections on Rochberg and 'Postmodernism'," 114-115. 162 Joan DeVee, George Rochberg: A Bio-bibliographic Guide to His Life and Works (Stuyvesant, New York: Pendragon, 1992) xxiii.
} 
I have always clung fast to these fundamentals: that music was given man so he could express the best he was capable of; that the best he was capable of had to do with his deepest feelings; that his deepest feelings are rooted in what I believe to be a moral order in the universe which underlies all real existence. (ca. 1963) 163

Rochberg's Blake Songs: For Soprano and Chamber Ensemble were first composed in 1957 and revised for publication in 1961. The four texts are taken from Blake's Songs of Experience: “Ah! Sunflower,” “Nurse's Song,” “The Fly,” and "The Sick Rose." The chamber ensemble comprises flute, clarinet, bass clarinet, celesta, harp, violin, viola, cello, and soprano solo. Each song uses a different combination of instruments and at no time are all instruments used in any one setting. The work was premiered in a concert for the International Society for Contemporary Players in New York City on October 6, 1961 by the Hartt Chamber Players with Shirley Suddock, soprano, and is dedicated: "To my son, Paul."164 Rochberg's notes on the composition offer an invaluable resource for the conception and organization of the pieces:

The Blake Songs attempt to reveal through voice and instrumental color the hidden, below-the-surface aspects and resonances evoked in me by Blake's poetry. The deceptive naiveté of Blake's verbal art is only a thin coating overlaying the dark and potent images he creates - images that appeal directly to the heart.

Each song derives its essential form from its text. The point at which the surface of the form of the music meets the surface of the form of the texts is in the use of "strophe" and "refrain." These songs constitute only a fragment of a larger group of setting of Blake Songs planned by the composer. ${ }^{165}$

The Blake Songs are serial pieces, and, like Rochberg's other serial works, contain many expressive melodic and textural elements that, in this case, directly relate to the text.

163 George Rochberg, quoted in Joan DeVee Dixon, xxvi.

164 Dixon, George Rochberg, 42.

165 George Rochberg, Notes by the Composer, quoted in Dixon, 42. 
His vocal melodies are almost entirely sung pitches for three of the four songs. "The Fly" employs sprechstimme for most of the poetry with sung pitches reserved for important moments in the interpretation. For example, the voice sings "For I dance / and drink and sing," before returning to sprechstimme and is again full voice on the closing line, "Or if I die." Sprechstimme is also used in two instances in "The Sick Rose": first at the end of a descending $7^{\text {th }}$ interval on the first utterance of "sick" and second on the descending $14^{\text {th }}$ of "storm," emphasizing the grotesque connotations of the two words.

As Rochberg mentioned, the form of the pieces are based on the text and all of the songs are set in some arrangement of verse-refrain or ternary structure. The formal sections are dictated by poetic content rather than poetic structure, resulting in asymmetrical divisions. "Ah! Sunflower" is the most evenly proportioned with the form: Introduction - Verse (Quatrain 1) - Interlude - Verse (Quatrain 2) - Postlude, echoing the organization of the written poem. However, most of the sections contain a different number of musical measures highlighting the poetic content versus strict formal symmetry. "The Sick Rose" is written in the same sequence as "Ah! Sunflower," but the lines are grouped as Verse $1(2+4$ lines) + Verse 2 (2 lines) instead of the written two quatrains. Here, Rochberg separates Blake's poem into three distinct events: first is the introduction of the "rose" that is "sick," an image and phrase that Rochberg repeats. Second comes the appearance and atmosphere of the "worm" and its accompanying "howling storm" complete with increased instrumental agitation and faster tempo. Finally Rochberg presents the action of the poem following an interlude and tempo primo, which emphasize the "dark secret love" that ultimately destroys the subject. 
Though Rochberg uses different formal permutations and distinctive instrumental combinations to differentiate between each song, there are also unifying elements connecting the piece as a whole. Three of the four songs use the same twelve-tone row: only the "Nurse's Song" is based on a different row arrangement. The melodies and accompaniments each include all of the usual row transformations (retrograde, inversions, retrograde-inversion) and their transpositions. Sevenths and ninths predominate in both instrumental and vocal motives throughout the four settings. Texturally, the instruments generally alternate single-note and interval conversations with chordal writing layered with obbligato motives. There is no doubt that Rochberg's Blake Songs are extremely complex in terms of the interconnections and transformations of a single tone-row, however, if one examines the piece through an interpretive lens, Rochberg's communication becomes clear. This piece serves as a window into a time in Rochberg's compositional career seldom discussed at length in contemporary settings and is a prime example of the use of serialism for expressive purposes.

All three composers have a different approach to the Blake texts and each of their settings embodies unique aspects of their compositional and personal attitude towards music and poetry. Through the detailed analyses of selected poems from each of the cycles, the similarities and differences in overall poetic interpretation, musical language, and text emphasis will be demonstrated.

The order of the selected poems chosen for analyses poses a problem. None of the composers set their poems in the order of Blake's original series. Upon consideration of both poetic and musical content, an order was devised that would create a progression from external to internal literary substance. A note on the analyses - it is assumed that the 
reader will have full scores available for the in-depth analysis sections; only reductions and comments on pitch content are included in this study. The analysis groups for the following chapter are:

$\begin{array}{ll}\text { POEM } & \text { COMPOSER } \\ \text { "London" } & \begin{array}{l}\text { Vaughan Williams } \\ \text { Britten }\end{array} \\ \text { "A Poison Tree" } & \begin{array}{l}\text { Vaughan Williams } \\ \text { Britten }\end{array} \\ \text { "The Fly" } & \begin{array}{l}\text { Britten } \\ \text { Rochberg }\end{array} \\ \text { "The Lamb" \& } & \begin{array}{l}\text { Vaughan Williams } \\ \text { "The Tyger" }\end{array} \\ \text { "Ah!tten } \\ & \begin{array}{l}\text { Vaughan Williams } \\ \text { Britten } \\ \text { Rochberg }\end{array}\end{array}$




\section{Chapter 5: Analyses}

“London”

1 I wander thro' each charter'd street, Near where the charter'd Thames does flow, And mark in every face I meet Marks of weakness, marks of woe.

5 In every cry of every Man, In every Infant's cry of fear, In every voice, in every ban, The mind-forg'd manacles I hear.

$9 \quad$ How the Chimney-sweeper's cry Every black'ning Church appalls; And the hapless Soldier's sighs Runs in blood down Palace walls.

13 But most thro' midnight streets I hear How the youthful Harlot's curse Blasts the new born Infant's tear, And blights with plagues the Marriage hearse. ${ }^{166}$

We begin with a poem of social criticism. Written in the early 1790s, "London" expresses a bitter indignation for regulation, law, and institution, "set against the distressed cries of individuals." 167 The poem is a string of personal thoughts as the speaker wanders the streets, alternating between the sights (stanzas 1 and 3) and sounds (stanzas 2 and 4) of the city. The lines are seven or eight syllables in length, written mostly in iambs with a change to trochaic stresses in stanza 3, highlighting both the change to individual subjects and the strong language used to describe their plight. Like almost all of Blake's Songs, the syntax is clear, but the interpretation and symbolism (like the use of dual word meanings, for example) is complex.

166 See Appendix E for accompanying plates.

167 D.G. Gillham, Blake's Contrary States: The "Songs of Innocence and of Experience" as Dramatic Poems (London: Cambridge University Press, 1966), 8. 
In the first line, the words "wander' and "charter' $d$ " are set against one another; the aimlessness of the speaker wandering is contrasted with mapped, organized streets: "He has no direction of his own but is led along ways that are obligatory." 168 This introduction immediately separates the speaker from what is going on around him; while he "wanders" the rest of the city methodically bustles. Blake uses the word "charter'd" twice in the first two lines, once to characterize "street" and once to describe the Thames. The word itself has a dual meaning of freedom and of limitation. If something is chartered, it is free to be hired or leased (mostly for travel purposes, as in a charter boat or charter flight), while a charter could also outline and define rights and privileges, essentially limiting freedoms (as in government or corporate documents, e.g. the Magna Carta). To the speaker, in these contexts, both the streets and the Thames represent the hidden constraints of English culture: on the surface, free and open to the public, but not without regulations and laws constraining its uses. Text repetitions play an important role in the first two stanzas and evoke a sense of the inner melancholy of the speaker as he observes his city. Everywhere he looks he sees the "mind forg'd manacles" that man has put on himself. D.G. Gillham explains that Blake's manacles are a result of man's intelligence and industry: "Man has built himself an amazingly elaborate prison by the mind. Too faithless or too clever to rely on the impulse of the moment, he has evolved a system of controls that manage every part of life."169 The speaker recognizes this inescapable weight of proper cultural behavior in "every voice, in every ban."

The last two stanzas turn to specific connections between institutions of church and state and societal victims: "a church that condones brutal child labor, a monarchial state

168 Ibid., 9.

169 Ibid., 10. 
dependent on human sacrifice for its defense, marriage laws that promote prostitution and inheritable venereal disease."170 The imagery in these two stanzas is vivid and gruesome, the language strong and vehement: "black'ning," "blood," "curse," "blasts," "blights," and "hearse." The language is made even fiercer with strong trochaic stresses in the descriptive lines, heightening the emotion from melancholy to disgust at the present situation of the speaker's fellow man. In this portrait of London, every person experiences a degree of social injustice and every institution is an instrument of oppression, from the State to the Church to society's expectation of love.

The act of love is replaced by bleak self-gratification by route of the prostitute. Here the interpretation gets a bit convoluted and difficult. The fourth stanza starts straightforward enough: for the young "harlot," venereal disease is inevitable and that she would transmit that disease to her infant child is also understandable. The last line, however, muddles the outcome: "And blights with plagues the Marriage hearse." At first the statement reads as a natural progression of a contagious disease spreading into the home of the married couple, but the word "hearse" suggests a deeper abhorrence with the institution of marriage and society's strict moral code. If the people of London were able to break free of the prison of moral culture and express individual emotions in an open and accepting environment, perhaps marriage would be based on love instead of duty and expectation and there would be no need for the empty use of prostitutes - perhaps the city could regain a sense of humanity that has been lost in its inhabitants. The poem, however, does not end with such hope, as evident in the speaker's return to the melancholic and resigned iambic meter in the last line. The text presents a bleak picture of

170 Lincoln, commentary on the text and the plates in Songs of Innocence and Experience, by William Blake (Princeton: Princeton University Press, 1991), 193. 
a city where Blake spent most of his life and it is not difficult to imagine that the wanderer could be Blake himself, "the lament his own, and that the condemnation of human muddle contained in the poem is that of the poet."171

The visual image that accompanies the poem does not immediately relate to the intensity of the text. The principal drawing is on the top third of the plate and is a setting of an apparent "midnight" street. A child in green leads an old man in a blue cloak and crutches through a beam of light. "Marks" of "weakness" and "woe" are all too evident in the man's appearance (long white hair and beard) and hunched posture. The shaft of light shows a stone wall, a closed door, and the beginnings of cobblestones to the right of the title. There are a number of contrasting symbols appearing in this top image. Apart from the obvious youth versus age of the child and man, the closed door may indicate a "general lack of pity in this environment," but is juxtaposed with the orange-brown color of the wall suggesting warmth. ${ }^{172}$ The position and attitude of the child is in direct contrast with the tone of the poem. While the speaker has an air of detachment from his observations, the child here appears engaged, innocent, and even protective of his old friend. The cobblestones connect the top image to the text below allowing the lines to flow right into the title. To the right of stanzas 2 and 3 is another picture of a child, this time appearing golden and naked, warming his hands at a glowing fire that billows smoke up to the cobblestones. This child could be a depiction of the chimney-sweeper ${ }^{173}$ mentioned in the

171 Gillham, Contrary States, 14.

172 Lincoln, commentary, 193.

173 Blake's Songs contain a number of images and depictions of chimney-sweepers including two poems entitled "The Chimney Sweeper" in Innocence and Experience. Often orphaned, the working and living conditions of chimney-sweepers during the late 1700s were incredibly deplorable and their plight had a great influence on literature and politics of the time. The Industrial Revolution caused many working-class children to be put to 
text, whose innocence (suggested by the warm gold coloring) is surviving "in the face of woe." 174 The title and text are in warm gold and orange colors and the entire poem is surrounded by a dark green serpentine line of, what seems to be, ivy-like vegetation creeping along from the bottom right corner (with textured lines) along the edge and up the left side connecting to the title. Apart from the naked child warming himself by the fire, the two figures at the top of the page do not seem to be directly drawn from the text and are symbolic in existence. Perhaps there apparent relationship is the humanity and pity that the speaker is subconsciously calling for in the text.

"London" is a poem that highlights the relatable nature of Blake to other, more contemporary, times. The intense, despondent, and bitter poetic images of a city that has lost its way are made that much more believable from the personal nature of the delivery. The language evokes a sense of spontaneity and unfiltered truth, and draws us in as readers, as if we were wandering through the streets right along side the speaker. We see what he sees; we feel what he feels. The visual image reminds us that humanity is still worth seeking. In the darkest midnight hours, there is hope in innocence - we just have to let it guide us.

\section{VAUGHAN WILLIAMS}

"London" is the fourth piece in Vaughan Williams's Ten Blake Songs and is one of the three pieces that are written for voice alone. Along with the a cappella scoring, modality, motivic unity, and a tempo marking of "In free time" emphasize the personal nature of the

work in factories and workshops, and with no parental support, education, or employment regulations. Orphans were at the mercy of whoever would take them in, often being forced to work whatever jobs they could to survive. See, for example, the accounts gathered in Judith Plotz, Romanticism and the Vocation of Childhood (2001).

174 Lincoln, commentary, 194. 
poetry and the isolation of the speaker as he wanders the streets of his city. The fermata in measure 20, along with the varied repetition that follows, divides "London" into two sections: the first section (A) is 20 measures long and consists of stanzas 1 and 2 , while the second section $\left(A^{\prime}\right)$ is 17 measures long and uses stanzas 3 and 4 . The $A^{\prime}$ section is written with the same general outline as the A section with a few noticeable alterations. At the start of $\mathrm{A}^{\prime}$ in measure 20 , the melody begins an octave lower than in measure 1 , creating a wide ascending intervallic phrase from D4 to F5. The effect is three-fold. For one, beginning an octave lower provides a connection between sections (by beginning on the same note as the previous fermata), without which the opening of A' would sound quite jarring. Second, the ascending line acts as a contrast to the meandering ("wandering") beginning of the song and propels the singer into the dramatic intensity of the third and fourth stanzas. And lastly, the ascending phrase (D - E b-F - A) has an effect on the supposed modality of the piece (discussed in detail below). Vaughan Williams generally condenses the phrases in the second section. For example, the second phrase (which encompasses measures 3-6 in section $\mathrm{A}$ ) is only one and a half measures in $\mathrm{A}^{\prime}$ and the third and fourth phrases are similarly shortened, again suggesting the rushed intensity and emotion of the speaker. This condensing of phrases continues up until the last line, where the momentum slows and the full weight of the plagued "marriage hearse" is heard.

Like most of the Ten Blake Songs, "London" employs modality. The myriad of variations Vaughan Williams employs, however, makes the modal analysis more gray than black-and-white. The first four notes of the piece (D - C - A - F) could imply any of three modes (assuming that D is the final of the mode): Aeolian, Dorian, or Phrygian. The introduction of the E b in measure 2 on the second syllable of "charter'd," seemingly 
restricts the piece to Phrygian. However, Vaughan Williams changes to an E natural in measure 4, which suggests that either the Phrygian mode is somewhat variable (with the second scale degree being either raised or lowered) or that the true mode of the piece is $\mathrm{D}$ Aeolian, establishing the $\mathrm{E} b$ as a special musical occurrence. There is musical evidence for each suggestion. The D Phrygian with variable second scale degree argument is made more plausible with the opening phrase of $\mathrm{A}^{\prime}$ in measure 20 , as mentioned above. The ascending scalar passage (D - E b - F - A) strongly points to a D Phrygian modality, which clears up the ambiguity of the opening phrase in measure 1. However, the idea of the $\mathrm{E} b$ as a special musical occurrence is equally arguable when looking at the motivic and cadential elements in the piece. This idea will be discussed in detail below.

Interspersed in the modality are two other musical components: octatonic passages and variable scale degrees used to emphasize text or repeated motives. The first octatonic passage (roughly measures 7-15) is introduced by way of a transition measure beginning with the pick-up to measure 7 on "And mark in every face I meet..." Here, the segment A $\mathrm{A} b-\mathrm{F}$ acts as a transition between modal and octatonic scales by sharing two pitches with each of the larger modes ( $\mathrm{A}$ and $\mathrm{F}$ belong to the $\mathrm{D}$ modal opening and $\mathrm{A} b$ and $\mathrm{F}$ belong to the F octatonic scale). The octatonic scale in this instance is considered to begin with a whole-step, which creates the following collection: F-G - A b - B b - C b - D b - D - E - F. The notes of the octatonic section beginning in measure 7 make up the first half of an $\mathrm{F}$ octatonic scale minus G: F - A b - B b - C b (marked "a" in Example 1). This scale continues ascending through each repetition of "marks," adding D b and D in measure 10 (" $b$ " in Example 1). Vaughan Williams reverses the ascent on the word "woe" with a descending 
motive of alternating whole and half steps to land on a B , a significant event that will be later discussed in detail.

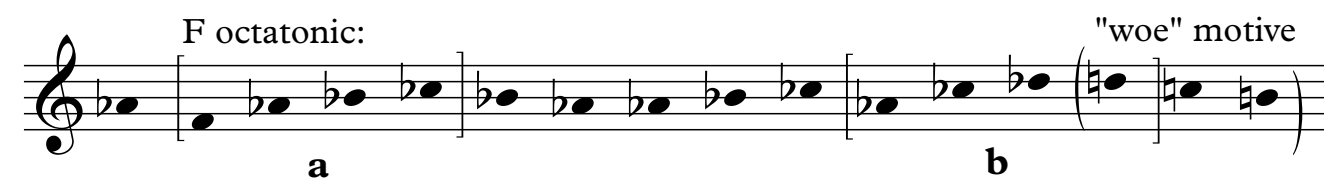

Example 1: Vaughan Williams, “London," measures 7-10 Reduction

Measures 7-10 are sounded again in slight alteration for the next line of text. The ascending line is driven by the repetitions and emphatic rhythmic bounce of "every" in measures 11-15, ending again with the descending "woe" motive on "cry of fear." The G on the first syllable of "every" in measure 15 acts as a mutation point changing to D Phrygian to close the section. Vaughan Williams's specific notation of the word "every" is symbolic and offers one of the most distinctive instances of text painting in the piece. In the poetry, Blake does not cut the word "ev-e-ry" short through elision, like he does the other extra "e's" in "charter'd," "forg'd," and "black'ning." He wants to make sure the reader understands the importance and unification that the word "every" suggests. The speaker is not using the word lightly; literally every "Man," every "Infant," every "voice" is affected by the weight of society. Vaughan Williams effectively conveys this nuance in Blake's writing through the unifying rhythmic motive of "every."

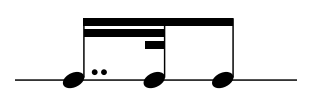

ev - e - ry

Example 2: Vaughan Williams, “London," Unifying Rhythmic Motive on "ev-e-ry”

The second section retains a similar outline, with a measure-long transition to an octatonic passage (beginning with the pick-up to measure 24) and a mutation point (this time on $\mathrm{B}$ b ) returning the piece to D Phrygian for the final cadence. 
With the general musical outline of the piece firmly in place, we will now return to the question of mode, the special musical occurrences of variable scale degrees, and their relation to motives and cadential figures. While there are many repeated musical elements in each section, three motives stand out as being especially helpful in understanding the modal content of this setting of the poem: the three-note descent containing the lowered second scale degree $(\mathrm{E} b$ ) appearing first in measure 2, the alternating half step unit first heard on "flow" in measure 5-6, and the descending "woe" figure first appearing in measures 10-11. Though the "charter'd street" and "woe" motives have similar characteristics, the distinction of the two is the result of their specific functions within the piece and the degree of variation found within each occurrence.

Motives in "London"

\begin{tabular}{|c|c|c|c|}
\hline Motive & Measure(s) & Text & Note Names \\
\hline \multirow[t]{4}{*}{ “charter'd" } & $\mathrm{m} .2$ & charter'd street & $F-E b-D$ \\
\hline & m.16-17 & ban, / The mind- & $F-E b-D$ \\
\hline & m. 21 & sweeper's cry & $F-E b-D$ \\
\hline & m. 32 & tear, / And & $F-E b$ \\
\hline \multirow[t]{4}{*}{ "flow" } & m. 14-15 & flow, & $\mathrm{B} b-\mathrm{A}-\mathrm{B} b$ \\
\hline & m. $18-20$ & hear, & $\mathrm{E} b-\mathrm{D}-\mathrm{E} b-\mathrm{D}$ \\
\hline & m. 23 & -pals; & $\mathrm{B} b-\mathrm{A}-\mathrm{B} b$ \\
\hline & m. 34-36 & hearse. & $\mathrm{E} b-\mathrm{D}-\mathrm{E} b-\mathrm{D}$ \\
\hline \multirow[t]{4}{*}{ "woe" } & m. 10-11 & woe. & $D-C-B$ \\
\hline & m. $14-15$ & cry of fear, & $D-C-B$ \\
\hline & m. 26-27 & blood down palace walls. & $\mathrm{D}-\mathrm{D} b-\mathrm{C} b-\mathrm{B} b b-\mathrm{A} b$ \\
\hline & m. 30 & harlot's curse & $D-C \#-B$ \\
\hline
\end{tabular}

Example 3: Vaughan Williams, "London," Motive Chart 
Each motive is heard twice in each section and undergoes some level of variation that is directly tied to the text of the poem or to a specific musical function. Additionally, each motive group takes on a slightly different interpretive meaning between sections. For example, the first motive ("charter'd street") is the least varied, with slight alterations in length reflecting the text. In section A, the motive is heard in measure 2 on "charter'd street," and again on "ban, The mind-..." in measure 16-17. These two instances reflect the restrictive nature of both the mapped streets and the social "manacles" placed on society. In the second section, the motive shifts to embody the cries of the chimney-sweeper and the cursed infant (measures 21 and 32, respectively). This final sounding of the motive is especially haunting, where, acting as a vocal climax, the first note (F5) is elongated, both depicting the wail of the infant and signaling the resignation of the singer as he settles back into the melancholy, meandering melody of the last phrase.

There are two cadential figures in "London," the "flow" motive, which serves as the main cadential figure by appearing at the end of each section, and the "woe" motive, which acts as a secondary cadential moment between stanzas. Each of these motives has a pair of restatements that are not used as cadential material, and each motive undergoes some level of variation. The "flow" motive is varied mostly through length, and, apart from the musical function, serves both a descriptive and symbolic purpose. The first occurrence of the "flow" motive in measure 5-6 lasts for a total of $3 \frac{1 / 2}{2}$ beats and is directly related to the visual flowing of the Thames. When the motive reappears as a cadence in measures 18-20, it has been transposed down a fifth and elongated to 5 beats with a fermata on the last beat. This time the motive is symbolic in nature. The stagnation of the alternating half steps paired with the expansion of the motive evokes a sense of pause for the speaker to really 
listen and hear the "mind-forg'd manacles" of the people around him. The second section has similar instances of the "flow" motive. The motive appears in diminution in measure 23 on the second syllable of "appals," taking the fluent description of the Thames and turning it into a terse chastising of the "black'ning church." Similarly, the ending cadence in measures 34-35 echoes the stagnant symbolism of the cadence in section A, bringing the piece to a melancholic end on the word "hearse."

The "woe" motive undergoes the most variation and offers interesting points of interpretation throughout the piece. Symbolically, the first section occurrences are fairly straightforward: the motive is heard on "woe" in measures 10-11 and again on "cry of fear" in measures 14-15, obviously providing a descriptive connection between "woe" and "cry." The "woe" motive in the second section is equally as descriptive, painting the vivid images of "blood down palace walls" and the "harlot's curse" (measures 26 and 30, respectively). However, in the second section, Vaughan Williams varies the motive, alternately lowering and raising the second and third notes ( $\mathrm{C}$ and $\mathrm{B})$. This adds to the already complex musical function of the "woe" motive apparent in the first section. The contour and structure of the figure is directly related to the "charter'd street" motive (a descending whole- then halfstep), which brings into question the "special musical occurrence" discussed above. The first appearance of the "woe" motive in measure 10-11 serves as a cadence to the first stanza of text, and introduces two variable scale degrees, C and B natural. One can argue that, because of the musical relation between the two motives, the "charter'd street" motive is foreshadowing the cadential "woe" motive, making the E $b$ a special musical event and pointing the piece to D Aeolian instead of Phrygian. This idea is supported further by the fact that the "woe" motive itself employs non-scalar tones within the octatonic passage 
(since the $\mathrm{C}$ and $\mathrm{B}$ naturals cannot both occur in the particular octatonic scale used in the piece). Therefore, it would appear that Vaughan Williams is highlighting the A section with motives that employ special cadential elements, effectively blurring both the modal and octatonic passages.

The D Aeolian argument becomes harder to prove with the opening phrase of $\mathrm{A}^{\prime}$, as mentioned earlier. Here, the "charter'd street" motive is clearly in D Phrygian because of the opening phrase, suggesting that perhaps the $\mathrm{E} b$ is not as "special" as first thought. The transition to octatonic is the same as in section A, but both instances of the "woe" motive are altered. The "woe" cadential figure in measure 26 that marks the end of stanza 3 contains an added note and lowered scale degrees, $\mathrm{D}-\mathrm{D} b-\mathrm{C} b-\mathrm{B} b$. The aural effect is quite vivid: the chromatic descent grotesquely illuminates the slow oozing of blood down the palace walls and the added eighth notes slightly slow the singer down, drawing the listener into the gory scene. Musically, the change in notes means only the $\mathrm{B} \not b$ (enharmonically, A) is out of place within the octatonic scale, and the added eighth notes cause the descent to go one step further, ending on an $\mathrm{A} b$ instead of $\mathrm{B}$ घ (again a note within the octatonic scale), and almost rectifying the variable scale degrees of the previous occurrence in the A section. The second appearance of the "woe" motive in A' similarly remains in the octatonic mode. The "harlot's curse" (measure 30) contains a raised C\# before descending to the original $\mathrm{B} \sharp$. This instance, while relating intervallically to the previous occurrence, is more symbolic in nature. Here, the motive is more rigid, remaining in the octatonic realm, just as the "youthful harlot" is stuck in her own social position. The changes Vaughan Williams writes between the A and A' sections suggest that perhaps the modality of the piece is not meant to be set in stone, that the piece is meant to have a little 
of each proposed analysis. The first section, with its blurry modal directions, echoes the aimless wandering and melancholic attitude of the speaker, while the more direct $A^{\prime}$ section equally reflects the speaker's impassioned disgust for the described public scenes.

The instances of variation within "London" encourage a myriad of both analytical and interpretive choices, all with intellectual merit. Vaughan Williams's "London" is an intimate and nuanced interpretation of Blake's poetry. The motivic unity, modal tonality, and a cappella melody recall the storytelling of folk song. It is as if one is being let in on a personal moment of expression or sitting by the fire listening to the tale of a weary traveler who has seen the hardships and heartache of humanity.

\section{BRITTEN}

"London" is the first of the Songs of Experience that Britten sets in his Songs and Proverbs. The setting is introduced by the first Proverb, which highlights the irony of society's condemnation of certain human traits:

The pride of the peacock is the glory of God.

The lust of the goat is the bounty of God.

The wrath of the lion is the wisdom of God.

The nakedness of woman is the work of God.

In short, the characteristics most shunned by religion (pride, lust, wrath, nakedness) are, for Blake, not only created by God, but are aspects of God himself. The lines poignantly tie to the oppressive nature of Blake's "London" and create a stark contrast both musically and textually to the bleak, unsettled environment of the poem. The proverb is introduced by an opening flourish in the piano spanning five octaves. The lines of text are pronounced on single pitches, giving them an air of assertiveness, which is aided by the unwavering quarter-note octaves in the accompaniment underneath. The final line of text is set a tritone below the preceding phrase and the diminuendo creates a sense of hushed "awe 
and foreboding." 175 The transitions from proverb to song are kept simple. Here, after the voice sounds its final note $(\mathrm{F} \# 3)$ the piano continues octave quarter-notes until the last whole note interval changes to a $7^{\text {th }}$ creating a tone cluster with the voice for just a moment (F\#3 - G2 - A1). This steady, dissonant trichord serves as the transition into "London." There is a musical connection, as well as textual, between the Proverb and song. The four melodic pitches in Proverb 1 (B b , D, C, F\#) are repeated in the opening four notes of the melodic line in "London," which eventually includes all twelve chromatic pitches. This subtle relationship, though difficult to distinguish upon initial hearings, is a prime example of the rich interconnectivity of the overall cycle.

In Britten's "London," the word "wander" becomes the unifying idea that is carried through the entire song. The song begins with a four-measure piano introduction marked 23 , indicating that there could be either two or three half-notes per measure. The rhythmic pattern is quintuplet eighths in the right hand set against quarter-note triplets in the left. The uneven rhythm and inconsistent meter creates the effect of an aimless "wander" as well as underlying tension and unease.

The tonality of the introduction also contributes to the ambiguous atmosphere. The key signature suggests either G minor or B b major, but neither piano line is firmly in either of those keys. The right hand is a combination of two segments combining whole-tone and diatonic figures. The first quintuplet makes up a whole-tone scale beginning on $\mathrm{F} \#(\mathrm{~F} \#-\mathrm{A} b-\mathrm{B} b-\mathrm{C}-\mathrm{D})$. The second quintuplet is the first five notes of $\mathrm{B} b$ major $(\mathrm{E} b-\mathrm{F}$ - D - C - B b ). The left hand similarly has a combination of diatonic and whole-tone elements. The first triplet arpeggio seemingly points to $G$ minor $(G-C-D)$, but the $A b$ in

175 Meister, “Interaction," 73. 
the second triplet points to possibly a different grouping, where the $\mathrm{G}$ acts as a pedal point below the movement of $\mathrm{C}-\mathrm{D}-\mathrm{A} b-\mathrm{D}-\mathrm{C}$ (relating to the whole-tone movement in the right hand). With the introduction of $\mathrm{F} \#, \mathrm{E} b$, and $\mathrm{B} b$ in measure 3 , the left-hand completes its whole-tone figure, echoing the pitch content of the right hand. The ambiguous nature of the combination of elements exists in the overlapping of opposite sonorities: when the right hand is playing a whole-tone quintuplet, the left hand is sounding a diatonic arpeggio and vice versa (when the right hand has the 5-note $\mathrm{B} b$ major figure, the left-hand is wholetone-esque). A C major chord in measure 4 suddenly breaks the overall sense of confusion created by the overlapping piano parts. The chord is approached in the right hand by the descending line of $\mathrm{D}-\mathrm{C}-\mathrm{B} b-\mathrm{A} b$, which then breaks the whole-tone movement in favor of a half-step descent to $\mathrm{G}$ with the $\mathrm{C}$ a fourth above. Similarly, the left hand breaks its pentatonic descent of $\mathrm{A} b-\mathrm{F} \#-\mathrm{E} b-\mathrm{D} b$ and rises a minor third to $\mathrm{E}$ natural, a pitch that has not yet been heard in the song. The fermata on the whole-note major chord adds a layer of sudden stillness in contrast to the rambling movement of the previous measures, bringing the introduction to a somewhat-out-of-place, almost unsettling, tonal end.
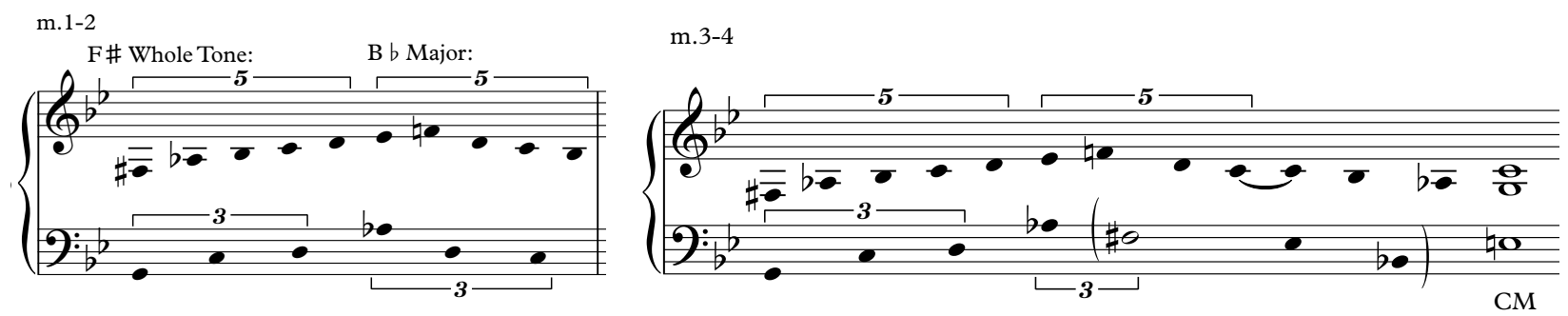

Example 4: Britten, “London,” measures 1-4 Reduction

The end of the introduction also begins a pattern of breath marks that are used to differentiate vocal phrases for the first half of the piece. The breath marks are interesting: they only appear in the first half of the piece (which includes the first two quatrains), and 
the breath mark positions are not all the same (e.g. they do not all correspond with exact line differentiations). The first three breath marks are placed every four bars, at the end of the introduction (measure 4), and at the end of each of the first two lines of text (measures 8 and 12, respectively). The next breath mark comes after two lines of poetic text, signaling the end of the first stanza. Subsequently, this breath mark also signifies the point in the music where the ending tonality of each phrase changes. Here, in measure 20 , the ending held chord shifts to D Major (from C Major). The next two breath marks return to defining a single line of poetic text, but also include tonal shifts (to E b Major in measure 24 and F\# Major in measure 27). Now, the harmonic shifts come more quickly, pairing with the commas that separate the lines of text into two segments: B b Major in measure 29 and E b minor in measure 31 . The final breath mark symbolically closes the first main section of the piece and marks the end of the second stanza with a G Major chord in measure 35 . While the breath marks act as delineation between phrases, they also take on an interpretive role very much akin to Blake's deceptively simple poetic structure. Each mark steers the singer to a particular reading of the poetry, directing him to take pause after each idea that Britten deems important and creating a map suggestive of the "charter'd streets" of the city.

The introduction is repeated as accompaniment for the first line of text, while the melodic line seems to blend aspects of the accompaniment as well as serve as a reminiscence (as mentioned above) of the Proverb statements. Here, the voice begins on F\# and makes a large leap of a minor sixth to $D$, echoing the span of the first quintuplet in the right hand of the piano. The melody then continues down a whole-tone scale, which is an augmented retrograde of the same quintuplet figure. The longer rhythms of the vocal line soar above the agitation of the piano below, until both instruments come together in 
consonance on C major. Britten's use of a C major tonality (arguably one of the most tonal and consonant sounds in traditional harmony) in this abrupt and unprepared manner reverses its inherent effect to one of startling unease and adds to, rather than releasing, the tension in the piece.

The second vocal phrase contains many of the same musical elements as the first, with slight alterations and a longer hold on the $\mathrm{C}$ major chord in the piano while the voice depicts the slow "flow" of the Thames. Lines three and four of the poem are grouped together with shapes and contours similar to those of the previous phrases, but this time Britten transposes the piano and moves from a predominantly whole-tone tonality to Lydian modality. Both the right and left hand retain the same rhythmic figures. The right hand quintuplets now spell an A b Lydian scale $(A-B-B-C-D-E b-F-G)$ and the left hand figures center around a C - D dyad bookended on either side by an F\# and B b , creating a dissonance with the $\mathrm{F} \boxminus$ in the right hand. The Lydian mode is echoed in the voice, which, apart from the all-important half-step between E $b$ and D, moves in mostly whole-tones, relating to the previous phrases. Instead of keeping the same modality throughout the two grouped phrases, Britten shifts again in measure 16, transposing the right hand up a tritone, and using a D Locrian scale (D - E b $\mathrm{F}-\mathrm{G}-\mathrm{A} b-\mathrm{B} b-\mathrm{C}$ ), while the left hand moves up a minor $2^{\text {nd }}$ (this time creating a dissonance between $\mathrm{E} \sharp$ and $\mathrm{E} b$ ). Like the previous phrases, the lines are pulled together once again in an abrupt and unsettling consonance in D Major, with the F\# and A of the chord evolving out of a descending left hand line. 

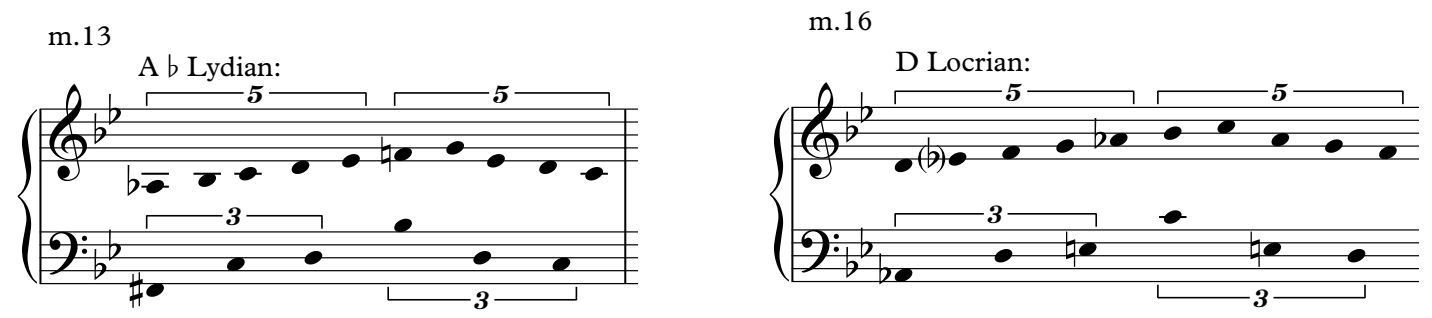

Example 5: Britten, "London," measures 13 \& 16 Piano Reduction

The second stanza continues in the same fashion as the first, keeping the same rhythmic structures as before and shifting between modality and tonality. The right hand and voice move through B Mixolydian (m. 21) with a cadence in E b Major, C minor (m. 25) with a cadence in F\# Major, D b Major (m. 28) with a cadence in B b Major, F Mixolydian (m. 30) with a cadence in $\mathrm{E} b$ minor, and finally ending with a $\mathrm{G}$ whole-tone scale (m. 32) reminiscent of the beginning of the piece with a cadence in G Major. The left hand undergoes similar transpositions, always keeping a dissonance present between at least one of the right hand pitches.

Along with the constant shifting of modality and tonality, there are noticeable text details within the second stanza. First, one can notice the deliberate elision of the word "ev'ry" throughout the second stanza. This is in direct contrast to the particular attention Vaughan Williams placed on the non-elided version of the word in the original poetry. Britten focuses our attention to the overall phrase, instead of the singular word, and highlights the nouns of each phrase with the ending held chords and fermatas (e.g. "Man," "voice," "ban," etc.). There is also descriptive writing at the end of line six (measures 25-27) where the piano introduces an F\# minor chord and the voice depicts the Infant's "cry of fear" with an elongated phrase of chromatic neighbor tones (enharmonic F\# - F and C - C \#) before giving into the minor resolution. 
From measure 36 on, Britten does away with the breath marks and the song remains continuous through the attacca into the next Proverb. There is also a change in mood here, at the beginning of the third stanza. The direction of the piano writing reverses, descending where it previously ascended and vice versa. The tessitura is higher, both hands written in treble clef, and the accompaniment overall less dissonant. The atmosphere moves to one of tenderness and "woe," with the Chimney-sweeper's cries depicted through an oscillating melody and sigh-like melismatic figures in the vocal line. The mention of the two societal institutions, the church and government (lines 10 and 12, respectively), brings a halt to the accompaniment movement and the sounding of three whole-note major chords for each line. The contrast between the undulating piano movements and the stark bell-like chords serves as both a method for highlighting the text and perhaps a comment on the implacability of societal oppressors ("Church" and "Palace") versus the sorrowful and uncertain existence of society's victims ("Chimney-sweeper" and "hapless Soldier").

The original piano agitation returns with the start of the final stanza. Britten takes the only liberty with Blake's text in the song with a repetition of the line "the newborn Infant's tear." The repetition offers the voice an opportunity to rise to an expressive and vocal climax in preparation for the "deliberately understated" last line, "And blights with plagues the Marriage hearse." ${ }^{176}$ Britten again chooses stark, seemingly contradictory major chords to accompany the final bitter sentiment. The three major chords, E major - C major - A major, in the piano support a broken A $b$ augmented triad in the voice, offering no sense of final rest or union between the two. The descent of the last vocal phrase carries

176 Meister, "Interaction," 86. 
into the piano postlude, which is a repeat of the introduction but an octave lower, becoming softer and softer until it simply disintegrates into the next Proverb.

Britten's “London" is a vivid depiction of Blake's bleak, dark, and oppressive view of his home city. The blending of tonality and modality, paired with the overlapping of rhythmic figures and metric ambiguity emphasize the restless, agitated, and often hopeless existence of the subjects in the poetry. Like Vaughan Williams, Britten focuses on the bitter indignation of the speaker, with both pieces evoking a sense of personal reflection and melancholy while meandering the streets. While Vaughan Williams relies heavily on the alteration of musical motives for symbolic relevance, Britten keeps things building in anticipation with occasional stops in the movement for poetic purposes. Both composers employ modality in their interpretations of "London." Vaughan Williams's use of Phrygian and octatonic scales evoke an organic folk-like telling of the poetry, his use of specific variable pitches meant to communicate and interpret the nuanced text. Britten's modality is used to create an atmosphere of agitation and unease, constantly shifting and transposing, never allowing the singer to settle into any one pitch area. Both composers use melismatic writing sparingly, reserving such events for important moments in the poetry. Neither composer directly evokes the visual image that accompanies the poetry, both instead focusing on interpreting the aimless, despondent nature of the text. 


\section{“A Poison Tree”}

1 I was angry with my friend:

I told my wrath, my wrath did end.

I was angry with my foe:

I told it not, my wrath did grow.

5 And I water'd it in fears,

Night \& morning with my tears;

And I sunned it with smiles,

And with soft deceitful wiles.

9 And it grew both day and night,

Till it bore an apple bright;

And my foe beheld it shine,

And he knew that it was mine.

13 And into my garden stole

When the night had veil'd the pole:

In the morning glad I see

My foe outstretch'd beneath the tree.

"A Poison Tree" is a tale of hidden feelings and the result of repressed, secret desires. We have discussed Songs that comment on society's wrongful view of instinctual thoughts, mostly pertaining to sexuality (as in "The Sick Rose" and the final stanza of "London"). But "A Poison Tree" depicts an actual consequence of not voicing one's inner feelings. The matter-of-fact language does not evoke the same visceral or emotional reaction as the descriptions in "London," but clouds the moral compass of the speaker and makes for ambiguous interpretations. The lines are all written in past tense except the final couplet, signaling the narrative as a retrospective and calling into question the purpose of the speaker's words. Is the poem a retelling of the speaker's conscious choices or an attempt to piece together the unconscious actions that led to the foe's outcome? Did the narrator intentionally hide his anger to force the demise of his foe or was this a result of externally imposed self-restraint, perhaps by society or the church? He is "glad" that his foe 
is dead; is that necessarily bad? His foe did steal from his garden, but was the narrator tempting the foe on purpose, knowingly luring him to his death? Telling his feelings to his friend solved their dispute, would the same be true if the speaker voiced his thoughts to his foe? Is this a cautionary tale to always speak your mind, or a commentary on the inevitable result of a society that favors same-ness and order over communication and instinct?

"A Poison Tree" exhibits many of the poetic attributes common to all the Songs: parallel constructions, tight rhymes, alliteration, vivid imagery, and the use of simple language and syntax that expertly portrays a complex network of symbols. ${ }^{177}$ Amidst these characteristics, Blake is able to layer multiple possible interpretations into the short four quatrains. Two have already been revealed: either the speaker knowingly deceives his foe into death, or the foe meets his demise by his own fault (theft) unbeknownst or unconsciously of the speaker (who is then pleasantly surprised by the outcome). There is, however, a third layer of meaning. An earlier version of "A Poison Tree" can be found in Blake's Notebook under the title, "Christian Forebearance," an ironic word-play on the religious idea of restraint and tolerance. ${ }^{178} \mathrm{~A}$ natural correspondence exists, then, between the poisonous tree bearing an apple and the forbidden tree of Eden. The speaker's apple, the symbol of man's fall from grace and ejection from Eden, was born out of anger and hatred toward a single person. The apple was deceivingly "bright," "shiny," and beautiful, enticing the foe to take a bite and ultimately succumb to its poison. This narrative implies that the Genesis story "promotes and expresses a deeply confused moral vision." 179 Was the apple in Eden put there specifically for man to fall, its creator knowing that man could not

177 Meister, "Interaction," 104.

178 Gillham, Contrary States, 177.

${ }^{179}$ Lincoln, commentary, 197. 
resist? These questions of what is good and what is evil — right versus wrong, honesty versus hypocrisy, expression versus repression, clarity versus obscurity — are left unanswered in the poem and up to the personal interpretation of the reader.

Unlike "London," whose accompanying image adds symbolic meaning to the poetry, the image for "A Poison Tree" is a direct depiction of the final scene of the poem. The tree occupies most of the plate with its wide trunk and leafless branches growing from the bottom right corner. The largest bough reaches to the left with slanting twigs and branches hanging over a "death-grey" naked body. ${ }^{180}$ The outstretched arms of the corpse elicit the image of the crucifixion. The tree extends up the right side of the plate and envelops the title and main body of text with spindly barren branches. The color of the plate is of particular importance, being one of the "coldest" plates in the Songs. ${ }^{181}$ Apart from the redbrown lettering and the touches of gold that signify the sunrise, all other tones are cool: the blue of the receding night sky, the dark gray of the tree, the lifeless gray of the body, and the cold green of the grass. The border around the main image keeps with the poisonous atmosphere of the garden with sharp barb-like brushes on either side in cool tones. For all the ambiguity of the poetry, Blake's visual image is hauntingly vivid and clear.

\section{VAUGHAN WILLIAMS}

Vaughan Williams's setting of "A Poison Tree" uses a variety of compositional techniques to express the conflicting and ambiguous nature of the poetry. It is one of the most contrapuntally active songs in the cycle and the weaving of the two instruments parallels both the visual image of the winding tree and the conflicting moral attitudes of the text. Like "London," "A Poison Tree" is in modified binary form (AA') with the four

\footnotetext{
180 Ibid.
}

181 Ibid. 
quatrains of the poem evenly divided into $2+2$. Ambiguity is present right at the onset of the piece with three deceptive elements occurring in the first two measures. The key signature points to either F major or D minor and the time signature is $\underset{4}{4}$. The oboe line in measures 1-2 seemingly points to D Dorian, but the $\mathrm{C} \#$ in measure 3 turns the modal scale into: D - E - F - G - A - B - C\# - D, Dorian-esque with a raised seventh scale degree. The meter is also skewed in the second half of measure 2 with the syncopation into the quarter note triplets, which give an overall feeling of two beats per measure instead of four. Melodically, there is an abundance of minor thirds and tritones throughout the piece, both in the voice and oboe. The tritone, of course, has been symbolized as a devilish, evil interval, but it also serves as a symmetrical division of an octave (spanning six semitones). A minor third is also tied with somber moods, especially when sounded between the tonic and the third of the scale, as it is most often in "A Poison Tree." However, like the tritone, a minor third symmetrically divides the six semi-tones of a tritone. While it appears that Vaughan Williams is employing these intervals more as aesthetic or aural symbols, it is interesting to note that while most musical elements in this piece are meant to conflict or oppose, the relationship between the two "motive-like" intervals is symmetrical and organic: one builds another, perhaps like the growing of the speaker's "wrath."

The voice begins in a "question-and-answer" relationship with the oboe, entering with a solo phrase that spans a minor third. The oboe's answer grows out of the vocal phrase by echoing the voice's final minor third ascent from F - D and continuing its ascent up a tritone to $\mathrm{A} b$, the lowered fifth scale degree. The voice echoes the $\mathrm{A} b$ and adds a lowered second scale degree $(\mathrm{E} b)$ in measure 8, ending the phrase in Locrian on the D final, symbolizing the succinct journey of "wrath" for a friend. The lowering of the $E$ in the 
final segment of the above phrase is reminiscent of the cadential figures in Vaughan Williams's "London." The "woe" figure in "London" contains the variable scale degrees of C and B (much like the E discussed here) and the cadential "flow" motive is also connected to this ending figure, highlighting the final half-step of $\mathrm{E} b-\mathrm{D}$.

The oboe returns to the Dorian mode with a repeat of its first musical phrase to usher in the voice for line 2 of the poem. This time, the voice is the first to span a tritone, which now forms a portion of a D octatonic scale: D - E - F - G - A b (measures 10-11). This phrase is followed by a sequence of ascending minor thirds ushering in the idea of the "wrath" beginning to grow. The minor thirds sequence can be seen as a transposition and expansion of the original D - F interval consistently heard since the onset of the piece. The first of the three intervals begins on $\mathrm{A} b$, again highlighting the tritone, and eventually completes the D octatonic scale with the addition of $\mathrm{B} b, \mathrm{C} b$, and $\mathrm{D} b$ (measures 12-13). The oboe foreshadows this growth with a D pedal beginning in measure 11 and continuing up a half step to $\mathrm{E} b$ (set a minor third above the voice's $\mathrm{C}$ ) before descending a tritone to the next pedal, A. The harmony on the downbeat of measure 14 in the oboe changes to an $\mathrm{A}$ diminished $7^{\text {th }}$ sonority, foreshadowing the upcoming shift in measure 15 to A octatonic in the voice and signaling the end of the first stanza.

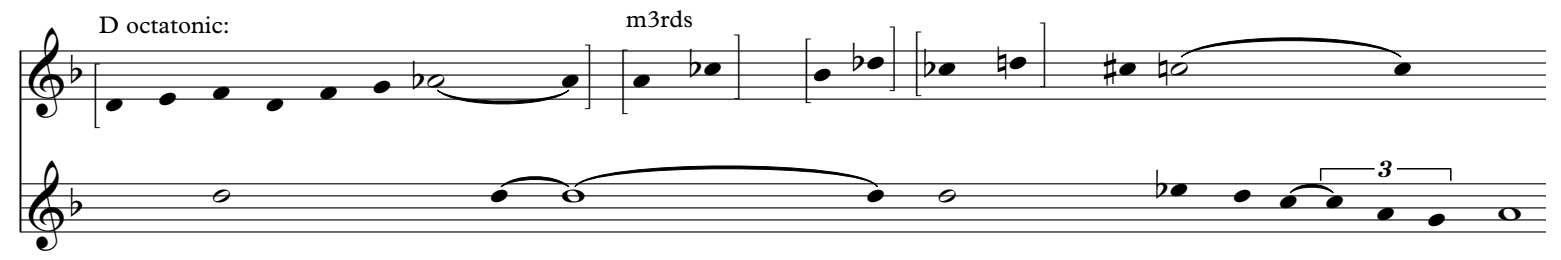

Example 6: Vaughan Williams, “A Poison Tree," measures 10-14 Reduction

These measures have another interesting element that compels discussion. Generally, dynamic markings in the Ten Blake Songs are minimal, usually with only a 
beginning mark with the rest left to the interpretation of the performers. "A Poison Tree" has three places where dynamic markings are present. The first two are at the beginning (a $p$ marked at the introduction) and the end (a decrescendo in the oboe line in the penultimate measure) of the piece, while the third is a series of two crescendos and a decrescendo in measures 13 and 14 shown above. The number of markings paired with the direct opposition of the crescendo in the voice over the decrescendo of the oboe makes this an important and poignant moment in the piece. Not only are the markings aurally interesting, they can be seen as symbols of ambiguity related to the text. It is as if the voice is excited that his wrath is growing, while the oboe knowingly backs away in moral judgment and continues on his own path at the start of the second stanza.

Here, in measure 15, the "question-and-answer" structure ends and both instruments retain obbligato lines in counterpoint as the "wrath" tree grows until the final phrase of the poem. The tonality shifts to octatonic passages with conflicting tonics (the voice in $\mathrm{A}$ and the oboe in F). The minor third interval is changed to major for the last two lines of the second stanza (measures 18-20), depicting the deceptive behavior of the speaker. The return of the oboe's introductory passage, signifying a new section and return of the Dorian mode, is now an octave higher and symbolizes both the growing intensity of the poetry and the maturity of the tree itself. The oboe continues in a high tessitura through the third stanza, but returns to its original octave for the final quatrain. Chromaticism increases through the A' section, most notably in the passage from measures 29 through 31. Here, Vaughan Williams layers a number of musical elements to both depict and interpret the climatic moment of death in the text. First, the oboe introduces the last stanza with an unusual descending eighth-note triplet figure (the only one in the piece), as if it was 
snaking down into the garden, perhaps a musical nod to the snake in the Biblical story of Adam and Eve's fall from Eden. The oboe continues its illustration of the thief through measure 30 by sneaking its way amidst the vocal line with tied quarter notes and syncopated rhythms that obscure the beat. Above the oboe, the voice has its longest chromatic passage encircling a tritone from A - E $b$. The symmetrical aspect of the partner octatonic sequences seen in section A (measures 15-18) has here dissolved into intense chromaticism in the vocal line where each ascending moment is different, first rising a minor $3^{\text {rd }}$, then major $3^{\text {rd }}$, then diminished $3^{\text {rd }}$, and finally returning to a minor $3^{\text {rd }}$. The chromaticism of the vocal line paired with the syncopation of the oboe suggests unease within the building cacophony, as if something just is not right - the foe should not be in the speaker's garden, the tree should not be tempting the foe, the speaker should not have grown the tree.

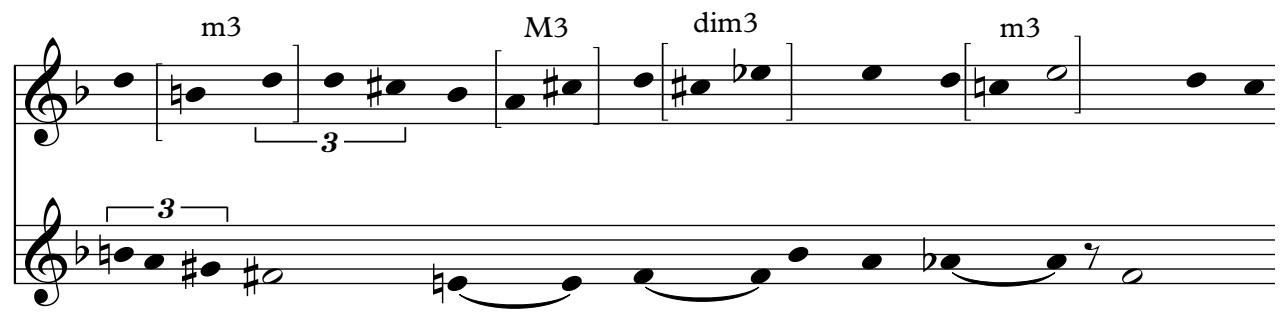

Example 7: Vaughan Williams, "A Poison Tree," measures 29-31 Reduction

This sense of "wrong-ness" ties over into the final two lines of the poem, where Vaughan Williams sets the line "In the morning glad I see" in a descending D Dorian phrase, contradicting the natural association of morning and gladness with the rising of the sun or ascending motives. The oboe echoes its section A counterpart with the minor $3^{\text {rd }}$ alteration to major and a change in harmony with added $\mathrm{F} \#$ and G\#'s until finally resting on a D5 in measure 33. The voice ends with a portion of a D octatonic scale (D - E b - F - G\# - A - B) recalling the phrase in measure 8 where he had ended his wrath with his friend, but here 
the finality of the wrath is tainted by death with the final ritardando and fermata prolonging the feeling of conclusiveness and both symbolizing the speaker's uncertain moral content with the outcome and depicting the visual image of the outstretched foe beneath the tree.

It is interesting to point out that "A Poison Tree" is the only piece in the cycle where the oboe line ends before the vocal line, bringing into light the significance of the D pedal and the function of the oboe itself in the song. It was suggested earlier that the oboe might represent an unspoken moral division in the text. In this interpretation, the pedal point at the end could signify the oboe's defeat; while it tried to steer the speaker in a different direction, the speaker won and his wrath ended through the death of his foe. Another interpretation is that the oboe is the speaker's wrath incarnate, with the D pedals signifying the beginning, middle, and end of the manifestation of wrath into a poisonous tree. In this interpretation, the first D pedal (beginning in measure 10) is the planting of the seed of wrath under the line "I was angry with my foe: / I told it not, my wrath did grow," with a crescendo leading into "grow." The second D pedal occurs in connection with the development of wrath into a fruit-bearing tree at the start of the third stanza (measure 23). And the final D pedal, then, is the conclusion of the speaker's wrath; the tree had done its job and can now die away, leaving the speaker released from wrath's hold. While the folk idioms embedded in "London" were meant to highlight the personal aspects of the text, the folk elements (modality, pedal points, rhythmic ambiguities) employed in "A Poison Tree" serve a symbolic purpose and encourage multiple interpretations and meanings, much like the original poem itself. 


\section{BRITTEN}

"A Poison Tree" and its accompanying proverb are the third group in the set. The ascending flourish in the piano that had accompanied the first two proverbs is now inverted in both motion and dynamics, creating a $p p$ downward sweep. The voice intones the short phrases, but there is a bit more vocal movement than in the "London" proverb with the voice rising a whole step in the first two phrases and falling a half step in the third. The text is three short phrases meant to introduce "A Poison Tree" by way of associating nature with man (perhaps a little ironically in the last line):

The bird a nest, the spider a web, man friendship.

The piano postlude echoes the downward sweep of the beginning, this time falling to the lowest note on the standard piano, A0. The beginning of “A Poison Tree" repeats the A octaves higher as the lowest note of a chord that begins the ominous introductory passage in the piano. The first four chords in the introduction sound all twelve pitches, but Britten's spelling of the clusters into tetra- and tri-chords, without any apparent clear ordering of the pitches, makes the section sound highly chromatic versus serial.

The key signature indicates either $\mathrm{G} b$ major or $\mathrm{E} b$ minor, and while the piano accompaniment offers little to suggest one way or the other, the first full vocal phrase begins and ends on $\mathrm{E} b$, making it the likely tonal center. Like the piano introduction, the first vocal phrase makes up a twelve-tone row, but is not fully serial. The repetition of the $\mathrm{E} b$ at the beginning and end of the phrase paired with two important musical motives and the parallel movement of the piano chords underneath generates an overall feeling of tonality. Britten chooses to highlight specific technical aspects of Blake's poetry with 
motives. The first example of this is his attention to the parallel phrases present in "A

Poison Tree." The two phrases, "I told my wrath," and "I told it not," (lines 2 and 4, respectively) introduce the first recurring musical motive in the piece (labeled the "wrath" motive). Barbara Meister relates the motive to the Fate theme in Beethoven's Fifth Symphony, but in place of the descending third at the end of Beethoven, Britten writes halfsteps, first ascending ("I told my wrath") then descending ("I told it not"). ${ }^{182}$ Meister warns about delving too deep into a connection between Britten and Beethoven in this piece, but does point out the importance with which Britten employs the motive and the drama that inevitably becomes connected to it within the piece:

In any case the way in which this rhythmic pattern is featured in the song does call attention to the drama inherent in it and in the text. The fact that the composer chooses to repeat portions of the text on this figure characterizes the entire composition, giving it a much stronger, more memorable outline than the two songs which precede it in the cycle...Whether or not Britten consciously desired it, the listeners' almost inevitable association of the rhythmic pattern with Beethoven's themes carries with it all the drama known to abound in the Fifth Symphony, a cargo perhaps not really too heavy for this portentous, lugubrious song. ${ }^{183}$

The next appearance of the "wrath" motive occurs at the first of many text repetitions employed in the piece (the second sounding of "I told it not") and is then taken up by the piano in polyphonic-like stretto to underscore the repetitions of "my wrath did grow" through measure 16. It is interesting to note that the entrances of the "wrath" motive in the piano stretto echo the voice's pitches on the first "my wrath did grow": D b , F, A b , $\mathrm{B} b$. The $\mathrm{E} b$ and $\mathrm{G} b$ as the first and last notes in the next vocal phrase (along with the $\mathrm{C}$ in the piano stretto) complete the $\mathrm{D} b$ scale.

182 Meister, “Interaction," 108.

183 Ibid., 109. 
A second recurring motive (the "growth" motive) is evident in the vocal line on "my wrath did grow." Not only does Britten take the liberty of repeating this heavily symbolic text throughout the song, he increases its descriptive meaning by writing it with an ascending triadic movement. We first heard the reverse of this motive in the final measure of the first vocal phrase, where the ending of the speaker's "wrath" when he told his "friend" is illustrated by a descending figure symbolizing closure. Once the "wrath" for his "foe" is introduced, however, there is no closure in sight and the "wrath" keeps ascending signifying its tension-filled growth. The piano ends the first stanza with a sounding of the "growth" motive in the left hand, while the right hand continues the heavy accented quarter notes of the "wrath" motive.

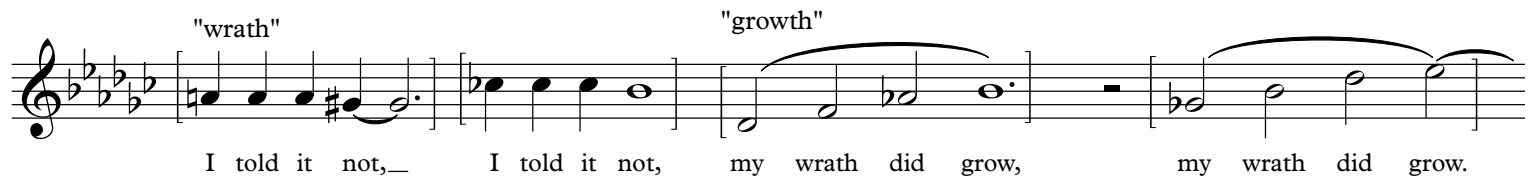

Example 8: Britten, "A Poison Tree," measures 10-16, Motive Reduction

Along with the presence of both musical motives and text repetitions, the next three stanzas are written in a pattern of decreasing musical activity with increasing dramatic tension. Stanza 2 begins in measure 17 with a fluid vocal line depicting the watering and nurturing of the speaker's wrath. Melismatic passages in the parallel phrases "And I water'd it in fears," and "And I sunned it with smiles," (lines 5 and 7) are echoed in the piano, signifying the wrath beginning to take an organic form and possibly suggesting the serpent present during the Fall. The "wrath" motive returns in both the vocal and piano lines for the repetition of "And with soft deceitful wiles," which is followed by the third repetition of "My wrath did grow" in a now descending "growth" motive. The quarter- and eighth-note rhythms of the second stanza are slowed down to quarter-note triplet figures 
in stanza 3, beginning in measure 31 . The voice returns to the steady pulse of the "wrath" motive after the tree had born its fruit, while the piano continues in the triplet figures, getting increasingly agitated under the foreboding somberness of the voice. The vocal line in the final stanza rhythmically slows down from quarter-note triplets back to the half notes and ties of the beginning, while the piano also returns to its sounding of the "wrath" motive in stretto. This time however, the piano foreshadows the coming conclusion with low accented octave bell tones continuing until the last vocal phrase. During the first two lines of the last stanza, Britten gives the piano all the major melodic and rhythmic figures from each previous stanza as a final build to the $f f$ climax in measure 47: the watery melismas of stanza 2, the plodding triplets of stanza 3, and the already mentioned "wrath" motive introduced in stanza 1.

All movement abruptly stops at the climax in measure 47 , with the piano sounding a 3-octave $\mathrm{E} b$, beginning a pedal point that continues into the postlude. The voice, for the last two lines of the poem, sings nothing but the two main motives of the piece. Beginning with an inversion of the "growth" motive, followed by two soundings of the "wrath" motive, and finally ending with another descending figure, this time rising and falling chromatically instead of triadically, symbolizing the end of wrath's growth. The piano repeats its blurry twelve-tone introduction as a postlude, but keeps the E b pedal and sounds one last "wrath" motive to complete the poem and usher in the next Proverb.

While the use and manipulation of musical motives is one of the most striking components in "A Poison Tree," there are other important elements that add to Britten's interpretation of the poem. For example, the second vocal phrase comprising the third and fourth lines of the poem is an approximate inversion of the twelve-tone row of the first 
phrase. This inversion adds a musical and analytical validation to the initial interpretive reason for changing the first descending triadic movement on "my wrath did end" to ascending on "my wrath did grow." The inversion is intact for the first two measures of the phrases, but varies in the final measures. The rising triad in the second four-note "growth" motive is major $(\mathrm{D} b-\mathrm{F}-\mathrm{A} b)$, rather than diminished $(\mathrm{C} b-\mathrm{A} b-\mathrm{F})$, though the final interval remains a whole step. The inexact-ness of the inversion may be another way Britten is thwarting true serialism in these passages, or it could possibly be an embodiment of the ambiguous moral nature of the poetry itself. The moral compass of "A Poison Tree" is not black-and-white and, therefore, does not translate to perfectly constructed inversions. Vocal phrase inversion:

m. 3-6

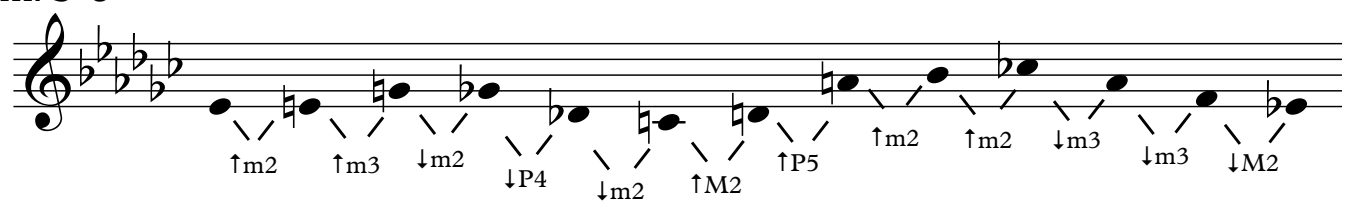

m. 9-14

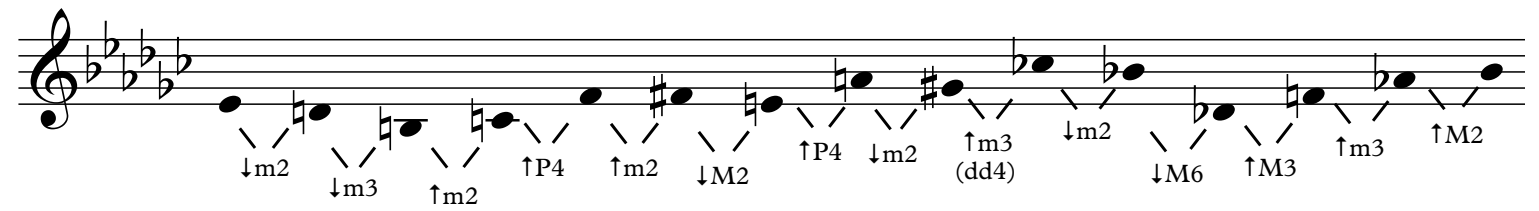

Example 9: Britten, “A Poison Tree," Vocal Phrase Inversion, measures 3-6 \& 9-14

Britten keeps the tension building in "A Poison Tree" through the layering of many different textural components. Each stanza both incorporates previous and introduces new musical elements with layers upon layers of textures, colors, rhythms, and motives until the release of the climax reveals the fundamentals of the piece. The polyphonic complexity and textural density of the music sets "A Poison Tree" apart from other settings in Britten's cycle. Graham Johnson describes the setting as "a cancerous fugue, part piling on part, until 
the page is teeming with malignant sextuples and tortured harmonies."184 Britten's writing simultaneously evokes the moral ambiguity of the text all while portraying the inescapable growth of the speaker's "cancerous" wrath.

Both Vaughan Williams and Britten choose to depict similar characteristics of Blake's “A Poison Tree." The underlying and constant growth of the speaker's wrath is evident in the obbligato oboe line in Vaughan Williams's setting and the recurring ascending musical motive in Britten's. The composers also highlight the difference between the first two parallel phrases, "my wrath did end" and "my wrath did grow," with closing, cadence-like figures versus open-ended phrases. The heavy, somber nature of the poetry is also similarly written into the music in both settings. The counterpoint between the oboe and voice paired with the modal and octatonic collections, often at odds with each other, gives a sense of seriousness and complexity that is different than the other pieces in the Vaughan Williams cycle. Britten's setting also employs counterpoint, among other textural and melodic devices, to evoke a sense of solemnity. Both pieces add weight and conclusiveness to the final lines of the poem, when the speaker's intended (or unintended) violence is fulfilled, suggesting that no matter the initial objective of the speaker in telling his retrospective, the ending is indisputably somber.

184 Graham Johnson, "Voice and Piano," in The Britten Companion, ed. Christopher Palmer (London: Faber and Faber, 1984), 301. 


\section{"The Fly"}

$1 \quad$ Little Fly,

Thy summer's play

My thoughtless hand

Has brush'd away.

5 Am not I

A fly like thee?

Or art not thou

A man like me?

9 For I dance,

And drink, \& sing,

Till some blind hand

Shall brush my wing.

13 If thought is life

And strength \& breath,

And the want

Of thought is death;

17 Then am I

A happy fly,

If I live

Or if I die.

"The Fly" is a somewhat perplexing anecdote about relationships in nature and the similarities and differences between humanity and the animal world. Upon first reading, the skipping rhythms, short crisp lines, and light language ("summer's play," "dance, / And drink, \& sing," etc.) may recall the state of Innocence rather than Experience. But, amidst the flippant attitude of the speaker, a darker more depressing view of life and purpose emerges. The speakers of Innocence (like in "The Chimney-Sweeper" or "A Little Black Boy") seem to have no fear of death because they see it as "the beginning of a new and more joyful existence" given to them by a "loving redeemer" who liberates them from the 
"trials of mortal life."185 The speaker in "The Fly" appears to take comfort in an opposite view, not necessarily fearing death, but not expecting a savior or redeemer either. Like the other Songs discussed, "The Fly" perpetuates multiple interpretations with most discrepancies embedded in the speaker's presumed stance on "thought" and how it affects one's life. A paraphrase of the poem may be as follows: the fly that the speaker has idly killed and the speaker are similar creatures. Each lives according to their nature until some unknown and unforeseeable force takes their life away. The question for interpretation is how the speaker views his nature and how the reader then views the speaker. There is an immediate flippancy in the language and rhythm of the speaker that suggests almost a selfdefeating attitude and either a conscious or unconscious irony in the speaker's use of the words "thoughtless" and "thought:" "if thought is life, then the 'thoughtless' speaker is already lifeless; if the want of thought is death, and one can be 'happy' in death, then happiness becomes equated with the want of thought."186 This convoluted view is echoed (somewhat) in an essay by John Grant devoted to "The Fly" in which he suggests that the poem is essentially a paradox, contrasting "the artlessness of the speaker and the awareness of the reader." 187 Grant agrees that, for the speaker, the presence of thought is life and its absence is death. He goes on to paraphrase an assumed train-of-thought for the speaker: “I'm not a particularly thoughtful fellow, but what I've done has made me think. What if being thoughtful is really living — and not being thoughtful is death (but so what?

185 Lincoln, commentary, 184.

186 Ibid., 184-5.

${ }^{187}$ John E. Grant, "Interpreting Blake's 'The Fly'," in Blake: A Collection of Critical Essays, ed. Northrop Frye (Englewood Cliffs, New Jersey: Prentice-Hall, 1966), 35. 
all men are mortal)?"188 This view of "so what?" echoes the happy-go-lucky mood of the poem, notably in the lines "For I dance / And drink \& sing" of the third stanza.

There is an alternate philosophical view of "The Fly" tied to the fourth stanza (beginning with "If thought is life..."). The speaker may be reciting these words in conscious irony (versus the unconscious and almost naïve tone alluded to above), equating his life with the fly's as Blake equates all living things and human experiences with the Divine. There is a definite slowing down of tempo in the fourth stanza, suggesting a pause for reflection by the speaker. The string of voiceless fricative consonants ("thought," "life," "strength \& breath," "death") forces the reader to take time and savor each of the meaningful words and their possible importance to the speaker. The pause is short-lived, however, and the quickness and levity of the text returns for the final stanza, as if the speaker is shaking off an internal confliction with his perceived attitude.

In the end, perhaps the speaker is not as "artless" as we first imagined. The entire poem could act as a metaphor for the sanctity and brevity of life and represent the speaker's (or perhaps Blake's?) questioning of what really happens when we die - do our thoughts live on or do we simply leave existence in a cycle of life and death? This cyclic idea is echoed in the visual image for "The Fly," where Blake depicts a scene of "summer's play" in the bottom half of the plate. Again, there is a recollection of the Innocence images, but the barren trees and "bare horizon" relates the seemingly happy activities to the "grimmer world" of Experience. ${ }^{189}$ There are three figures present in the image, a young mother, a small child, and an adolescent girl (none of whom are mentioned in the poem). The mother looks intently down to her child she is helping walk. While the pair seems content, their

188 Ibid., 41.

189 Lincoln, commentary, 185. 
expressions are more neutral than playful or happy. The young girl to the left stands apart from the others and, as John Grant notes, is about to strike a shuttlecock, playing a "game requiring two players by herself." 190 The apparent ages of the three figures suggest the cycle of nature: the child becomes the adolescent, who, in time, becomes a mother that will watch her own children, and so on. Again, this could be a depiction of the transient nature of life that is hidden in the ambiguous lines of the poem. The figures do not appear to be concerned with the thought of death and the mother is surely being "thoughtful" as she is intently tending to her child, unlike the "thoughtless" hand of the speaker who carelessly ends the life of the equally fragile fly. The colors of the plate are vibrant and warm, adding to the idyllic summer scene. All three figures are clothed in flowing robes of pastel colors and the greens and blues of nature are vivid and alive. The shading colors are almost entirely gold, both in the scene and text, and the border consists of bright green waves of vines on either side. The text of the poem is encompassed within a cloud, indicating perhaps the speaker's uncertainty in his life or perhaps shedding light on yet another possible interpretation that the speaker has in fact already perished and is gazing upon the world he left, commenting on his once-misguided view of life. "The Fly" is centered on the notion of "thought" and how it both ties us to and separates us from nature. Literally, there is no question about the flippancy of the language or the bouncing, frivolous rhythms, but symbolically, the reader is left to decipher the speaker's internal beliefs about life and his rightful purpose in it.

190 Grant, “Interpreting Blake’s 'The Fly'," 47. 


\section{BRITTEN}

"The Fly" is the fifth piece in Britten's cycle and is placed directly after "The Tyger."

The connecting proverb is just that: a connection of the texts. Three separate aphorisms are meant to bring the listener from the "wisdom" and sublimity of Blake's "Tyger" to the apparent "folly" embedded in the "The Fly."

The Tygers of wrath are wiser than the horses of instruction.

If the fool would persist in his folly he would become wise.

If others had not been foolish, we should be so.

The first and third statements are from the same Marriage plate (plate 9), while the second phrase is on plate 7. Each phrase treats the subjects of "wisdom" and "folly" differently. The first suggests that a primal and instinctual mind (the "Tygers of wrath") is, in fact, wiser than a domesticated learned mind. This idea is Blakean in the truest sense of the term. As discussed previously, Blake favors instinct and human nature above all else in terms of achieving a connection both to the natural and divine worlds. The second statement is less conventional and praises determination and persistence; if one is determined and passionate than even a foolish endeavor reveals some merit. Finally, the last phrase is an enigmatic homage to the past and how one can learn from the mistakes of those before them. The three phrases link "The Tyger" and "The Fly" both in context and literary devices. As mentioned above, there is juxtaposition between the sublime nature of the "Tyger" and the "thoughtless" speaker of "The Fly" that is highlighted in the interpretations of the proverbs. There is also a more literal connection with the mention of so many animals ("Tygers," "horses," and then the "Fly"), "a miniature bestiary," as Graham Johnson notes. ${ }^{191}$ Textually, not only is there an obvious repetition referencing the previous song in the

191 Johnson, Britten Voice and Piano, 216. 
opening phrase, "The Tygers of wrath," but also a foretelling of the next subject in the use of "f" alliteration in "fool," "folly," "foolish," and the beginning "fly." Musically, the proverb is an organic extension of the postlude for "The Tyger," leading attacca into the ascending piano flourish characteristic of most of the proverb settings and preserving the bass note as well as the next two notes of the Proverb's flourish. The vocal part, again, becomes more independent with the addition of 2-note melismatic figures on five words in the section ("wiser," "instruction," "folly," "foolish," and "be"). These little ornamentations are significant not only because they deviate so much from the syllabic writing of the previous proverbs, but they also foreshadow the rhythmic and textural nature of the coming song. There are three other musical aspects of Proverb 5 that are worth noting. The first is the use of the full chromatic scale in both the piano and the voice, but with different orderings. The voice sounds eight of the twelve pitches in the first phrase (D\#-E - D - C - B - D b$\mathrm{B} b-\mathrm{A}$ ) and completes the aggregate by adding an $\mathrm{E} b$ in line two and $\mathrm{G} b-\mathrm{A} b-\mathrm{G}$ in the last phrase. The piano is more symmetrical, sounding three groups of four pitches under each vocal phrase: $\mathrm{C}-\mathrm{D} b-\mathrm{B}-\mathrm{F} \# ; \mathrm{B} b-\mathrm{A}-\mathrm{F}-\mathrm{G} \# ; \mathrm{G}-\mathrm{E} b-\mathrm{D}-\mathrm{E}$. The second is the overall dynamic scope, ranging from the first crescendo to $f$ in the piano with the voice entering in kind, down to the final decrescendo to $p p p$ in the piano in the span of five measures. Lastly, for the first time in the cycle, Britten does not write an attacca into the next song, perhaps wanting to have a complete suspension of sound before the quick "fluttering" of the fly.

Britten's music for "The Fly" is a mixture of conventional insect and flying musical idioms and ingenious delicate alterations, creating a "drama in exquisite miniature." 192 The

192 Johnson, Britten, Voice and Piano, 217. 
piano begins with a flickering sixteenth-note figure that continues drone-like through the first stanza. Also, the accompaniment tessitura remains high (both hands in treble clef) for most of the piece. The key signature is F major (a key highly suggested by the final octave F's under the voice's B $b$ of the preceding proverb), though Britten rarely settles into this key, continuing the idea of the buzzing, flitting motion of an insect. The piano's alternating step figures sounded around the flitting sixteenth-notes are carried into the vocal line. After an initial repetition of "Little Fly," the voice sounds three instances of alternating halfsteps in rhythmic augmentation: B b - A, D - E b , C - B natural. Both the accompaniment and vocal lines change for the second stanza, which includes two questions: "Am not I / A fly like thee? / Or art not thou / A man like me?" Britten sets the two questions in an interestingly conventional question-answer form, with the first statement set to rising chordal figures and the second "answering" through a descending, perhaps affirming, line.

We saw an initial liberty with Blake's poem at the onset of the piece with the repetition of the opening line, "Little Fly." The third stanza extends the liberties by repeating words and phrases over a seven-measure section "whose rhythm and melodic curve seem designed to reflect the gaiety of Blake's words."193 The first statement of "For I dance / And drink, And drink and sing," repeating "And drink," is set to a chromatic ascending line suggesting perhaps cheerfulness, perhaps anxiety. The second utterance of "For I dance / And drink and sing" begins with a broken B minor chord (D - B घ - F\#) seemingly contradicting the happy notion of "dancing." There is also an interrupted sequence in the second half of this phrase, furthering the contradictory nature between

193 Meister, "Interaction," 132. 
music and text. The $\mathrm{D}-\mathrm{B}-\mathrm{F} \#$ figure is followed by the beginning of another broken chord a half-step down ( $\mathrm{C} \#-\mathrm{A} \#-$-), where the expected next note would be $\mathrm{E} \#$ completing an A\# minor chord. Britten, however, completes the phrase with an ascending diminished fourth to D, eschewing the expected sequence as if to remind the listener that this is not at all, in fact, a black-and-white "dance" figure. The final repetition of "dance / And drink and sing" is an overlapping near-repetition of the pitches of the previous phrase, highlighting the cyclical nature of the lines: $\begin{aligned} & D-B-F \#-D-C \#-A \#-()-D \\ & D-()-F \#-D-C \#-A \#-G-D\end{aligned}$. This final phrase is further emphasized with the first two-note melisma in the piece on the third repetition of "dance." The change from syllabic to melismatic writing is a consistent technique of emphasis for Britten in his Songs and Proverbs, and it continues here with another 2-note figure on the word "blind" in the last phrase of the stanza.

From this point on, Britten takes no other liberties with Blake's text, making the repetitions in this section all the more significant. The repeats themselves are asymmetrical and, read in succession, emphasize the jaunty almost inebriated musings of the speaker as if he is talking himself into a reckless dance of circles:

For I dance And drink, And drink and sing, For I dance And drink and sing, dance And drink and sing:

The emphasis Britten places on this stanza suggests his interpretation of the poetry leaning towards Grant's, in the essay mentioned earlier: that the speaker is wrapped up in a "so what?" attitude, enjoying his "thoughtless" life so much that he decides to just keep dancing and drinking and singing. Underneath these vocal phrases, the piano continues its fluttering "Fly" figure until a somewhat abrupt hold on a tied half-note in measure 28 introduces the fourth stanza. 
The start of the fourth stanza is markedly different with a measured chordal accompaniment dipping into the bass clef and a restrained vocal line, marked "heavier," consisting of quarter and half notes. A crescendo written into "breath" provides an opportunity for an effective "contrasting hush" on "death" at the end of the next vocal phrase. ${ }^{194}$ Though the mood of this short, seven-measure section offers a "thoughtful" side to the speaker and contrasts the previous seven measures in color and mood, the flitting of the fly (and perhaps the speaker's own want for levity versus gravity) is never far away, sounding in the piano between and after each vocal phrase. Britten labels the beginning of the final stanza "smooth," and writes a steady quarter-note line for the voice and piano reminiscent of the question-answer section in measures 12-16. Britten keeps the general motion of ascending question and descending answer, but the last phrase does not sound a definitive answer. The last vocal phrase consists of a whole-tone scale beginning on B $b$ in measure 35, surrounded by corresponding sonorities in the piano. The whole-tone movement is interrupted by the alternating half-step of C - B - C in measure 37 above an F major chord in the accompaniment. This half-step movement is repeated in the voice in measure 38, and is echoed in the piano with octave A b 's, creating an F minor chord. The voice ends on a falling whole step from $\mathrm{C}$ to $\mathrm{B} b$, which is harmonized over a $\mathrm{G}$ minor seventh chord (G-B b-F - G) by way of both half- and whole-step neighbor motion in the piano. Both the ever-present fluttering motive in between the notes of the chords and the continued undulation between the seventh chord and its F minor neighbor negates the inherent resolution of the G minor seventh, resulting in sonorities that sound transitional

194 Meister, "Interaction," 133. 
rather than final, ending with a last flutter of two B b 's before continuing into the next Proverb.

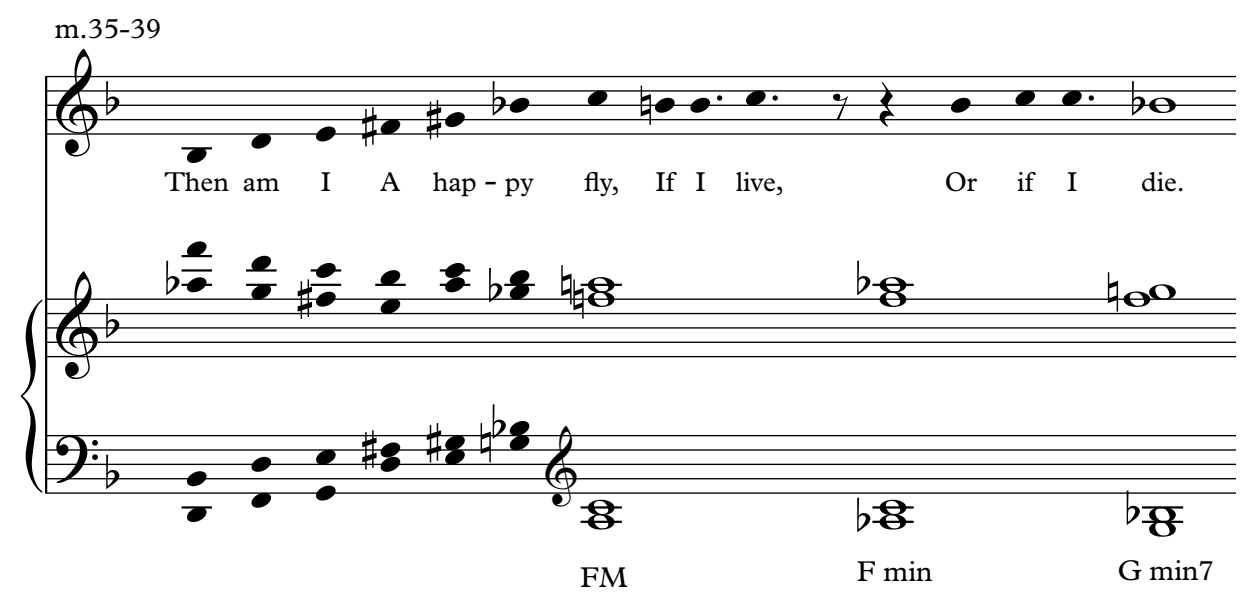

Example 10: Britten, “The Fly,” measures 35-39 Reduction

Britten's musical interpretation of "The Fly" highlights both the organic characteristics of the insect and the carefree, "thoughtless," nature of the speaker. The addition of the proverb as introduction, with two out of the three statements focused on "folly" and "foolish" behaviors, makes it difficult to imagine this setting conveying anything other than the flippant implications of the words or, as Lincoln comments, as a variant of "Pascal's wager:" "If death is not the end of thought, then I'll be happy; if it is the end of thought, happily I'll know nothing of it."195

\section{ROCHBERG}

George Rochberg, in his notes on Blake Songs: for Soprano and Chamber Ensemble, writes that "The Fly" "capsulizes the whole existence of man with incisive whimsical insight and satiric bite." 196 As the third song in the cycle, "The Fly," scored for flute, bass clarinet, and strings, is slightly different than the other three settings. There is an abundance of

195 Lincoln, commentary, 185.

196 George Rochberg, Notes by the Composer, quoted in Dixon, 43. 
sprechstimme that alternates with singing, which can be seen as not only a descriptive tool that recalls the tone-less buzzing of an insect, but also a comment on the unfocused and "whimsical" nature of the speaker. The tempo is faster, on the whole, than the other pieces in the cycle and both the dynamic and intervallic range is wider. Finally, there is no introduction or postlude, though the formal structure of the piece retains the ABA' form consistent throughout the cycle. The five stanzas are set in rounded ternary form with section A comprising stanzas 1 and 2, section B stanzas 3 and 4, and the final stanza making up the return of a truncated section A. There are short 2- and 3-measure interludes that divide sections A and B into segments, corresponding with the poetic stanzas, and a larger 5-measure interlude that signals the return of A and the final stanza. Like the other settings in the cycle, the accompaniment is composed of musical figures in small groups of two or three measures, while the vocal line employs both elements from the accompaniment and original, interpretive ideas.

On the surface, Rochberg's settings of Blake are markedly different than those of Vaughan Williams and Britten. His serial technique creates music that is heavily reliant on structure and form, which can be seen as a direct contrast to Vaughan Williams's melodycentric settings and Britten's tonal explorations. However, Rochberg's dedication to the text manifests itself through an expressive manipulation of serialism and unearths similarities in interpretation and approach between all three composers. It is the hope that, with the analysis of Rochberg's settings, his expressive intent is highlighted within the complex interconnectivity of the serial structures and a deeper appreciation of the communicative possibilities of serial compositions, most notably those with accompanying texts, is achieved. 
As mentioned earlier, Rochberg uses the same tone row for three of the pieces, which is introduced at the beginning of the first piece in the cycle, "Ah! Sunflower:"

$$
\text { A } \quad \text { B b } \quad E \text { E b E E }
$$$$
(9,10,3,4,0,1,2,5,6,7,8,11)^{197}
$$

The vocal line of "The Fly," presented in Example 11, has complete soundings of forms of the original, third, and sixth transpositions, as well as segments from other variations, inversions, and retrogrades of the row. The first two phrases of the vocal line (measures 16) make up the first full row, RI3, with the voice rising to an enharmonic repeat of the first note, now an octave higher ( $\mathrm{D}$ 5), to end the phrase. The second stanza also sounds a complete row, this time the retrograde R3 in measures 9-15. The B Section has instances of a complete row and smaller segments. After a complete sounding of P6 from measures 1622 comprising stanza 3, a progression of a tetrachord from sections of either R8 (order numbers 7-10) or I6 (order numbers 3-6), a pentachord made up of $7^{\text {th }}$ intervals not corresponding with any one row transformation, and finally a I0 hexachord completes the section. The pitch class content of this section comprises a nonachord, lacking pitch classes 1, 4, and 10; the first two of those are supplied with the opening of the final A section, suggesting a completion that unites the sections. The return of A echoes the initial RI3 row, this time without the repeated $\mathrm{D} b$ enharmonic, ending the vocal line on an $\mathrm{E} b$.

197 See Appendix F for the tone row matrix. 
Vocal Line Pitch Content Chart

\section{Stanza 1}

m. 1-6

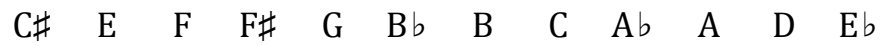
$\mathrm{RI} 3$

\section{Stanza 2}

m. 9-15

\begin{tabular}{llllllllllllll}
$\mathrm{F}$ & $\mathrm{D}$ & $\mathrm{C} \#$ & $\mathrm{C}$ & $\mathrm{B}$ & $\mathrm{A} b$ & $\mathrm{G}$ & $\mathrm{F} \#$ & $\mathrm{~B} b$ & $\mathrm{~A}$ & $\mathrm{E}$ & $\mathrm{E} b$ \\
& & & & & $\mathrm{R} 3$ & & & & & \\
\hline
\end{tabular}

\section{Stanza 3}

m. 16-22

\begin{tabular}{|lllllllllllll}
$\mathrm{F} \#$ & $\mathrm{G}$ & $\mathrm{C}$ & $\mathrm{C} \#$ & $\mathrm{~A}$ & $\mathrm{~B} b$ & $\mathrm{~B}$ & $\mathrm{D}$ & $\mathrm{E} b$ & $\mathrm{E}$ & $\mathrm{F}$ & $\mathrm{A} b$ \\
& & & & & $\mathrm{P} 6$ & & & & & & \\
\hline
\end{tabular}

\section{Stanza 4}

m. 26-32

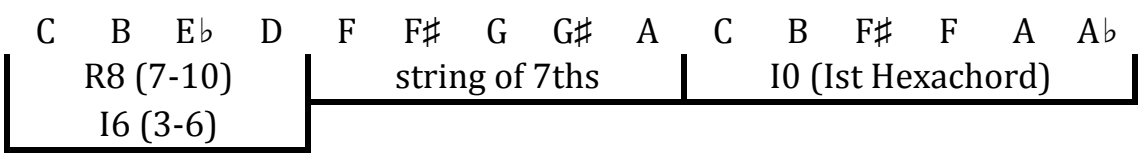

\section{Stanza 5}

m. 37-42

\begin{tabular}{lllllllllllll}
$\mathrm{C} \#$ & $\mathrm{E}$ & $\mathrm{F}$ & $\mathrm{F} \#$ & $\mathrm{G}$ & $\mathrm{B} b$ & $\mathrm{~B}$ & $\mathrm{C}$ & $\mathrm{A} b$ & $\mathrm{~A}$ & $\mathrm{D}$ & $\mathrm{E} b$ \\
& & & \multicolumn{1}{c}{$\mathrm{RI}_{3}$} & & & & & \\
\hline
\end{tabular}

Example 11: Rochberg, “The Fly,” Vocal Line Pitch Content Chart

The instrumental accompaniment uses cells derived from the row. Minor 3rds, major/minor 7ths, and major/minor 9ths are important building blocks in both the accompaniment and vocal lines. These intervals are then combined and expanded to create three- and four-note cells that often serve as recurring motivic figures throughout the piece. For example, the piece immediately begins with a sprechstimme vocal line, aurally depicting the buzzing of the fly and rising first a minor $3^{\text {rd }}$ from $\mathrm{C} \#$ to $\mathrm{E}$ and then a minor $9^{\text {th }}$ from E to F. The accompaniment similarly begins with parallel minor 3rds in the strings set a minor $7^{\text {th }}$ apart $(\mathrm{A}-\mathrm{F} \#$ in the violin and $\mathrm{B} b-\mathrm{G}$ in the viola). 
The accompaniment for the first vocal phrase also introduces three of the main instrumental motives to be heard throughout the setting: grace-note appoggiaturas, tremolos, and sixteenth-note arpeggio figures. After the strings entrance with two instances of cells based on minor $3^{\text {rds }}$ and major $7^{\text {ths }}$ (with an added grace-note in the violin), the strings begin a progression of tetrachords. The first tetrachord of stacked minor $7^{\text {ths }}(A-B b+E b-E)$, pizzicato, taken from the first tetrachord of the P9 row, is heard at the end of the first measure. After two other tetrachords based on $7^{\text {ths }}$, the strings are joined by the flute to end the section with a tremolo tetrachord in measure 3 - arguably drawn from order numbers 8-11 of either P10 or I5. The bass clarinet punctuates the opening vocal phrase with short 2- or 3-note figures based on $7^{\text {ths }}$ and $9^{\text {ths }}$ while the flute introduces the sixteenth-note arpeggiation figure, beginning on an off-beat and composed of an ascending minor $7^{\text {th }}$ and minor $3^{\text {rd }}$.

These "building block" intervals continue into the second phrase ("My thoughtless hand...") where the voice sings breathless sixteenth-notes punctuated by rests, with the disjunction emphasizing the "thoughtless" swatting of the fly by the speaker. The strings insert sixteenth-note figures into the vocal rests of the second phrase and, after allowing the voice to finish its action of "brushing away" the insect, returns with the woodwinds for a 2-measure intervallic connection into the second poetic stanza.

The vocal line of the second stanza (measures 9-15) is similar in content to the first, with large interval leaps of a $7^{\text {th }}$ or greater and alternating sprechstimme with sung notes. Here the voice sounds the second of the full rows in the movement, a retrograde of the prime form, R3, as mentioned above. Rochberg employs added repetition in the last tetrachord of the row, with repeated B b's, A's, and E's in measures 13-14. The two 
questions of the second stanza are each met with an initial rise in line followed by a large interval fall, perhaps suggesting that the speaker is either feigning inquisitive interest, or has pondered these questions before and has resigned to their inability to be answered clearly. The rhythm of the vocal line also suggests a cyclic pattern of question-and-answer with the line resembling a rough palindrome, beginning and ending with quarter-note triplets and following approximately the same pattern of quarter-, eighth-, and sixteenthnotes, with the center of the palindrome being the repeated B b 's in measure 13 . The woodwinds echo the vocal patterns at the beginning and end of the stanza. The flute alters the opening vocal figure of descending minor $3^{\text {rd }}$ and ascending major $7^{\text {th }}$ by rising a major $3^{\text {rd }}$ and then rising a major $9^{\text {th }}$ in measures $9-10$, comprising an inversion of the voice's set class 3-3 $([1,2,4]$ inverted to $[1,4,5])$. In measures $14-15$, the bass clarinet closes the phrase with a repeat of the same opening vocal figure displaced an octave (F-D - C\#). The rest of the accompaniment is filled out with figures and intervals common to the piece with trichords and tetrachords drawn from unordered segments of the row.

A big change in tempo and mood in measure 16 marks the beginning of section $B$, encompassing the third and fourth stanzas of the poem. Rochberg writes a forte fermata on G5 in the voice along with a $\quad \begin{aligned} & 3 \\ & 8\end{aligned}$ time signature and the word "Lusty!" written in bold type above the score. The $\begin{aligned} & 3 \\ & 8\end{aligned}$ appropriately introduces a waltz feel for the speaker's "dancing and singing," while the solo voice fermata and subsequent accompanimental silent downbeat serve as the perfect launching point for the carefree moment of the dance. The voice, again, sounds a full row, this time in original form (P6) and with extra note repetition liberties, from measures 16-22. The happiness of the "dance" is superficial, however, and is not successful in covering the underlying current of the certainty of life and death. The 
entire first half of the stanza is sung, but the slide off of the high B b on "sing," in measure 19, brings the vocal line back into sprechstimme, which now signifies the speaker's collapse from full, languid, happy tones to the bleak, imprecise utterings of the inevitability of death, "till some blind hand / shall brush my wing."

The accompaniment aids in the waltz-like atmosphere with rests or ties on the downbeat and emphasis on the second and third beats of the measures. Like the voice, the instruments are brought down from their forte "dance high," in measure 18, to piano held notes coinciding with the vocal line. In measures 22 and 23, Rochberg collapses the preceding flurry of movement back to the basic intervals that form the foundation of the cycle. The flute and bass clarinet form a string of descending $\mathrm{M} 7 \mathrm{~s} / \mathrm{m} 9 \mathrm{~s}$ below the voice, passing the figure to the strings who sound the same tetrachord of M7s (F\#-F, E b-D) heard in the woodwinds in measure 17, but now acting as a hauntingly $p p p$, straight-toned end to the stanza.

The death-like repose of this moment is brought back to life with the entrance of the bass clarinet in the 2-measure interlude between stanzas, measures 24-25. Rochberg sets up the subsequent philosophical stanza with a completion of an R9 row, with the starting pitch (B) heard as the last note of the bass clarinet's line in measure 23. The row is then separated into two segments: G\#-G-F\#-F-D; C\#-C-E - E b - B - A. These segments introduce the voice, who, for the first time, does not sound a full row, instead echoing the bass clarinet's segmentation with a four-note figure from either R8 or I6: C - B - E b-D, followed by a string of $7^{\text {th }}$ intervals making up the first two lines of the stanza. Rochberg highlights the summation of the poem ("And the want / Of thought is death;") by introducing a quintuplet pattern in the voice (the first heard in the cycle) and adding a bit 
of text painting before the word, "is." The short rest before "is" in measure 30 symbolizes a hesitation before saying the final words, "is death," as if saying the words actually makes them true and brings seriousness to the poetry that the speaker has previously been reluctant to do. This contradicts with the original phrasing of the poem, where the break in the lines comes after "want," instead of before "is," almost forcing the reader to not pause and contemplate the thought of death. In terms of pitch, the voice sounds an I0 hexachord, which both separates it from the previous phrase and connects it to the other stanzas where full rows are present. The accompaniment is kept sparse for the final vocal phrase, with a pentachord in the strings marked fff, which, when combined with the voice's A5, forms the first hexachord of P6 and is interjected right before the breathless rest in measure 30. This is followed by a quick figure in the violin, drawn from I6 and I7, which ties into the 5-measure interlude that introduces the final stanza (measures 32-36).

The final stanza, A', returns to the lighter flippant mood of the beginning, but the thought of "death" muddies the ending. The last phrase is written in full voice, instead of sprechstimme, giving a weight to the statement that was not there in the beginning. This full-voice ending paired with the contrasting dynamics and extreme range discrepancy in the accompaniment is successful at both highlighting the last line of text and giving the listener a definite and abrupt ending, effectively eliminating the whimsy and frivolous nature felt at the onset.

As mentioned above, Rochberg's aim is to highlight the satire and whimsy in Blake's poem. He achieves this through text painting, flutter-like accompanimental figures, and overall wide-ranging intervallic leaps and varied dynamics. Unlike Britten, who retains the same underlying flippancy from beginning to end, Rochberg's satire gets progressively 
darker through the course of the piece. The abrupt changes in the B section from carefree, almost frenzied, dance to melancholic casualness, to deep philosophical musings on death paint a vivid picture of the speaker's very "human" thoughts. There is also formal significance in Rochberg's manipulation of the serial material. For example, the penultimate stanza (measures 26-32) is the only section where the voice does not have a complete row presentation. This can be viewed, perhaps, as an unraveling of the speaker's previous over-confidence (manifested in complete rows) giving way to a solemnity in thought not previously experienced. Another example of Rochberg's interpretive maneuvering is the parallelism between measures 1 and 37 . There is a shift in mood at the return of the A section with a slightly different vocalization of the initial row. Here, Rochberg repeats almost all of the accompanimental figures that are present in the first part of the A section, with the only main difference in the ending of the piece (measures 4142), where the flute and cello function as cadential material, sounding an F\#- F - A - A b I0 tetrachord and a descending B $-\mathrm{C} 7^{\text {th }}$, respectively. The vocal line similarly reflects a cadential-like arc, substituting the breathless accented sixteenth-notes in measures 3-6 with augmented rhythms mirroring the text. An elongated sprechstimme A $b 5$ sliding down a major $7^{\text {th }}$ to $\mathrm{A} \sharp 4$ on "I live" is followed by four full-voice eighth-notes beginning on an offbeat (an augmentation of the sixteenth-note figures often heard in the accompaniment). The sprechstimme A b - A घ in measure 40 ironically (and perhaps quite depressingly) colors the phrase, "I live," especially when compared to the full-voiced ending eighth-notes immediately following. It is as if the speaker has already given up on his life with the knowledge that the only thing that is truly certain is death, hence the separation between indistinct tones, or sprechstimme, on "I live," and pure, full sounds on "I die." The steady 
eighth-notes, then, symbolize this inevitability of death that is realized by the speaker and brings the piece to a melancholic, rather than flippant, end. While the piece is rooted in serial techniques with inter-connections of intervals, rhythms, and row permutations, Rochberg's individual interpretation of Blake's poetry shines over the technical complexities, creating a unique amalgamation of method and sensation. 


\section{"The Lamb" \& "The Tyger"}

THE LAMB

$1 \quad$ Little Lamb, who made thee?

Dost thou know who made thee?

Gave thee life, \& bid thee feed

By the stream \& o'er the mead;

5 Gave thee clothing of delight,

Softest clothing, wooly, bright;

Gave thee such a tender voice,

Making all the vales rejoice?

9

Little Lamb, who made thee?

Dost thou know who made thee?

11 Little Lamb, I'll tell thee, Little Lamb, I'll tell thee:

He is called by thy name,

For he calls himself a Lamb.

15 He is meek, \& he is mild;

He became a little child.

I a child, \& thou a lamb,

We are called by his name.

19 Little Lamb, God bless thee!

Little Lamb, God bless thee!

\section{THE TYGER}

Tyger! Tyger! burning bright

In the forests of the night,

What immortal hand or eye

Could frame thy fearful symmetry?

5 In what distant deeps or skies

Burnt the fire of thine eyes?

On what wings dare he aspire?

What the hand dare seize the fire?

9 And what shoulder, \& what art, Could twist the sinews of thy heart? And when thy heart began to beat, What dread hand? \& what dread feet?
13 What the hammer? what the chain?

In what furnace was thy brain?

What the anvil? what dread grasp

Dare its deadly terrors clasp?

17 When the stars threw down their spears, And water'd heaven with their tears, Did he smile his work to see?

Did he who made the Lamb make thee?

21 Tyger! Tyger! burning bright

In the forests of the night, What immortal hand or eye Dare frame thy fearful symmetry? 
The two poems, "The Lamb" and "The Tyger," are often discussed in parallel because they offer differing views on the act of creation. As discussed in Chapter 2, Blake's religious beliefs manifest themselves as different states of mind and, when he proposes an idea in his poetry, it is not according to any "abstract criterion," but to the "qualities of the mind in association with the idea." 198 Gillham suggests that Blake's interest is in "love, not theology," and he evaluates "religious notions by asking if they demonstrate a soul capable of love or not."199 Both poems contemplate the notion of our Creator and His love for His creations. The speaker in "The Lamb," representing the state of Innocence, is unfailingly certain of the nature of the Lamb's (and his own) Creator, while the speaker in "The Tyger," representing Experience, views the Creator as incomprehensible and is only able to pose seemingly unanswerable questions.

In "The Lamb," the speaker, whom we know from the second stanza is a child (or at least identifies as a child or child-like), is talking to a lamb and explaining, with joy, the lamb's Creator. As Andrew Lincoln illuminates: "The child may be repeating a lesson taught by an adult, but his understanding of the maker is expressed in his own delight in the Lamb." 200 In the first stanza, the maker demonstrates his love for the Lamb through giving it life and food, protecting it with "wooly" clothing, and rejoicing in its "tender voice." The question at the beginning, "Little Lamb, who made thee?," is knowingly answered in the first line of the second stanza, when the speaker repeats "Little Lamb, I'll tell thee." The child's sense of identity with both the Lamb and their Creator reveals itself here, where a connection is made between "He" and the "Lamb" and "He" and the "child," thus evoking a

198 Gillham, Contrary States, 223.

199 Ibid.

${ }^{200}$ Lincoln, commentary, 147-8. 
sense of familiarity and companionship that the speaker feels between the three beings. This culminates with the ending couplet of the speaker blessing the Lamb, where essentially the speaker believes that his blessing of the Lamb is really God's blessing; His divine love passes through the child to the Lamb.

While the speaker in "The Lamb" exudes an obvious truth that the Creator of his world was gentle and loving, "The Tyger" is not so confident in His nature. The setting for the Tyger's creation is the "distant deeps" and "skies," suggesting a place beyond space and before time where a "mysterious Being" undertook the animal's creation. ${ }^{201}$ Unlike the speaker in "The Lamb," who was so sure of his understanding, here, the speaker can do little but wonder at the genesis of the terrifying and awesome beast before him. The act of creating the Tyger is a violent and strenuous undertaking, suggesting not a gentle and loving Creator, but one who is strong and willful. A Creator whose "triumph of will" in hammering, twisting, and chaining the Tyger into existence is embodied in the Tyger itself, with "heart-beats [that] echo the beat of the creator's hammer, and whose eyes and body burn like the fires of the furnace."202

The question of whether or not such a maker could create both a ferocious Tyger and a gentle Lamb comes to a climax in the penultimate stanza of the poem. Here, the speaker forgoes his awestruck questioning for a more human speculation of the nature of the Creator. In the first two lines of the stanza (lines 17-18), the Tyger's creation seems to have even overwhelmed the "stars," who throw down their "spears" and weep in pity or regret at the beast's existence, and leave the speaker to wonder how or if the Creator could be pleased with his work. D.G. Gillham offers this insight: "...if the Creator can smile it

201 Gillham, Contrary States, 242.

202 Lincoln, commentary, 187. 
is...either because He knows more than the stars and can see a place for this new creature in the light of His superior understanding, or because the sight of the voracious tiger appeals to His inscrutable nature."203 The question remains unanswered, as do all the others posed in the poem, and the Creator remains inconceivable to the speaker through the end of the poem. This quite terrifying personification of our maker does not, however, force a symbolic representation of evil on the Tyger. Upon reading the poem, one becomes primarily aware of the immense power and beauty of the animal. In a way, the speaker's view of the Tyger in this uniquely crafted and awe-struck way is liberating, as if there are things that still exist in this world that defy order and that are capable of transcending the structures of society.

There are similarities in the poetic structures of "The Lamb" and "The Tyger," both contributing to their meaning and interpretation. The poems have the same rhyme scheme of AABBCC, and so on, with lines constructed of 6-8 syllables. Both are written in predominantly trochaic feet (stressed-unstressed), which, as was discussed in Chapter 3, is a reversal of the more "normal" iambic stress of English speech and poetry. The trochees of "The Tyger" form a primal rhythm that becomes so prominent "it overrides the actual language rhythm."204 For example, the second line by itself could be read:

Inn thĕ fórests ŏf thĕ níght vs. Ín thĕ fórĕsts óf thĕ níght But the initial strength of the trochee rhythm has already been established and carries the remainder of the poem with it. The rhythm intensifies as the poem continues, with strong "initial" trochees occurring in the middle of lines in the fourth stanza:

203 Gillham, Contrary States, 244.

204 B.H. Fairchild, Such Holy Song: Music as Idea, Form, and Image in the Poetry of William Blake (Kent, Ohio: Kent State University Press, 1980), 37. 
Whát thĕ hámmĕr? Whát thĕ cháin?

These instinctive, organic, and visceral stresses echo the wonderment and sublime nature of the poem's theme. Because the trochee is sustained throughout the poem, its "unusualness" against the "normal" iamb is intensified. However, "The Lamb" also employs sustained trochee stresses and the effect is quite different from the powerful, ferocious Tyger.

In "The Lamb," trochaic stresses exude a child-like, rather than primitive, rhythmic environment reminiscent of nursery rhymes and songs. Here, the rhythms lull the reader into a world of "unblemished goodness and completeness," with soft consonants and long vowels intensifying the "fragile purity of innocence." 205 Like "The Tyger," there are instances of initial trochees in the middle of lines, but, while the former's purpose is to evoke intensifying awe and terror, the latter's is to build warmth and unity:

$$
\text { Hé iss méek, \& hé ǐs míld; I I ă chíld, \& thóu ă lámb, }
$$

The visual images that accompany the poems are not as easily comparable and offer very different representations of their respective poems. The design for "The Lamb" provides a "visual equivalent of the song's child-like vision of divine protection."206 The pastoral scene of a naked child holding out his hand to a lamb is "sunny and peaceful."207 The lush vegetation on the tree in the background, the warm golden color of the thatched roof, and the number of sheep suggests a picturesque, healthy, and abundant existence for the child and his animals. Two slender vines curve up to form a high arch serving as both a

205 Fairchild, Holy Song, 38.

${ }^{206}$ Lincoln, commentary, 148.

207 Ibid. 
frame for the scene below the text and also adding a layer of "protection" over the child. ${ }^{208}$ There are several elements, however, that seem to possibly question the unfailing sense of peace exuded by the poem. There are dark patches in the sky above the roof and up the left side of the plate, and, while the tree within the scene is vibrant, the vines enveloping the text and scene are bare and appear fragile, perhaps not providing as much security as first thought. However, the abundance of warm colors and the details and full textures of the scene give the image an overall sense of tranquility.

"The Tyger's" image seems at odds with the speaker's "breathless struggle" for Divine comprehension. ${ }^{209}$ There are two main subjects in the image: the tyger below the text and a great tree rising up the right hand side of the plate. The colors of the tree are light, especially compared to the brightness of "The Lamb," which seem to contrast with the setting of "the forests of the night." The branches of the tree are bare and snake out to differentiate most of the stanzas. The Tyger itself is stocky and appears static; definitely not the threatening, ferocious beast alluded to in the text. ${ }^{210}$ With a wide eye and almostsmiling mouth, one cannot help but feel a sense of contradiction or duality between the image and the text. Like in "The Lamb," there are hints at different meanings within the image. The Tyger's body appears to be lit from below (contradictory to where the sun would normally hit) with dark shadows cast along its back, and dark blue splotches of sky shadow the tree and the upper part of the plate, perhaps giving a taste of the supposed

\footnotetext{
208 Ibid.

209 Ibid., 188.

210 The image referenced here and in the appendix is an earlier issue of the Songs. In later issues, the Tyger appears more ferocious with darker colors and a snarling mouth. However, there is a general consensus among critics that, no matter the version, the overall effect of the image is not entirely in line with the vividness and wonderment of the text.
} 
demonic genesis of the beast. ${ }^{211}$ The overall effect, however, is one of paradoxes, as if Blake is marrying the contradictions of beauty and violence, or good and evil, within the pairing of the poetry and the visual image.

\section{VAUGHAN WILLIAMS, “THE LAMB”}

"The Lamb" is the fifth song in Vaughan Williams's cycle and is particularly pastoral and folksong-like in response to Blake's text. The piece is in AA' form with each section containing four antecedent-consequent groups plus a couplet, corresponding to the poem's written shape. The piece exudes pastoral idioms ranging from the F natural minor tonic, sounding an homage to the organicism of the folk-song tradition, to the abundance of melismatic writing and an obbligato oboe line that evokes the image of playful, independent lamb. The overall modal structures are kept simple with phrase groupings moving from tonic ( $\mathrm{F}$ natural minor) to the minor dominant ( $\mathrm{C}$ natural minor), subdominant ( $\mathrm{B} b$ natural minor), or mediant ( $\mathrm{A} b$ major). The focus remains on the interplay between voice and oboe and on the purity and natural innocence embedded in the melodies.

One of the main musical characteristics present in "The Lamb" is the independence of the oboe line. During the first vocal phrase, the oboe and voice are in a miniature calland-response relationship. The oboe begins a brief 4-beat introduction of a melismatic turn figure before the voice enters with a similar inverted line making up the first phrase pair. The two converge briefly and somewhat heterophonically at the end of measure 5 through measure 7, though never exactly meeting until the first two beats of measure 7, before the oboe takes off seemingly on its own in the second half of measure 9, as if the lamb came to

${ }^{211}$ Lincoln, commentary, 188. 
greet the child before running off to play. The next antecedent-consequent phrase ends in C natural minor at the beginning of measure 9 (as confirmed by the $D^{\natural}$ ), though the cadence is short lived with the passing $\mathrm{D} \sharp$ in the oboe moving right back to tonic in the next beat.

The next four vocal phrases keep a similar structure with 4-bar phrasing and brief cadences moving from tonic to the mediant and then to the subdominant. The two phrase pairs before the final couplet of the first half essentially repeats vocally the middle phrase (measures 9-13), with an embellished vocal line leaping up to F5 before sounding an elongated descriptive melisma on "rejoice." The oboe echoes the voice's figure and augments it further, connecting back to tonic for the final couplet of section A. Here, Vaughan Williams alters the rhythm of the opening text and changes the emphasis of the line from "made," on the downbeat in measure 2, to "who," now on the downbeat in measure 20. This simple change leads the listener into the next stanza of text, where the speaker knowingly reveals the answer to this question.

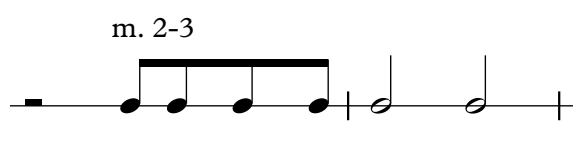

Lit-tle Lamb, who made thee?

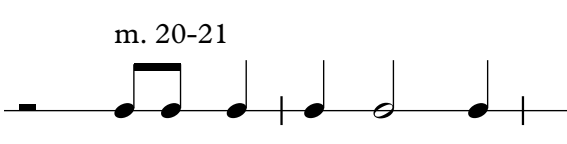

Lit-tle Lamb, who made thee?

Example 12: Vaughan Williams, “The Lamb," Rhythmic Reduction, measures 2-3 \& 20-21

Generally speaking, the second half of the piece employs a greater number of melismatic figures and further explores the mediant key of $\mathrm{A} b$ major. The oboe takes on a larger role in the $\mathrm{A}^{\prime}$ section and leads the voice into new modulations. Its introductory figure is transposed down a minor third in the second half of measure 24 to begin on B b , instead of D, and therefore ends on the third of the F minor tonic triad. The voice follows the oboe's lead, but moves up a minor third to begin its first phrase on A $b$, instead of $F$. The oboe continues to direct the phrase to arrive in $\mathrm{A} b$ major in measure 28 at the end of the 
first couplet of the second stanza. Because the confirmation of this tonic takes place on a weak beat and at the end of a phrase, the listener does not necessarily feel a grand "arrival," but senses, rather, an almost illumination of the new key as it subtly blossoms from the oboe. The "la-ti-do" (F - G - A b ) movement in the oboe in measure 28 arriving on the goal note on beat three, expertly foreshadows the arrival of "He" in the next measure, as if the oboe somehow already knows the answer to the question the voice is posing. Vaughan Williams is able to create a climax at a significant point in the poem (when the speaker names their creator) without disrupting the flow and organicism of the "folk-song" structure.

The section continues with the voice staying relatively close to the phrase arcs of section A, while the oboe explores new melodic expressions. The only instance of a direct parallel in both instruments is seen in measures $35-37$, which is a repeat of measures 1113. From that point forward, the voice retains the same melodic structure as the first section. The oboe, however, branches out again and directs the voice back into a major tonality beginning in measure 38 . An $\mathrm{E} b$ major rising scalar passage in measure 40 introduces an oboe climax on A b 5 (reminiscent of the passing A b in measure 28), which dissolves into a sequential descent leading to the final couplet of the poem. The last two lines of text echo the rhythmic form of section A, but now the voice rises for its final notes to the $5^{\text {th }}$, instead of the tonic, and leaves the oboe to finish the piece. This Coda begins with the opening four-note figure, suitably transposed, followed by a figure only previously heard in measure 18, then its inversion - never previously heard - concluding on tonic. The main musical motive in "The Lamb" is the oboe's turning 4-eighth-note figure consisting of a combination of 2 steps and a leap. The oboe introduces it in the very 
beginning and employs the figure throughout the piece. Along with the occasional held "drone-like" note in the oboe, this figure is the prime pastoral element in the song. The voice occasionally echoes the oboe's turning figure (as in measures $3,14,27,30$, etc.), but often sounds syllabic or melismatic figures based on ascending or descending scales. The use of text-painting or descriptive musical elements is not overt, but embedded subtly in the movements of the instruments. For example, the use of extended melismas in measures 16-17 and 40-41 effectively reflect the connotations of the corresponding texts. The melisma in measures 16-17 is on "rejoice," not only embodying the joyful meaning of the word, but also correlating to the Lamb's "tender voice" that is being lauded, as if the singer is celebrating the Lamb's voice with the expansion of his own vocal line. The parallel instance of the melisma, in measures 40-41, symbolizes a similar joyfulness, this time relating to the unity that exists between singer, Lamb, and God. Like the previous occurrence, the melisma both emphasizes the importance of the words, "His name," while also acting as a jubilant outburst progressing from the previous two phrases.

Apart from the changes in stress between the first and last couplet, which was discussed above, another example of slight rhythmic alteration as a way to reflect the text is evident in measures 33-34. Here, Vaughan Williams composes a vocal phrase of six steady quarter notes for the line, "He is meek, and He is mild:," rather than adding variation with dotted quarter- and eighth-notes as he does for the parallel phrase in the first section (measures 9-10). The steadiness of the line (the longest phrase without eighth-notes or dotted rhythms in the piece) illustrates the calm simplicity of the words "meek" and "mild," and is highly effective when contrasted with the two surrounding melismatic passages. 
Being arguably one of Blake's most well-known poems (along with "The Tyger"), it is not difficult to imagine the traps of setting "The Lamb" to music: focusing too much on either the religious or pastoral themes, falling victim to the monotonous nature of the trochee rhythm, or calling too much attention to the structured rhyme scheme. Vaughan Williams, however, seems to negate all of these preconceived difficulties and creates a piece that is as charming as it is reverent and as multifaceted as it is hummable. When one listens to "The Lamb," one vividly imagines the oboe as an innocent creature frolicking in the field, not quite ever settling near the singer, but content to coexist and listen to the speaker's beautiful melody.

\section{BRITTEN, “THE TYGER”}

"The Tyger" is the fourth and central piece in Britten's cycle (following "The Poison Tree") and, for the first time, its preceding proverb is not introduced with a piano flourish. The text is taken from No. 41 of the "Proverbs of Hell," and offers an interesting contrast and introduction to the wild Tyger.

Think in the morning. Act in the noon. Eat in the evening. Sleep in the night.

The oddly ordinary phrases are introduced by marching quarter notes in the bass clef. Without the piano's pronouncement flourish, the listener finds themselves "more or less immersed in this aphorism before [they] quite expect to be there."212 The vocal part continues the progression of the other proverbs by being more melodic in nature, sounding almost all twelve-tones (minus B and C) within the four 3-note lines. Unlike the other proverbs, the piano and voice are often in direct relation to one another: all three melody

${ }^{212}$ Meister, "Interaction," 113. 
notes of the first vocal line and at least the long initial tone of the other phrases are drawn from the 4-note groupings of their respective accompaniments. ${ }^{213}$ The dynamic range is small, rising only to $m f$ from $p p$ and ending with a decrescendo into the song proper. All the musical and textual elements in this proverb (the seemingly banal statements, structured marching piano, relatively consonant harmonies, and slight dynamic differences) are either an attempt to lull the listener into a false sense of security, making the introduction of the terrible Tyger that much more tremendous, or purposefully drawing an ironic connection between the two entities (the same person who says that is also capable of thinking this...). Graham Johnson suggests that the final line of text is the key to the connection: "The fourth proverb...introduces the idea of 'Sleep in the night;' with sleep comes dreams, and with them the exotic idea of the tiger."214 If one notices the pitch construction, the importance of the change to sleep and night becomes even more significant. The first three phrases follow the pitch pattern: $\mathrm{E} b-\mathrm{F} b-\mathrm{D} ; \mathrm{F} \#-\mathrm{G}-\mathrm{F}$ ; $\mathrm{A}-\mathrm{B} b-\mathrm{A} b$. Continuing the ascending halfstep/descending whole-step figure, the final phrase should be $\mathrm{C}-\mathrm{C} \#-\mathrm{B}$, which would complete the aggregate. Instead, the melody is inverted to descending half-step/ascending whole-step (D - C\#- D\#), disrupting the progression and foreshadowing the unexpected frenzy that is "The Tyger."

As discussed above, "The Tyger" is one of Blake's most recognized poems, creating a difficult task for composers who attempt to set it to music. The poem's rhythms, accents, cadences, etc. are just as structured and memorable as those of "The Lamb," but the composer must also combat with the vast amount of criticism and varying interpretations written about “The Tyger." Britten's setting concentrates on the ferociousness and

213 Ibid.

214 Johnson, Britten, Voice and Piano, 215. 
awestruck sublimity of the text without bringing into question the possible contradictions arguable within the accompanying visual image. The piano introduction begins by continuing the chromatic ascent of the last measure of the proverb. The combination of Britten's "quick and muted" marking at the beginning with the figures in the piano (rising eighth-notes in the left hand and triplet sixteenth- and eighth-notes in the right) creates a feeling of "rapid, stealthy movement."215 The opening measures are more consonant than the previous pieces, and incite multiple tonal/modal interpretations. Both the accompaniment figures begin on the same note (E\#) and measure 1 essentially sounds an ascending $\mathrm{F} \#$ major scale, the dominant of the proposed key signature of $\mathrm{B}$. The $\mathrm{E} \#$, however, also suggests the possibility of a B Lydian scale, which becomes more plausible with the alteration to $\mathrm{E} \boxminus$ in the right hand ( $2^{\text {nd }}$ eighth-note) in measure 2 , quickly changing the mode to a tonal B Major before changing back to E\# in the last sixteenth-note of the measure. The energy of the first two measures culminates in a diatonic tone cluster in measure 3. The cluster could suggest either a bitonal tonic-dominant relationship between B Major and F\# Major, or points again to the more probable B Lydian modality. The vocal line, however, further muddies things with the first two vocal phrases seemingly in $\mathrm{D} \#$ minor (D\#-E\#-F\#-G\#), relating more to $F \#$ Major than B Lydian. Regardless of the exact modal/tonal analysis, the ambiguity and quiet fierceness of the opening of the piece vividly depicts Britten's interpretation of Blake's inconceivable beast.

RH Piano:

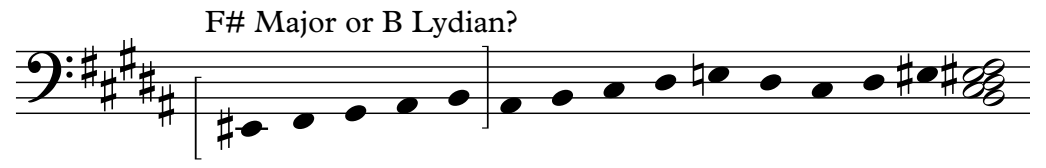

215 Meister, "Interaction," 120. 
LH Piano:

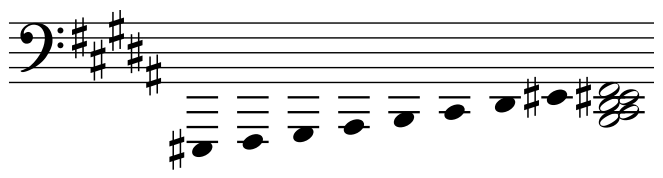

Example 13: Britten, "The Tyger," measures 1-3 Reduction

One of the main characteristics of the vocal line throughout the piece is syncopation, evident at the start of the opening phrase. Phrases beginning on off-beats and/or weakbeats both lessens the strength and precarious monotony of the trochee rhythms, and conveys a fearful hesitation in the speaker. The result is occasional explosions of "constrained nervous energy, as though the singer has been holding his breath in terror."216 The first stanza is set as a miniature AA', with a descending melodic arc for the first two lines and slightly altered ascending phrases for lines 3 and 4 . Britten deemphasizes the different pronunciation of "symmetry" (which ends with "tree" rather than the correctly rhymed, "try") in "What immortal hand or eye / Could frame they fearful symmetry?" by keeping the questioning phrase tied to its opening counterpart (measures 9-12) through a semi-inverted line, reserving the real build of inquisitive tension for the second stanza.
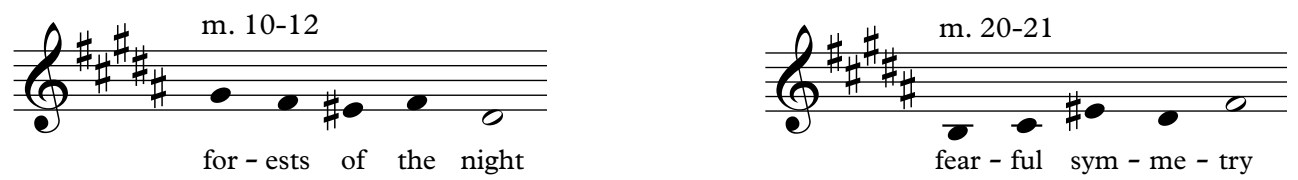

Example 14: Britten, “The Tyger," Vocal Line Reduction, measures 10-12 \& 20-21

Poetic stanzas dictate the form of "The Tyger," with each stanza/section containing both parallel musical elements and unique figures reflecting the text. Britten employs breath marks in the piano throughout the piece, similar to those in "London," both within stanzas and at cadential points differentiating between sections. The musical stanzas are

216 Meister, "Interaction," 121. 
fairly symmetrical, with the exception of Stanza 1, which is longer due to the piano introduction. The delineation, with total duration of each section in parentheses, is as follows: Stanza 1 - measures 1-23 (23); Stanza 2 - measures 24-40 (17); Stanza 3 measures 41-56 (16); Stanza 4 - measures 57-73 (17); Stanza 5 - measures 74-92 (19); and Stanza 6 - measure 93-111 (19). The first three stanzas end on held half-notes, either with voice and piano sounding together or piano alone. Stanzas 4 and 5 both culminate in a full measure of silence before continuing into the next phrases. The final stanza returns to the cadential half-note hold, ushering in a twelve-bar postlude in the piano that brings the piece to an attacca end segueing into the next Proverb.

Musically, Stanza 2 continues the upward trend that was introduced in Stanza 1, with parallel phrases coinciding with every two lines of the poem. In terms of pitch content, Stanza 2 moves away from the B Lydian modality/D\# minor vocal line set by the previous phrases to octatonic vocal phrases beginning in measure 33 and ending with an octatonic tone cluster built on $\mathrm{F} \#(\mathrm{~F} \#-\mathrm{G} \#-\mathrm{A}$ 日 $-\mathrm{B}-\mathrm{C}$ 日) in measure 40. The general upward motion of the first two stanzas is reversed for Stanza 3, with the music now concentrating on the twisting "sinews" of the Tyger's heart. The piano accompaniment elongates the stalking opening figures underneath the Stanza 3 phrases, while the staccato repeated notes on "when thy heart began to beat" add a text-painting rhythmic touch to the penultimate line. The tone cluster releases return for the final phrase of the stanza, this time coming more quickly as there are now two questions within one line of text. The clusters echo the musical content of the previous two stanzas, ending first on a B Lydian collection (B-C\#-D\#-E\#-F\#), then a D\# octatonic collection (D\#-E\#-F\#-G\#-A). 
As the questions come more rapidly in the fourth stanza, Britten builds the tension with ascending vocal lines and quickly-shifting octatonic harmonies. Melodically, measures 57-63 ("What the hammer? what the chain? / In what furnace was thy brain?") are essentially a repeat of measures 33-40 ("On what wings, dare he aspire? / What the hand dare seize the fire?"), but harmonically, now combine the D\# octatonicism of the previous phrase with the F \# octatonicism first heard in measure 40. Britten continues to build on the vocal ascent for "What the anvil? What dread grasp," rising to a climatic E b on "Dare its deadly terrors clasp?" by way of a "masterful use of harmonic screw-turning."217 The piano supports the long held note with its agitated introductory figure, moving from E\# octatonic (measures 67-69) to A octatonic (70-72), but ends abruptly, without the cluster chord, ushering in almost two full bars of silence. The constant shifting of octatonic harmonies paired with the relentless piano rhythm and ascending, syncopated vocal line create a cacophonous musical climax that highlights the anxiety embedded within the questioning text.

The pause allows Britten to completely reverse the direction of the piece for Stanza 5. Previously, the piano and vocal lines moved in a general upward arc. Now, with a key signature change from B major to E b major and a complete opposite dynamic marking $(s f$ to $p p$ ), all melodic motion moves downward. The same piano figures that depicted the stealthy movement of the Tyger and the twisting sinews of its heart now morph into plunging cascades, in both piano and voice, that audibly express Blake's imagery of falling tears. As Graham Johnson points out: “The accompaniment, which has momentarily moved

217 Johnson, Britten, Voice \& Piano, 216. 
to the higher reaches of the keyboard for the first time, falls earthward under the fingers of a pianist whose cascades of descending scales must be as light as stardust."218

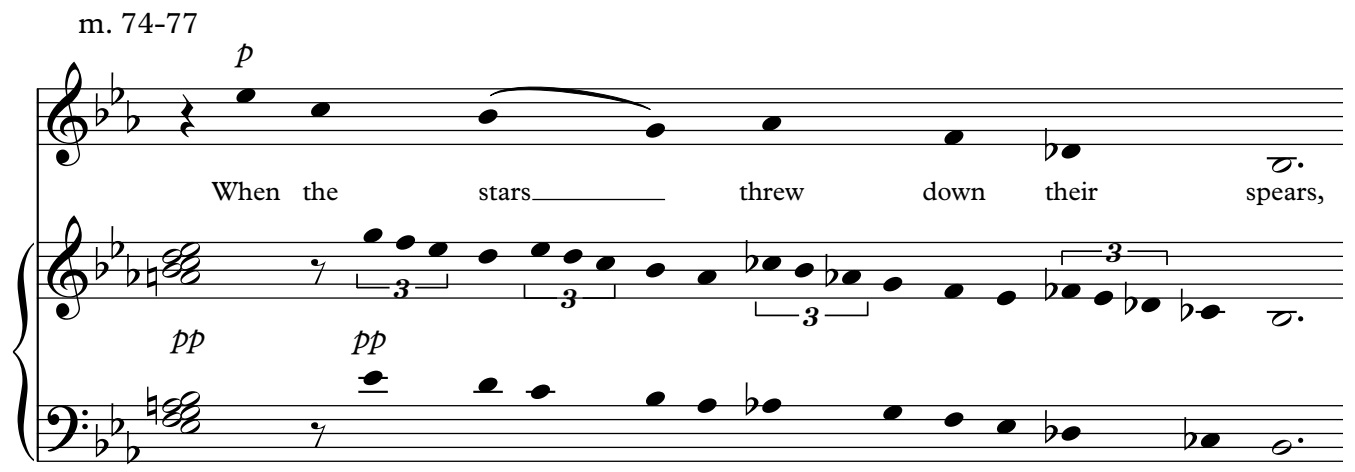

Example 15: Britten, "The Tyger," measures 74-77 Reduction

The order of the piano figure is also reversed, now beginning with a tone cluster, which introduces the subsequent sixteenth-/eighth-note movement (instead of vice-versa as before). Similar to the opening, Britten writes a Lydian tone cluster, this time beginning on $\mathrm{E} b$ and consisting of the full scale (with the A - B interval overlapping between the left and right hands in the piano): $\mathrm{E} b-\mathrm{F}-\mathrm{G}-\mathrm{A} \bullet-\mathrm{B} b-\mathrm{C}-\mathrm{D}-\mathrm{E} b$. Also reminiscent of the beginning of the piece, the first two lines of Stanza 5 are written in parallel phrases with the same underlying harmony in the piano. However, Britten shifts the ending note up a half-step for the second phrase, ending on a $\mathrm{C} b$ instead of $\mathrm{B} b$, an alteration that is repeated for the final two lines of the stanza (though up an octave and written as B versus $\mathrm{C} b$ ). These two pivotal questions at the end of the fifth stanza, "Did he smile his work to see? / Did he who made the Lamb make thee?," are sung in low, hushed tones with rhetorical pauses written in ascending held notes between each phrase. Johnson regards these phrases as "masterful" connectors into the final stanza:

218 Ibid. 
Just the right amount of rhetorical pause is built into the music after each of the questions, and the musical sequence, where the second of the questions is placed at a higher pitch than the first, engineers a recapitulation that is so perfectly set up that one simply smiles at Britten's sovereign - and unashamedly conventional - control of his resources. ${ }^{219}$

The final stanza is almost an exact repeat of the opening lines, with one significant alteration: where Blake substitutes "dare" for "could" in the first verses, Britten "breaks his rule" of syllabic setting and gives the singer three descending quarter notes on the "allimportant" verb. ${ }^{220}$ This is a prime example of the power of a musical imagining of poetry. In the written poem, Blake has no immediate way of calling attention to the word change, it is up to the reader to both notice it and decide if it is of interpretive significance or not. In music, however, a composer has an almost infinite number of devices to call attention to whatever details in the text they see fit to emphasize. In Britten's interpretation of "The Tyger," it is almost impossible to not hear the difference between the final lines of the first and last stanzas and, in turn, recognize the significance and literary progression of the two words. A 12-bar postlude, one of the longest in the cycle, echoes the quick turning figures and held tonal clusters characteristic of the piece. The piano figures "move in impatient circles," possibly evoking the image of a caged big cat ready to pounce or even stalk away as the music ends as hushed and secretly as it begun. ${ }^{221}$

Both Vaughan Williams and Britten are extremely successful in translating the nuanced complexities in Blake's most well-known works. Neither composer falls into the clichéd traps each poem inevitably sets after years of recitation, criticism, and cultural adaptations. Despite the obvious contradictions and oppositions evident between the two

219 Ibid.

220 Meister, "Interaction," 123.

${ }^{221}$ Johnson, Britten, Voice \& Piano, 216. 
poems, the composer's approaches to setting them are quite similar. Both choose unifying accompanimental figures that remain consistent through most of, if not the entire, setting. The turning oboe figure that begins "The Lamb" is worked over constantly, the instrument hardly ever resting, with a total of only 4 beats of rest through the entire piece. Britten's introductory piano figure is similarly turned over and over again and varied to fit the changing mood of the poem. Both figures act as an audible constant, grounding the listener and enabling the subtleties of the text to remain the focal point of such vivid (often stereotyped) poetic imagery. Another main similarity between both compositions is the treatment of the trochee rhythms. Both composers choose to set the strong initial poetic stresses on weak beats. In "The Lamb," the effect is an organic intertwining of voice and oboe, conversing through melodic ideas rather than rhythmic pulses. The lack of strong initial beats in "The Tyger" makes it no less terrifying - actually, the opposite is true, as if the singer is so awe-struck by the fantastical sublimity of the beast that he cannot gather himself enough to sing on the downbeat.

As we will see in the final analysis, all three composers lend their unique styles and interpretations into setting "Ah! Sunflower" with much differentiation and success. Arguably, however, no two settings better encompass the nuanced complexities, vivid imagery, and original poetic intent of the texts than Vaughan Williams's "The Lamb" and Britten's “The Tyger." Their compositional styles are perfectly matched to the poems: rustic folk expressions bring "The Lamb" to life without being stereotypically "pastoral," and the sneakily consonant but tone-clustery Tyger is the perfect amount of text painting without the need for overtly primitive or animalistic styling. Once heard, it is hard to imagine these poems set to anything but this music. With poetry that is often so recognizable and stand- 
alone, these settings are rare instances where poetry and music truly meld together in a complete artistic synthesis. 


\section{"Ah! Sun-flower" \\ 1 Ah, Sun-flower! weary of time, Who countest the steps of the Sun, Seeking after that sweet golden clime Where the traveller's journey is done; \\ 5 Where the Youth pined away with desire, And the pale Virgin shrouded in snow Arise from their graves, and aspire Where my Sun-flower wishes to go.}

The final analysis addresses a poem about preoccupations and wasted expectations. It is a commentary on humanity's nature to always look to the future, so much so that we forget to enjoy to the present. "Ah! Sun-flower" is made more poignant when considered in conjunction with another of Blake's well-known verses, "Eternity" (see page 24):

He who binds to himself a joy

Does a winged life destroy

But he who kisses the joy as it flies

Lives in eternity's sun rise (E470)

The Sun-flower believes that the "joy" it so longs for is "not even one that is in sight, but one that is always to be."222 The Sun-flower spends its days looking up to the sun, and dreams of something that can never be reached, not only because it is an insurmountable feat, but especially since this "traveller" is rooted to the ground. The description of the Youth and Virgin "pining away with desire" suggests a life lived without any real fulfillment, because they, too, were filled with constant expectation. Barbara Meister offers this succinct interpretation:

...the Sun-flower seeks to escape the natural order to find a more perfect existence, presumably one attainable only after death; the Youth and Virgin have met death because they have denied their sexuality which of course is part of the natural order. Nevertheless the three protagonists aspire

222 Gillham, Contrary States, 210. 
to the same "sweet golden clime / Where the traveller's journey is done." As is his wont Blake leaves us with as many questions as answers!223

To emphasize this unattainable contentment sought by the subjects, Blake uses only subordinate clauses in the poem with no main action verb "in the long sentence...because nothing is ever to come to a resolution."224 The one verb, "aspire," in the penultimate line reinforces this impression by implying the continuation of the subject's longing - they have not made it to the place of rest even from their graves.

There is ambiguity in the speaker of the poem, which is not surprising considering the other poetry in the Songs. There are essentially two ways of thinking about who is speaking: 1. it is another of the Songs personae relating to the flower and commiserating in sincerity, or 2. it is Blake's own voice ironically chastising the discontented flower. Both interpretations are textually valid, though the latter seems more complete. The opening sigh could suggest the speaker feels the same weariness attributed to the Sun-flower ("a suggestion emphasized by the heavy stresses in the song"), and the "wistful" tone may steer the reader into sympathy for the "time-bound" victims. ${ }^{225}$ However, an ironic reading is a bit more probable, especially when absorbing it through modern eyes, making it quite easy to imagine Blake reciting this to himself as he walked the streets of London. The opening sigh becomes one of disappointment or, for lack of a better analogy, like saying: "Ah! Sunflower...bless your heart, but you have got it all wrong..." Read in this way, each subsequent image, then, takes on an ironic touch: the "sweet golden clime" suddenly becomes knowingly not so "sweet," the Youth and Virgin "pining away" take on a darker symbolism, chastising the morals and cultures that forbid them to live their lives in contentment, and

223 Meister, "Interaction," 139.

224 Ibid.

${ }^{225}$ Lincoln, commentary, 189. 
the lack of a concrete idea of where the subjects want to go (obviously it is some kind of after-life) suggests that the place they are hoping for is not exactly what they imagine it to be. While the opening lines allow the possibility of pity for the Sun-flower, the apparent irony inevitably sets in and taints the feeling towards the "dedicated flower whose concern about an hypothetical arrival prohibits any possibility of its traveling."226

"Ah! Sunflower" is on a plate with two other poems, "My Pretty Rose Tree" and "The Lilly," all three with flower subjects. "Ah! Sun-flower" is the middle of the three poems with the text and title appearing in a cloud-like state, unlike the others who are firmly grounded with green grass and vegetation at the bottoms. The Sun-flower is evident in the top left margin beside the title. It sits at the "top of a tightly coiled tendril" and is a "tiny golden human form of the Sun-flower, with petal-like arm, root-like leg, and hair flowing back."227 The colors are primarily warm and golden, with a bit of cooler blue in the opposite margin perhaps alluding to the inevitable nightfall that comes after each long day the Sun-flower waits. The poem can be loosely connected to the other two on the plate. The first, "My Pretty Rose Tree," tells a story of possession and pride in love and its resulting jealousy, while "The Lilly," acting as a sort-of "moral" to the story of the first two, is somewhat similar to the "Eternity" quatrain considered above.

"The Lilly"

The modest Rose puts forth a thorn: The humble Sheep, a threatning horn: While the Lilly white, shall in Love delight, Nor a thorn nor a threat stain her beauty bright.

226 Gillham, Contrary States, 211.

227 Lincoln, commentary, 190. 
Here, there is a parallel between the attitudes represented by the Rose and Sheep, and the attitudes of the speakers in the two preceding poems: "self-possession must lead to possessive relationships with others, confining desire and thus generating unsatisfied longings."228 In contrast, the Lilly represents a true love that is neither self-denying nor self-protective. 229 Unlike the speakers of the previous poems, the speaker in "The Lilly" does not use a possessive pronoun, finally signifying what a gratified love and life should be.

\section{VAUGHAN WILLIAMS}

Vaughan Williams's "Ah! Sun-flower" is one of the rare pieces in the cycle where the voice and oboe are "on the same side" and parallel each other interpretatively. We saw the oboe representing the growth of the poisonous tree while the voice told the story of their foe's demise in "A Poison Tree," and the descriptive personification of a lamb weaving around the singer's independent melody in "The Lamb," but this is the first time we hear both oboe and voice working together to communicate the same aspect of the poetry simultaneously. The oboe introduces the piece with a senza misura melody containing two triplet figures, which become connecting motives in the piece. The first of these, three quick triplet sixteenth notes at the beginning, the "grace-note" motive, appears three other times throughout the short piece - twice with the original pitch content — and its pan-flute-like sound (due to it being a segment of an anhemitonic pentatonic scale: $\mathrm{C}-\mathrm{D}-\mathrm{F}-\mathrm{A}$ ) is a main component of the piece's folk style. The second triplet motive is heard almost immediately after the first. The languid eighth-note triplet plus a quarter note (the "weary" motive) forms the main musical drive of the piece and is heard in repetition by the oboe and then

228 Lincoln, commentary, 190.

229 Ibid. 
echoed in the first vocal phrase, solidifying its importance. These two motives form the basis of "Ah! Sun-flower" and, along with the A Phrygian modality, create a somber, melancholy atmosphere for Blake's text.

The "weary" triplet is used throughout the piece both as a melodic motive (in the oboe and voice as seen above, in altered inversions such as on "countest the steps" in measure 3 and "shrouded in show" in measure 10), and as a unifying rhythmic element. Rhythmically, the triplets become a grounding point for the ear and their alterations or absences immediately call attention to that section. For example, in measures 4-7 (lines 3 and 4 of the first stanza) Vaughan Williams places "sweet golden clime" on steady quarterand eighth-notes ("a" in the example below), right after a descending eighth-note triplet. The "clime" suddenly seems laborious and slow after the ease and quickness of the triplet descent. He then furthers this feeling by augmenting the "weary" triplet to quarter-notes ("b") and doubling the rhythmic motive to two sets of eighth-note triplets back to back ("c"), highlighting the traveller's long journey.

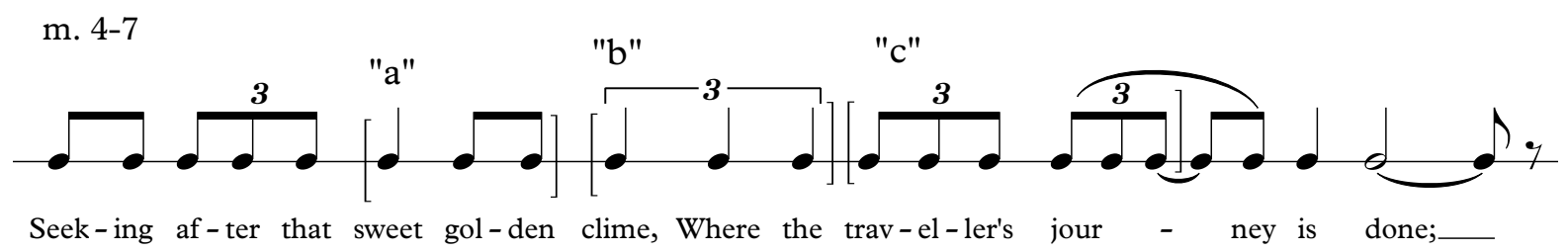

Example 16: Vaughan Williams, "Ah! Sun-flower," Rhythmic Reduction, measures 4-7

Like most of the other pieces in the cycle, "Ah! Sun-flower" is in modified strophic form (AA') with the sections mirroring the poetic stanzas. The second section of the piece begins in measure 7 with a repeat of the oboe's introductory phrase. The voice then alters its original phrase in relation to the different stresses of the poetic line. In section A, Vaughan Williams reflects the opening spondee rhythm (stressed/stressed) of "Ah! Sun- 
flower" with a quarter-note into a triplet pattern, perfectly notating the spoken rhythmic nuances of the line (he does this again in measure 4 with even quarter-notes on "seeking"). The overall anapestic rhythm of the poem does not fully set in until the last line of the first stanza ("Where the traveller's journey is done;"), but Vaughan Williams negates the singsong rhythm by elongating it with quarter-note triplets. In section $A^{\prime}$, however, a full anapestic rhythm is notated in the music with the voice's entrance for the second stanza. The even spondees disappear and the triplet rhythm now functions as a source of momentum that carries the piece to its climax in measures 11 and 12 on "Arise from their graves..."

A number of musical happenings occur in measures 10-13 that both highlight and symbolize the text. First, a rare crescendo marks the beginning of the climactic moment below the oboe at the end of measure 10 . Then, the voice and oboe move simultaneously in opposite directions, plodding steadily on quarter-notes descriptively portraying the rising and symbolic march of the Youth and Virgin from their graves. Melodically, there is an aural allusion of crossing lines beginning on the second quarter-note in measure 11 (D). Because of the tenor's octave displacement, however, the two instruments go near each other, but never fully cross. The voice reverses its initial descent by ascending to an $\mathrm{F}$ while the oboe similarly reverses its initial jump to a high $\mathrm{A} 5$ by cascading down to a chromatic $\mathrm{A} b 4$. The aural effect descriptively colors the word "graves" and the addition of the A $b$ turns the section to either F natural minor-ish or perhaps octatonic-esque. The climax ends when Vaughan Williams repeats his rhythmic augmentation (seen in measure 5 on "Where the traveller's journey...") on "aspire," echoing the length and difficulty of the Sun-flower's proposed journey in the first stanza. 
The piece comes to an end with the final line of the poem set to a descending repetition of measures 6 and 7, complete with a change to D Phrygian with the sounding of an $E b$ in the voice. The lowering of the $2^{\text {nd }}$ scale degree $(E b$ in D Phrygian) is reminiscent, again, of the cadential material first heard in London. The ending on a D final also suggests the A Phrygian opening functioning more as a dominant of D Dorian, thus keeping the D final consistent throughout the piece (see Example 17). The oboe then echoes the voice's descent, but, for the first time, has somewhat new material. Instead of repeating its opening phrase, like it did at the end of the first stanza, it sounds a descending cascade spanning over an octave from G5 to D4. The oboe retains the triplet rhythms, which anchor the piece, but raises the $6^{\text {th }}$ scale degree (in D Phrygian) to a B $ઘ$ (see Example 17), slightly altering the ending mood of the piece (and perhaps solidifying the argument of a D Dorian mode with an A reciting tone, as B $₫$ completes the Dorian scale). Rhythmically, Vaughan Williams writes out a ritardando in the oboe line, with increasingly longer rhythmic values (eighthnote triplets to quarter-note triplets to quarter-notes to held whole note) and a senza misura marking. While both voice and oboe, with their overall descending arcs, point to a melancholic disenchantment with the Sun-flower's choice of attitude towards life, the oboe hints at a possible redemption, perhaps a chance to turn around and start living in the present, with the first and only sounding of a B 4 within its final extended descent.

Modal Scales in "Ah! Sun-flower"

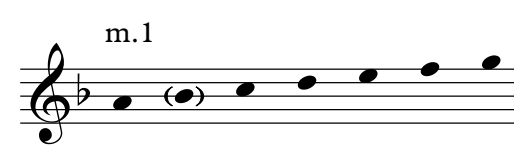

A Phrygian

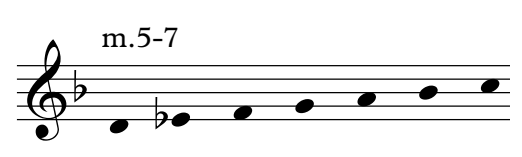

D Phrygian

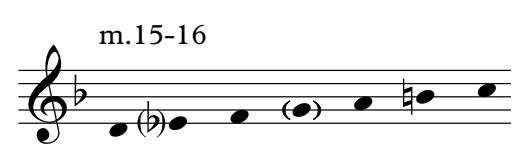

D Dorian

Example 17: Vaughan Williams, “Ah! Sun-flower," Modal Scales 
The modality, triplet rhythms, and senza misura markings give "Ah! Sun-flower" a bit of exoticism not heard before in the other pieces of the cycle. The pastoral nature of the previous pieces (especially "The Lamb" and "London") gives way to a more esoteric interpretation of Blake's words, fitting the moral thematic nature of the text. In the following two pieces, we will see similar interpretations, though the means of communicating them are quite different.

\section{BRITTEN}

For Britten, time is the central theme of "Ah! Sun-flower" and the preceding sixth Proverb. The lines of the Proverb (numbers 10, 11, and 12 from "Proverbs of Hell") are quoted in reverse of Blake's original order, effectively leading into the song proper with the last word, "time."

The hours of folly are measur'd by the clock;

but of wisdom, no clock can measure.

The busy bee has not time for sorrow.

Eternity is in love with the productions of time.

There is a connection between this proverb and the one preceding it in the song cycle (before "The Fly"). Both mention the difference between "folly" and "wisdom," with the latter essentially leading to eternal satisfaction and the former being meaningless, and both reference animals as representations of human emotions and traits. The third line of this proverb, however, is more enigmatic. If one recalls Blake's affinity for the imagination and its power to change the way we interact and observe our world, the line could be a prophetic reiteration of this sentiment. Every moment in time is as important as every other moment, and if one commits one's self to living in the present, then every moment can be eternal. 
This proverb is one of the more genius creations of Peter Pears's program. The thoughts relate not only to the ensuing song, but also to the previous "The Fly" in many ways: the "light-hearted thoughtlessness" of the hand that brushes away the fly is a form of "folly," the bee in the above proverb connects to the "flitting, buzzing nature" of the fly, and the end of the proverb, "the productions of time," carries the ear into the first line of "Ah! Sun-flower! weary of time."230 Musically, the Proverb lines differ from the other proverb settings, reminiscent of the Proverb that preceded "The Tyger" (which was the first to begin without the opening piano flourish). Britten suggests the passing of time with a "ticktock" movement in "deadpan crotchets" in the left hand of the piano, while a tremolo in the right hand possibly signifies "sand running through an hourglass." 231 The voice progresses further in melodic content over the continuous march-like repetitions of the piano. There are many instances of dissonance in the three phrases, beginning with a major $7^{\text {th }}(\mathrm{B} b$ and A) tremolo at the onset of the first line. The second proverb phrase is accompanied by another dissonant tremolo, this time inverted from its previous interval to only a half step difference, simulating the buzzing of the "busy bee." The left hand continues its march, but descends in tessitura in preparation for the third statement. As in the previous phrase, the voice begins (in its own register) on one of the notes of the tremolo, as does the left hand "clockwork," and the end of the phrase is marked by a considerable pause with fermatas. ${ }^{232}$ For the last statement, the tremolo is now consonant ( $\mathrm{D} b$ and $\mathrm{F} \#$ ), but the left-hand pattern (now reversed to ascending) creates dissonance with a tritone plus a half-step figure. The voice also adds its own dissonance with a long $\mathrm{G}$ घ set against the $\mathrm{F} \#$ in the

230 Meister, "Interaction," 135.

${ }^{231}$ Johnson, Britten, Voice \& Piano, 217.

232 Meister, "Interaction," 136. 
bass, particularly jarring on the word "love." The proverb seems to fade away unresolved, especially when a sudden quintuplet staccato sixteenth-note figure propels the listener into "Ah! Sun-flower."

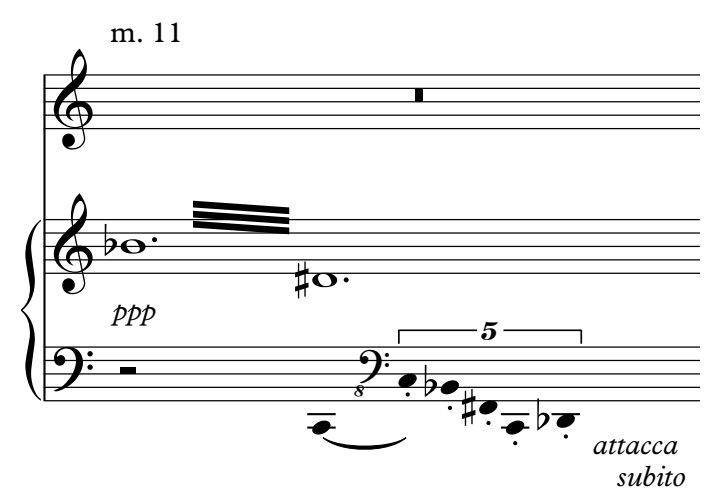

Example 18: Britten, "Proverb VI," measure 11 Reduction

The music for "Ah! Sun-flower" is some of the most lyrical and passionate of the cycle, but, ironically, it is composed of elements that rarely intertwine, forming distinct independent sounds that build the mood of the piece. The three main components are: a $32^{\text {nd }}$ grace-note figure in the right hand of the accompaniment that could be seen as a continuation of the tremolo in the Proverb, the quintuplet sixteenth-note bass figure which served as the connection between Proverb and song, and the legato, lyrical line of the voice, consisting of the principal melodic motive of a descending diminished triad (present in the opening phrase, measures 4-5).

Each element serves a specific descriptive purpose for the text. The right-hand tremolos generally ascend and suggest both "the glow of the sun and head of a tall flower shivering on its stem as it turns toward its guiding light."233 The bass line trends downward chromatically, but with the occasional octave displacement and return to a higher pitch to start a new descent. For example, the bass line moves from B0 in measure 1, to B b 1 and $\mathrm{A} 1$

${ }^{233}$ Johnson, Britten, Voice \& Piano, 217. 
in measure 4, to $\mathrm{A} b 1$ in measure 5 , and begins a new descent in measure 7 by moving back up to G1, and so on. Both piano figures create tension, with the ascending right-hand and the "lugubriously" traveling between the various harmonic points of the song relating to the "fixed points of the sun's journey across the sky."234 Against this backdrop, the voice carries its own dramatic weight through melodic motifs and lyrical expression.

Melodically, the first poetic stanza contains two soundings of the $\mathrm{C} \#-\mathrm{B} b-\mathrm{G}$ diminished triad (during the first two vocal phrases, measures 4-5 and 7-10, respectively) before changing the motive to an ascending $\mathrm{C}$ major triad depicting the "sweetness" of the "golden clime" in measure 11. The major sonority is short lived, with a crescendo into a C\# pushing the melody back to the original descending motive to close the stanza. The falling intervals of the last phrase are made all the more poignant following the optimistic ascent, dissolving any hope for a "happier" mood and foreshadowing the unattainability of the longed-for destination. ${ }^{235}$

A brief mood change in the second stanza is created with an alternating tremolo pattern in the right hand, surrounding the vocal line in sweet shimmering harmonies. Extended sixteenth-note melismas in the second phrase, "And the pale Virgin shrouded in snow," express possible empathy for the maiden whose life was ended before having known the pleasures of "earthly physical love."236 The quintuplet bass line returns in full force to accompany the first of two strong ascents in the voice signifying the rising of the subjects from their graves. The first phrase, measures 26-29, spans a fifth from A to E, while the second (after falling an octave), measures 30-33, travels a diminished $7^{\text {th }}$ from $\mathrm{E}$

234 Ibid.

235 Meister, "Interaction," 141.

236 Ibid., 142. 
to $\mathrm{D} b$ and includes an inversion of the original diminished triad motif. The strong dynamics of these two phrases, remaining in $f$ or $m f$ with crescendos, paired with the upward movement of the lines, creates a seemingly contradictory ending in relation to the previous section. Britten allows us to believe in what the Sun-flower is seeking, if only for a moment, before bringing us back to earth with a repeat of the final line, this time descending by way of the original diminished triad motive and putting to rest any naïve aspirations of the previous phrases. The 5-bar postlude is made up of the key figures heard throughout the piece, with the quintuplet march and chromatic tremolos in the piano leading "Ah! Sun-flower" into the final proverb of the cycle.

With the help of the accompanying proverb, Britten steers the listener to an interpretation of "Ah! Sun-flower" mainly colored with the concept of time. His sense of the nature of time is illustrated in even note values, repeated rhythmic figures, and contrasting subdivisions. The right-hand of the piano, with its even bell-like tones with added gracenotes or tremolos, remains constant throughout the piece, and symbolizes the enduring march of time. The repeated rhythmic figures, most notably in the quintuplet bass line, give the piece momentum, again suggesting the inescapability of the passing of time. And overtop of the unfailing piano figures is the vocal line trying to remain unique and perhaps combat the monotony of the ticking clock of time with constantly changing subdivisions of measures. Almost no two measures in a single vocal phrase have the same rhythm, with the most repeated rhythmic sections apparent in the second stanza, creating a musical connection between the Youth and the Virgin's comparable plight.

By combining these rhythmic elements with expressive writing, Britten creates a rather empathetic interpretation of Blake's poem. Unlike Vaughan Williams's setting, which 
can come across as lecture-like in comparison, Britten permits us to recognize the weariness of life and the temptation for wishing for a paradise beyond time, even if it is ultimately understood that none may exist.

\section{ROCHBERG}

Unlike the other two composers, Rochberg sets "Ah! Sun-flower" first in his cycle. In his words, "Ah! Sun-flower" expresses "the mystery of time and the world-weariness of human existence."237 This explanation offers an interesting introduction to the rest of the pieces in the cycle. Like Britten, Rochberg's setting deals heavily with the idea of time, and the serial structures in the piece naturally emphasize this theme. Similar to the other pieces in the cycle, complete statements of the row alternate with hexachords in the melodic line while the accompaniment is made up of small groups often based either on trichords of the set or seventh and ninth intervals. "Ah! Sun-flower" has a clear and fairly evenly divided form: Introduction - Stanza 1 - Interlude - Stanza 2 - Postlude. The instrumental sections (introduction, interlude, postlude) are relatively symmetrical consisting of 6 or 8 measures. The stanzas are less symmetrical, the first spanning 24 measures with an elongated 4-bar hold on "Ah" and a measure-long repetition of "seeking," and the second equaling 17 measures. The introduction, interlude, and postlude are almost exact repetitions, though some of the instrumentation (notably the bass clarinet and cello) is exchanged.

"Ah! Sun-flower" is scored for voice, clarinet, bass clarinet, violin, viola and cello. The accompaniment creates a conversational atmosphere. All of the instruments are employed throughout the piece in linear interactions with only a few instances of chordal harmonies. Because of the linear nature of the lines and the sounding of small tonal groups,

${ }^{237}$ George Rochberg, Notes by the Composer, quoted in Dixon, 43. 
and given the structure of the row, it is difficult to attach a specific row permutation to the instruments. Often each small set of intervals can be related to multiple versions of the row, making exact identification impossible. There are, however, specific tonal pairs of sevenths and ninths that are common in the accompaniment and which are seen both at important moments in the text and as boundaries of the formal sections: $\mathrm{A}-\mathrm{B} b, \mathrm{E}-\mathrm{E} b$, and C - C\#. ${ }^{238}$ For example, the first two such pairs sound at the beginning of the piece in the cello and violin and make up the first four notes of the original row. Another instance of the motivic-like pairs is in measures 16, where the same instruments follow the soprano's A\#A by sounding $\mathrm{E}-\mathrm{E} b$ and $\mathrm{C}-\mathrm{C} \#$, introducing connecting material between poetic lines. The same interval pairs are heard in a chord in measures 22 and 26, effectively flanking the third line of text.

Interval Pair Examples:
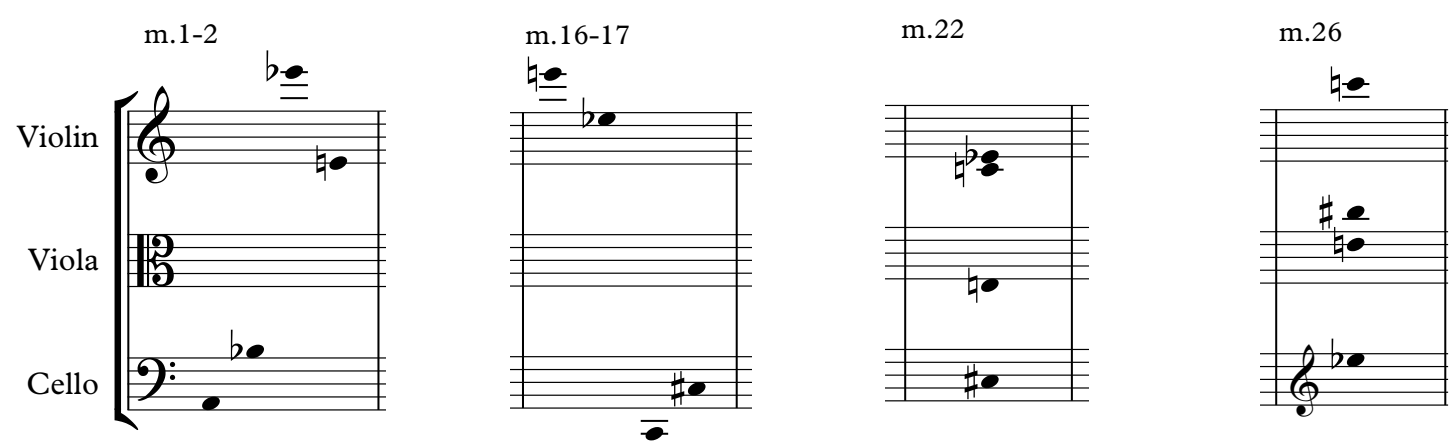

Example 19: Rochberg, “Ah! Sun-flower,” measures 1-2, 16-17, 22, \& 26 Reductions

The first full row is found in the accompaniment introduction and forms the row that is used throughout three of the four pieces in the cycle:

238 June Durkin Johnson, "Analyses of Selected Works for the Soprano Voice Written in the Serial Technique by Living Composers," (PhD Diss., University of Illinois at UrbanaChampaign, 1967), 144. 


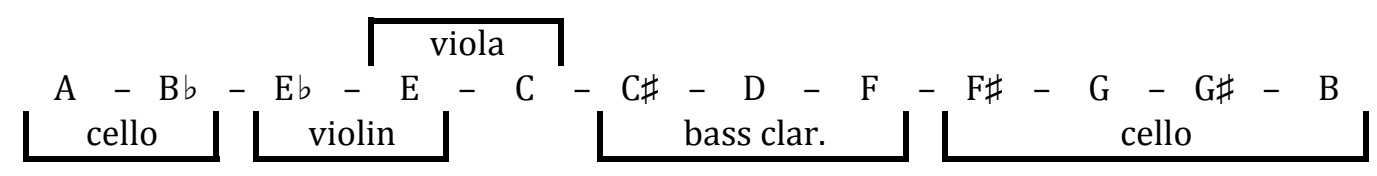

$(9,10,3,4,0,1,2,5,6,7,8,11)$

The first vocal section (consisting of stanza 1, from measures 7-30) consists of complete statements paired with segments ranging from trichords to hexachords primarily taken from the R3 and R0 versions of the row. ${ }^{239}$ Each of the sets is used in distinct ways and serves to either highlight the text or connect with the accompaniment. The first line of text is made up of 7 notes forming a trichord $\mathrm{F}-\mathrm{D}-\mathrm{C} \#$ plus a tetrachord $\mathrm{G}-\mathrm{F} \#-\mathrm{A} \#-\mathrm{A}$ (see Example 20 for the full pitch content of the vocal line). Here, the phrase is harkening back to the instrumental introduction with retrogrades of the bass clarinet line in measures 3-5 for the trichord and the sixteenth-note violin figure in measures 3-4 for the tetrachord. The second line of text echoes the voice figure in measure 15 , but transposes and expands it to form a complete second hexachord from R0. Rochberg pairs a repeat of the word "Seeking," in the third line of text, with a repeat in pitch sets corresponding to the R0 and R6 rows. Specifically, the initial hexachord of D - B - B b - A - A b - F is sounded in measures 22-23, beginning and ending with the repeat of "seeking." This hexachord is then embedded in a complete sounding of an R6 row beginning with the last note of the first "seeking," A b , and continuing to the end of the line on "clime" in measure 27. Here, Rochberg's serial forms take on symbolic meaning; as if the voice is pursuing not only the "sweet golden clime" of the Sun-flower, but also for the completion of the tone row it was "seeking." The first stanza closes with an I6 hexachord, on "where the traveller's journey is done," F\#- F - C - B -

${ }^{239}$ See Figure 3 for the Pitch Content Chart of the vocal line, complete with row forms. 
E b-D, which will become the "nucleus" for the second melodic section. ${ }^{240}$

\section{Vocal Line Pitch Content Chart}

\section{First Stanza}

m. 7-21

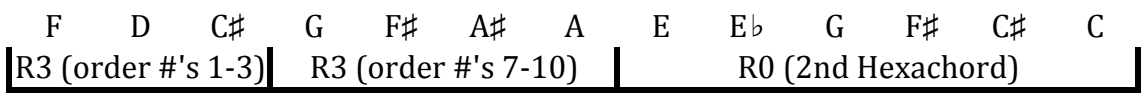

m. 22-26

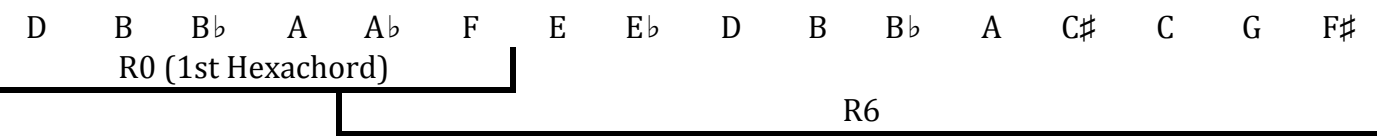

m. 27-30

$\begin{array}{cccc}\text { F\# } \quad \text { F } \quad \text { C } \quad \text { B } & \text { E b } & \text { D } \\ \text { I6 (Ist Hexachord) }\end{array}$

\section{Second Stanza}

m. 39-43

\begin{tabular}{llllllllllllll}
$\mathrm{D} \#$ & $\mathrm{D}$ & $\mathrm{A}$ & $\mathrm{G} \#$ & $\mathrm{C}$ & $\mathrm{B}$ & $\mathrm{B} b$ & $\mathrm{G}$ & $\mathrm{G} b$ & $\mathrm{~F}$ & $\mathrm{E}$ & $\mathrm{C} \#$ \\
\hline
\end{tabular}

m. 44-51

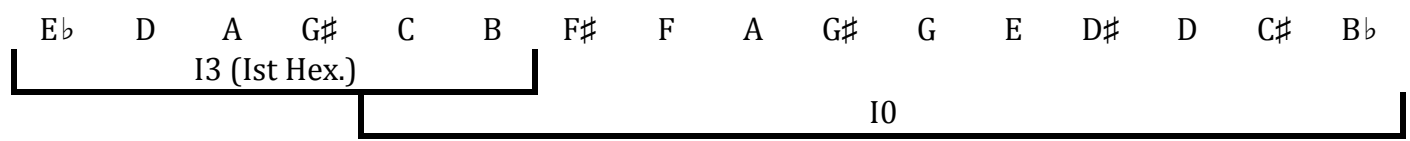

m. 51-56

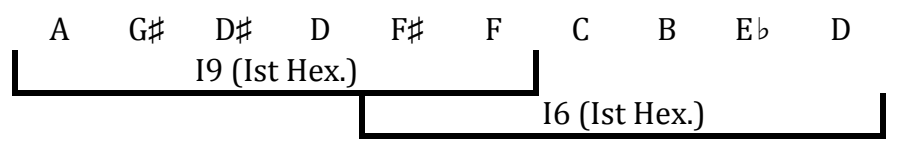

Example 20: Rochberg, “Ah! Sun-flower," Vocal Line Pitch Content Chart

The accompaniment for the first section follows the overall arc of the voice and slowly progresses from short utterances at the start to fuller, more complex, chordal textures. The accompaniment moves up softly through the strings to the woodwinds during the singer's held F5 in measures 7-10. As the length of the singer's phrases increases, so does the instrumental momentum, culminating in measures 22-26 with an almost perfect sounding of a full R9 row in the strings beginning and ending with a $\mathrm{C}-\mathrm{C} \#$ / $\mathrm{E}-\mathrm{E} b$ chord.

${ }^{240}$ June Johnson, 145. 
The final vocal hexachord of this section has the accompaniment dissolving back to the conversational intervals of the beginning, ushering in the interlude between sections.

Two main rhythmic patterns are introduced in the introduction and used consistently in the accompaniment throughout the piece: three consecutive sixteenth-notes begun on an off-beat, an eighth-note tied or slurred to a dotted eighth-note, or variations on either. ${ }^{241}$ Rochberg constantly shifts meters and alters tempi, allowing the basic pulse of the piece to alternate between the eighth- and sixteenth-notes. The instrumental interlude retains these characteristics, though the overall phrase-length is longer than the introduction.

As mentioned above, the second vocal section focuses on transpositions of the inversion of the original row. Following the instrumental interlude, the hexachord sounded at the end of the first stanza is heard again at the start of measure 39, now transposed down a minor $3^{\text {rd }}$ beginning on $\mathrm{D} \# 4$ (first hexachord of I3). The overlapping of row permutations seen in the last lines of the first stanza continues here: a full I3 row is sounded by the voice following the initial transposed hexachord (measures 39-43), then the first hexachord is repeated (using the first two notes of line 7 in the poem) creating a miniature A-B-A form within the phrase. The vocal phrase ends with the last two notes of the previous hexachord becoming the first two notes of another full row (transposed down a minor $3^{\text {rd }}$ again to C4), I0, leading to the climax of the piece on "graves" in measure 50-51. The final vocal phrase is yet another overlap, this time of two transposed hexachords. The trend of a downward minor $3^{\text {rd }}$ movement is displaced by an octave: the voice begins the

${ }^{241}$ June Johnson, 146. 
final phrase in measure 51 on A4 instead of A3 (A - G\#-D\#-D - F\#-F: I9), but then descends a minor $3^{\text {rd }}$ to $\mathrm{F} \#$ for the final hexachord statement (F\#- F - C - B - E b - D: I6).

The climax on "graves" in measure 50 is heralded by not only the rising agitation of the vocal phrase, but also by a progression of flourish-like chords in the accompaniment. The progression of instrumental flourishes begins in measure 46 and repeats a total of three times, each instance adding an instrument and raising in intensity and dynamics. While the dynamics get increasingly louder, the overall pitch class intervals of each chord get smaller and more chromatic (see Example 21). An initial $p p$ chord, which introduces the start of the climactic phrase in measure 45 spans an interval class of 7: D - E b - F\#-G\#-A $[0,1,4,6,7]$. The next chord (measure 47) spans an interval class of 6: D - E b - G - G\# $[0,1,5,6]$ (with an $\mathrm{E}$ and $\mathrm{F}$ present in grace-notes in the clarinet). The last two chords (measure 49 and 51, respectively) span interval classes of 4, the first being F - F\#- G\#-A $[0,1,3,4]$ and the second adding the final chromatic: D\#-E - F - F\#-G $[0,1,2,3,4]$. Following the fermata hold and accompanying caesura, the accompaniment returns to its basics and reprises the introductory material (with a few changes in instrumentation) for the postlude, effectively dying away into $p p p$ sixteenth-note figures.

m. 45

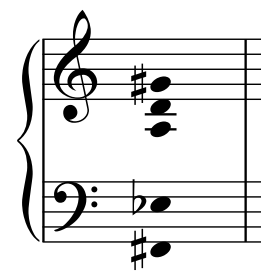

m.47

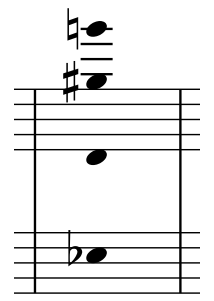

m. 49

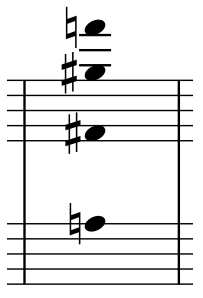

m.51

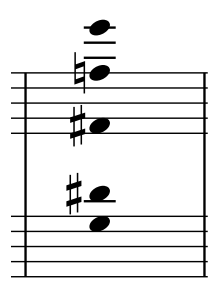

Example 21: Rochberg, "Ah! Sun-flower," Chord spellings

Rochberg sets the "Ah! Sun-flower" text very effectively and employs a number of instances of tone and text painting within the piece. The first occurrence is his almost- 
ironically long introductory sigh, "Ah," in the voice, which spans over three whole measures. While this writing is an obvious embodiment of the act of sighing, there are other, more subtle and ingenious occurrences of text painting in the piece. The repeated, accented notes in the voice on "steps of the sun" in measure 19 depicts the laborious march of time, while the bass clarinet punctuates the march with rests to accent the words. Rochberg's setting of "seeking" in a melismatic and angular line (measure 22) eloquently evokes the image of someone searching, which is emphasized by the "freely" marking above it. Similarly, "golden" in measures 25 and 26, with its chromatic melisma reaching toward the G5 before plummeting down a major 7 th to $\mathrm{F} \# 4$, represents the winding and perhaps ultimately unreachable "climb" that the Sun-flower is "seeking." The next, and most striking, use of melisma is the build-up to the climax in measures 46-51. Here, the image of the youth and virgin rising from the depths of their graves is effectively portrayed by a long melisma on "Arise" with angular, increasingly agitated, leaps. The climax culminates with a two-octave jump on "graves," seemingly contradicting the nature of the word as a place beneath-the-ground. The drama of the climax comes to an abrupt stop and the piece returns to the original tempo with a piano angular phrase for the final lines. Rochberg adds one last moment of emphasis on "sun-flower" in measure 53. The repeated accented notes are reminiscent of the "steps of the sun" in measure 19, but now Rochberg writes the first instances of triplets and quintuplets in the accompaniment. The added complexity of the instruments oddly alienates the steady vocal eighth notes, as if the sunflower is so wrapped up in the "weariness" of its existence that it is blind to the "mystery" and multifaceted beauty of time itself 
As mentioned before, Rochberg's serial structures offer unique avenues for both musical and textual symbolism. "Ah! Sun-flower" is a prime example of how the interconnections and relationships between every aspect of a musical piece can influence one's interpretation of a text. While both Vaughan Williams's and Britten's quite different settings focus on creating moods in order to communicate their personal vision with their listeners, Rochberg's personal interpretation of Blake's poem is embedded in the notes themselves, through their meaningful connections and emblematic organizations.

The analyses of selections from Blake's Songs unearthed both similarities and differences between the approaches and interpretations of the three chosen composers. Each of the above pieces effectively conveys Blake's poetry through unique styling and compositional techniques. In the final chapter, the analyses from Vaughan Williams's Ten Blake Songs, Britten's Songs and Proverbs of William Blake, and Rochberg's Blake Songs will be used to discuss and answer the questions first presented in the introduction. 


\title{
Chapter 6: Conclusions
}

\author{
"But in Eternity the Four Arts: Poetry, Painting, Music, / \\ And Architecture which is Science: are the Four Faces of Man"
}

(William Blake, Milton 27:55-56, E125)

One of the first questions posed in the introduction was the effect of the large timegap between poet and composers, possibly creating a rift in stylistic differences that would hinder the interpretation and overall success of the settings. Upon many readings, hearings, and analyses of Blake's eighteenth century poetry and the accompanying twentieth century music, one can safely say that the opposite cannot be more true. Yes, it is correct that William Blake is considered one of the forerunners of Romantic poetry, and yet the language, imagery, and subject matter of his works fail to fit nicely into any set stylistic period, and certainly not the Romantic era, with its automatic association with overt lyricism, love in all forms, and the beauty of nature. The social, moral, and philosophical subjects of Blake's works, all of which are exterior to these Romantic concerns, are actually quite suited to the artistic and musical views of modern times, where an importance of selfexpression and social commentary often take precedence over pure entertainment. In speaking specifically about Britten, Barbara Meister goes so far as to suggest that "settings by composers of the generation which followed Blake - Chopin, Schumann, Mendelssohn, or Liszt, for example — would have suited this poet's [Blake's] angular, angry, provocative, didactic work far less well."242

All three composers approach Blake's work through modern musical idioms, albeit in three distinct and unique ways, each highlighting different aspects of their personal interpretation and understanding of the poetry. Vaughan Williams's writing could be seen

${ }^{242}$ Meister, "Interaction," 252. 
as most resembling Blake's original style. The modern folk characteristics keep the overall harmonic and modal structures of the pieces simple, allowing the melodies and texts to be of prime importance. The subtle complexities and symbolic gestures, which are so concentrated in the poems, are captured in motivic and rhythmic alterations within the framework of a single stylistic entity. Much like Blake's Songs, where the poetry is placed within a single visual image, Vaughan Williams creates a particular mood or structure for each piece and then works within that mold to enhance and communicate the text. The overall idea of a melody-centric composition for the Songs is also Blakean in nature. We know that Blake performed his Songs to simple accompaniment on a number of occasions, though no record of any compositions exist today, and that he favored the idea of "line" in art, poetry, and music. There is a whole body of criticism that explores Blake's central stylistic aesthetic of the "line" in opposition to the textural concept of harmony. Examples can be cited pertaining to the three major arts - poetry, painting, and music. The importance of line in painting for Blake is quite obvious, since his occupation as an engraver favors distinct lines and forms versus the blurry, coloristic effects of other artists of the time (see Blake's quote regarding his own work on page 50). In music, he rejected conventional harmony because he saw it as "rationalistic and geometrical" (an example is Urizen's creation of proportioned "antimusic" in The Four Zoas) and, instead, offered a "True Harmony," which focused on a synthesis of melody and harmony versus the hierarchy of one over another. ${ }^{243}$ While this discussion of Blake's particular views on harmony is not essential to this particular study, it does affirm the fact that the "line" (and,

${ }^{243}$ Fairchild, Holy Song, 90. 
in turn, melody) is a central concept of the Blakean style. ${ }^{244}$ This idea of a melody-centric Blakean aesthetic paired with the fact that Vaughan Williams wrote nine of the songs in four days, with the remaining "The Lamb" coming to him in a dream, is nothing short of prophetic in its genesis - a mystical characteristic that surely would have pleased Blake himself.

If one focuses on the complexities of Blake both as a person and an artist, it is Britten's work that stands out as characteristically Blakean. Britten's unique blending of tonal, modal, and twelve-tone techniques into perfectly executed musical interpretations emphasizes the many layers of meaning in Blake's poems. Britten's Songs and Proverbs could be viewed as something attaining Blake's sought-after "True Harmony" mentioned above, a complete synthesis between melody, harmony, and text. Britten, known for his high level of prosody, did not shy away from Blake's seemingly simplistic text, setting the poetry syllabically and reserving any melismatic writing for distinct interpretive purposes. This enabled Britten to emphasize the text while also maintaining the essential foundation of the poems. Britten used repetition of text far more than either of the other two composers, suggesting a focus on personal interpretation versus direct, straightforward settings. Notable repetitions, like those in "A Poison Tree" and "The Fly," represent either a chosen unifying theme or a further examination of a symbolic moment (as in the growing wrath and frenzied dance, respectively). Britten's music for Songs and Proverbs may be less "singable" than Vaughan Williams's settings and is surely more dense and complex, but that can also be seen as Blakean in its own way. The fact that Britten's music is difficult, "craggy," unsentimental, mostly pessimistic and quite demanding of both the musicians and

${ }^{244}$ On Blake's "line-centric" aesthetic, see B.H. Fairchild's Such Holy Song, pages 89-92. 
listeners makes it in some ways analogous to the poetry and art of Blake, "whose so-called 'Prophetic Books' are still challenging scholars after almost two centuries of study."245 The amount of thought and obvious effort that exudes from Britten's settings mirror Blake's artistic determinations and demonstrates a shared seriousness of purpose and mastery of their arts.

Carrying the theme of a Blakean nature, Rochberg, too, demonstrates an embodiment of Blake's personal aesthetics, creating meaningful and authentic art that is quite distinct from either Vaughan Williams or Britten in its Blakean features. Rochberg's serial settings are so interconnected that they harken to Blake's belief of the simultaneity of all occurrences and the importance and divinity of all things. This unity in Rochberg's cycle is achieved through concise and economical motivic combinations paired with a unifying row that is used through almost all of the movements. The small tonal groups in the accompaniment (often based on the intervals of a seventh or ninth), which are repeated, transposed, and altered constantly throughout the cycle, exist so that every note, if one so chose, could be related to every other note in some way, whether through a row transformation, intervallic relationship, or parallel rhythmic pattern. The vocal line, often angular and employing frequent large leaps, acts as yet another unifying element with often complete, overlapping, or distinct segmentations of rows. Unity does not only exist within each piece, but throughout the entire cycle as well. In addition to the obvious use of the same row for three of four pieces, certain motives and combinations of tones (such as the $\mathrm{C}$ - C\#, E - E b combination often appearing at cadential moments) occur in all of the pieces.

245 Meister, "Interaction," 253. 
And while the instrumentation for each piece is different, the strings act as a constant, with all three instruments (violin, viola, cello) present in each song.

While the serial structures are indeed exemplary examples of Rochberg's ability to captivatingly unify a cycle, it is also the case that this is largely guaranteed by Schoenberg's rules for serial composition. It is, rather, the care and expression with which he sets Blake's text that is the most impressive aspect of this work. Through all the structural complexities (adaptations of melody and row, constant meter, tempi, and rhythmic changes, complicated accompanimental conversations), Blake's text remains the most important factor. Rochberg's ability to "set the music to the words in such a way that their meaning is immediately reinforced" is evident in almost every phrase. ${ }^{246}$ His symbolic use of sprechstimme and his text-painting bring the poetry to life within what Rochberg himself would later consider the tight framework of the twelve-tone method, adding a layer of textual connection to the already existing tonal relationships. This idea that multiple relationships (between text and melody, melody and accompaniment, instrument and instrument, etc.) are occurring simultaneously within any given moment of musical time directly relates to Blake's understanding of simultaneous personal states within a single mind. It is the philosophical beliefs of Blake, his focus on inter-connectivity and the importance of instinctual interactions, that come so clearly to the foreground in the Rochberg works, achieving thereby a complex cohesiveness worthy of Blake's multidimensional Songs.

${ }^{246}$ June Johnson, “Analysis of Selected Works," 165. 
The second question posed in the introduction concerned the arrangement of the pieces within each cycle and how, if at all, it altered or affected the intent of the original volume. Again, each composer approaches this idea in a different way. Vaughan Williams's Ten Blake Songs was commissioned for a film honoring the bicentennial of Blake's birth. From Ursula Vaughan Williams's account of the commission (see page 69), it can be assumed that he did not have much say in exactly which poems to set: it was his job to create music, not necessarily form a cohesive cycle meant for anything but the film. In this regard, the arrangement of the cycle is of less importance than the individual pieces. Naturally, Vaughan Williams arranges the settings in a pleasing musical arc (he does not place all the a cappella songs side-by-side, for example), but one does not get a strong sense of rigid programming, and it would be easy to excerpt selections for a shortened performance of the cycle. Certainly any subtle progression that Blake put in his original arrangement of the poems is lost in the Vaughan Williams cycle. One is left to enjoy and interpret each individual piece as it is introduced through the course of the cycle.

The opposite is true for Britten's Songs and Proverbs. Not only is the cycle more or less continuous, with attaccas marked at the end of almost every section, but the arrangement and pairing of the proverbs and poems are obviously deliberate and essential to the overall arc of the piece. We know that Peter Pears was instrumental in creating the "story-line" for the Songs and Proverbs, picking proverbs that act as connecting material between each poem from Songs of Experience. The program seems to progress through Blake's principal philosophies, with each moralizing proverb representing a certain idea or instruction and each poem exploring that idea. Britten and Pears take the listener on a Blakean journey that explores "social reform, personal integrity, the mystery and terror of 
creation, the sanctity of all life, the tragedy of sexual repression and the presence of eternity in every moment," a remarkably broad assortment of the poet's principal concerns. ${ }^{247}$ There has been a good deal of criticism regarding the connections and arrangement of Blake's Songs, and yet, apart from a few obvious parallels (like "The Lamb" and “The Tyger," for example), we can still only surmise Blake's exact intentions. Britten's cycle, however, puts a purpose and connection, by way of the added proverbs, into the program. While Britten's arrangement is not the same as the original ordered volume, the deliberateness of the order is important and it cannot be altered. Britten provides the listener with a personal story that unites Blakean ideas and effectively communicates them through musical expression, revealing new connections between and highlighting different meanings within the texts.

Rochberg's Blake Songs consists of only four Blake poems, but the intention in programming is clear, and is more similar to Britten than Vaughan Williams. It was mentioned earlier that Rochberg begins his cycle with "Ah! Sun-flower," a poem that is near the end in both the Vaughan Williams and Britten cycles. This poem, with its heavy philosophical questioning of time, serves as a poignant introduction to the rest of the cycle. Again, the arrangement of the poems does not match the original, though it is closer than the other two cycles. The three poems following "Ah! Sun-flower," "Nurse's Song," "The Fly," and "The Sick Rose," are grouped together in the original volume, though not in this particular order. "Ah! Sun-flower" is taken from further along in the work, yet is placed at the beginning, symbolically shading the other poems with a veil of the "world-weariness of

247 Meister, “Interaction," 258. 
human existence." ${ }^{48}$ Like the Britten cycle, Rochberg puts his own interpretive meaning into the placement of the poems, and while it may not completely match Blake's intentions, the arrangement serves an interpretive purpose. In short, all three composers arranged the Songs differently, none keeping to the original construction, but some organizing the poems more purposefully than others. As discussed earlier, Blake's reasoning for placing the poems in any one order is not known, and the question of whether or not the three composers' cycles altered the original intentions opens up a huge topic, that of composer interpretation. In brief, the question is what is the exact purpose of setting a poem to music at all? The next three questions asked in the introduction will be discussed together, with the aim of shedding light on this question of musical purpose.

The following three questions can be grouped under the umbrella term "interpretation:" How do the interpretations differ between composers? Is the music a simple musical translation of the poetry or does it attempt to convey a unique interpretation by the composer? And how, if at all, does the music portray not just the poem but also the visual image associated with the poetry? Interpretation itself is a muddy and elusive term and one that, especially for artists, is rooted in communication. Each artistic avenue communicates a personal interpretation through different means: painters use brushstrokes, writers use words, and composers use notes. Over the course of the analyses of the selected works, no glaring oppositions of meaning or interpretation were uncovered between the composers; in fact, though the inherent musical language of each composer is quite different, more similarities were found than originally anticipated. Both Vaughan Williams and Britten set "London" within the realm of personal reflection,

${ }^{248}$ George Rochberg, Notes by the Composer, quoted in Dixon, 43. 
matching the melancholy of the poem (and poet) and expressing the apparent moral divide of the city. Britten's music paints a more agitated and restless speaker, with wandering polytonal accompaniment and often wail-like vocal lines. Vaughan Williams chooses to depict a wearier traveler who tells his story through sorrowful solo phrases. Neither setting evokes the visual image of "London," instead concentrating on the intensely poignant language that describes the city. Like Blake, both Vaughan Williams and Britten had strong ties to the city of London, so it is not surprising that the two settings would embody an intimate and personal response to Blake's words.

The next poem, "A Poison Tree," demonstrates a more interpretive side of the two composers of "London." Both composers chose to concentrate on the constant growth of the speaker's wrath. Vaughan Williams represents the "wrath" through the oboe line, employing a D pedal that is sounded at each step in the progression of forming the poisoned apple in the tree. Britten uses recurring motives to symbolize the speaker's wrath and the growing tree. The first motive ("wrath") is symbolic in nature as the accented quarter-notes trudge along in a fugue-like stretto throughout the piece, while the "growth" motive is more descriptive, rising up in triadic motion as if a budding tree. The symbolic elements embedded in the two settings certainly bring to mind the visual image accompanying "A Poison Tree," resulting in a satisfying fusion between all three artistic mediums.

Britten and Rochberg's interpretations of "The Fly" are the most dissimilar of the group. Britten's “The Fly" is quite reactionary to the poetry and offers some of the most descriptive compositional figures in the cycle, most notably in the natural characteristics of the fly written into the fluttering accompaniment. Britten portrays the speaker as mostly 
one-sided, highlighting his thoughtless, carefree nature most notably in an elongated sequence on "For I dance...," and touching only briefly on the philosophical moment in stanza 4 ("If thought is life...") without ever really leaving the flippancy of previous stanzas. Rochberg offers a darker, more philosophical, rendering of the speaker. While Rochberg's setting begins with a similar focus on depicting insect characteristics (with buzzing accompanimental figures and the possible symbolism in the sprechstimme), the dance section abruptly shifts from a danse macabre waltz to a deep, satirical, realization of the inescapable weight of life and death. This seriousness shadows the rest of the piece and gives Rochberg's setting a level of esotericism that is not present in Britten's rendition. Not surprisingly, neither composer attempts to illustrate or evoke the visual image of "The Fly." As discussed earlier, the accompanying summer scene results in more questions than answers for the poem, and engaging with this would require the addition of an entire other layer of ambiguity onto an already difficult text.

Vaughan Williams and Britten approach the next two poems, with very different subjects, in remarkably similar ways. The music for "The Lamb" and "The Tyger" is both illustrative of the text and interpretative in the setting. Vaughan Williams depicts the image of a lamb through a carefree independent oboe line that seems to play about the voice as it sings its folk-driven melodies. While there are no glaring intentions to write the visual image into the music, the overall contentment expressed in the piece can be easily related to the charming scene illustrated by Blake. The choice to emphasize the natural subjects in the poem (the speaker and the lamb), rather than the religious themes, makes the setting somehow more relatable and effective. Britten's “The Tyger” employs a similar illustrative organization. The piano plays the part of either the stealthy Tyger or, in the dramatic $5^{\text {th }}$ 
stanza ("When the stars threw down their spears..."), of the awestruck stars raining down their tears, while the voice rides above and intertwines, interpreting the text through syncopated, breathless terror. The accompanying visual image is not as easily conjured in this case versus “The Lamb," though Britten's decision to portray the titular beast as elusive and stealthy is much more relatable to the oddly pictured tiger than a thundering, primal musical representation would be.

The final analysis section, in a broad sense, can be seen as exploring musical embodiments of the composers' relationships to both their compositions and Blake's poetic works. "Ah! Sun-flower," with its esoteric musings on time and our connection to the present world, offers a chance for the composers to express their own ideals through Blake's carefully constructed lines. The circumstances of Ten Blake Songs having been commissioned for an outside film, paired with Ursula Vaughan Williams's biographical account, suggests that Vaughan Williams was not as personally invested in the prospect of setting Blake's well-known poetry. Of course this must be balanced with our knowledge that the pieces flew from Vaughan Williams's mind in a whirlwind of creativity, suggesting he had a far better understanding of Blake's works than might first be presumed. "Ah! Sunflower" is representative of this balance between pure declamation and deep contemplation. The exotic triplet motive that permeates the setting and the parallels between the voice and oboe lines distinguishes "Ah! Sun-flower" from the rest of the cycle. The piece resonates with a sureness of conviction of the fruitlessness of the sunflower's hope for a utopian eternity, almost chastising the subject in the hopes of convincing it to find pleasure in the here and now. This differs from other pieces in the cycle, where the abundance of motivic writing is meant to symbolize or describe something concrete in the 
text. Yes, there are moments of text-painting and the overall compositional structures are similar, but the effect of this piece is different. Here, Vaughan Williams shows a distinct attitude towards Blake's poem and reveals his own views on how one should spend their brief time on Earth.

Britten's "Ah! Sun-flower," as mentioned earlier, offers a more empathetic interpretation of the poem. The lyrical vocal line that soars over the descriptive piano writing acts as an affirmation of the sunflower's hope. It is as if Britten is saying that it is perhaps, appropriate, even if unreasonable, to wish for something better, however futile that wish may be. This interpretation takes on new meaning united with a consideration of the genesis of the cycle. The death of Fischer-Dieskau's daughter had to be a source of inexplicable grief; a source of darkness and seriousness that permeates much of the music in the cycle. The hope of the sunflower for a place beyond Earth where all troubles disappear is a very appealing thought when experiencing such pain or loss of life. Britten's setting of "Ah! Sun-flower" recognizes this feeling and, through the course of the piece, tries to bring the subject back to Earth and to the importance of the present.

Like those of the other two composers, Rochberg's setting of "Ah! Sun-flower" is representative of his understanding of, and affinity for, Blake's poetry. Far more than the other two composers, Rochberg delves into the Blakean concepts of interconnectivity and the importance of a simultaneous existence through the combination of complex serial structures and symbolic text-painting. Rochberg's setting is also the only one of the three that could be said to offer any connection to the visual image for "Ah! Sun-flower." The accompanying plate places "Ah! Sun-flower" between two other poems with flower 
subjects. ${ }^{249}$ The correlation of the structural elements of "Ah! Sun-flower" and the other pieces in the cycle, the use of the same row, motivic and intervallic unity, and similarities in form, could be seen as a direct parallel to the symbolic connections between the poems on the plate. Whether or not that was a specific intention, the parallel of thought between Rochberg and Blake regarding "Ah! Sun-flower" cannot be overlooked.

The overall goal of an art song is to not just translate words into music, but to create a new entity "capable of expressing the content of the poetry as it is filtered through the emotions, intelligence, and aesthetic preferences of the composer."250 The three composers chosen for this study represent different spectrums of the musical language, but their resulting compositions equally achieve a synthesis with Blake's well-known and often oversimplified verses. Each setting went beyond merely translating the content of the poetry. Instead, the music intensified and clarified Blake's complicated messages, and revealed in "harmony, melody and rhythm the images partly concealed, partly revealed, by the words themselves." ${ }^{251}$ Through the analysis of the various poems and compositions, this document has tried to clarify the differing ways in which the musical settings enhance, express, and accentuate the poetry, perhaps offering new appreciations for the many different styles of twentieth-century composition and celebrating the abilities of dedicated artists who communicate in such satisfyingly intelligent and nuanced means.

II.

The final questions posed in the introduction deal with the role of the performer and their unique part in the art song equation. While it would not be appropriate here to delve

249 The connections between the poems on the plate were briefly discussed on page 169170.

250 Meister, "Interaction," 263.

251 Ibid., 261. 
deeply into the realm of "what is appropriate performance etiquette," which by nature is highly subjective and personal, nor would it be appropriate to launch into a drawn-out essay on "how to prepare an art song," a brief discussion on the specific case of well-known poetry is warranted. When it comes to the poetry of an art song, there seems to be two categories for a performer - the known and the unknown. One is either already familiar with the poet, and either the specific work of the piece or other works representing the poet's style, or both poem and poet are new. In the latter case, it is understandable that the performer is introduced to the new poet's style through the veil of the composer's music, essentially creating a personal reaction to the poetry by way of the composer's interpretation. This is by no means a wrong way to go about things, especially for young singers who are just starting to build their repertoire of known poets and composers. For more mature performers, their knowledge base of poetry may be a bit more substantial, and the chance of encountering poetry (especially in one's native language) that has previously been studied and enjoyed is more common. The task becomes melding one's personal understanding of the poet and poetry with the composer's proposed interpretation. How much of your own interpretation do you then bring to the performance? And, going further, is it possible to honor everyone's intentions (poet, composer, teacher, etc.) and still be one's self in a performance?

The answers lie in the infinite number of choices one must make in the preparation of and during a single performance. Very often, singers hear the phrase, "be a channel" - a channel for the music, a channel for the composer, a self-less channel to the audience. While yes, it is true that once one steps out onto the stage and begins to communicate a piece of art to a waiting audience, selfish thoughts and self-serving techniques have no 
place. However, using that phrase as a blanket statement can be misleading. If one does nothing more than regurgitate exactly what is on the page, the performance would be astoundingly correct, but may lack a certain personality that is so often praised in the most famous singers. It is the added personal interpretation, the deep knowledge of music and poetry, achieved only through study and preparation, that enables the performer to truly "channel" the music. In this regard, a previous knowledge of the poetry of a given composition is extremely useful and adds another layer of understanding and unique perspective to a performance.

In a way, the performance of an art song is quite Blakean in nature. The simultaneous occurrence of thoughts, words, music, and sound in order to communicate within a split-second of time parallels many of the beliefs discussed in this study. The existence of such a connection between singer, pianist, and audience emphasizes the instinctual nature of music and words. But, like Blake's work, in order to achieve such a connection, the performer must be dedicatedly precise and multi-faceted in their preparation - every note, expression, vocal nuance, gesture, rhythm, etc., has purpose and is practiced. Once this preparation has been instilled in the performers, the performance takes on a new life, one of spontaneity and emotion, as Francis Poulenc, speaking of his song cycle La Fraîcheur et le feu, comments: "The technical side must be perfected with cold precision, then, sure of oneself, one should forget everything and give an impression of improvising, listening only to one's instinct."252 The result is a truly personal performance, where preparation gives way to instinct and each part of the art song performance is given equal importance: poet, composer, singer, pianist, and audience.

252 Pierre Bernac, Francis Poulenc: The Man and His Songs, trans. Winifred Radford (New York: W.W. Norton, 1997), 49. 
Music and poetry are sister arts, each shaping the flow of time through controllable and purposeful elements. An art song combines the two into a single organism, where the two arts no longer run in parallel, but exist simultaneously. William Blake believed in simultaneous existences and intuitive responses, which manifests in his world through the combination of arts. His Songs of Innocence and of Experience creates a composite art form of poetry, engraving, painting, and music. The musical elements embedded in the poetry are intuitive; even without set notes and rhythms, the reader feels the music entwined with the words. It is as if the musical rhythms underlie "the relative simplicity and complexity of the 'two contrary states of the human soul': innocence and experience.".253 It is this organic complexity that permeates the settings of Vaughan Williams, Britten, and Rochberg and creates complicated yet instinctual responses in readers and performers. The music examined in this study succeeds in offering diverse artistic possibilities for Blake's poetry. Each unique style uncovers different expressions and interpretations within the words, and each setting is a tribute to the transcendent power of art and imagination - a belief that is essential to Blake's doctrine and one that has had an impact upon generations of artists around the globe.

${ }^{253}$ Fairchild, Holy Song, 90. 


\section{Bibliography}

Banks, Paul, ed. The Making of Peter Grimes: Essays and Studies. Woodbridge, UK: Boydell, 1996.

Beer, John. William Blake: A Literary Life. New York: Palgrave Macmillan, 2005.

Bentley, G.E. Jr. The Stranger from Paradise. New Haven: Yale University Press, 2001.

Bernac, Pierre. Francis Poulenc: The Man and His Songs. Trans. Winifred Radford. New York: W.W. Norton, 1997.

Blake, William. The Complete Poetry and Prose of William Blake. Ed. David V. Erdman. Berkeley and Los Angeles: University of California Press, 2008.

- - Songs of Innocence and of Experience. Ed. Andrew Lincoln. Princeton: Princeton University Press, 1991.

Blyth, Alan and Heather Wiebe. "Pears, Sir Peter." Grove Music Online. Oxford Music Online. Oxford University Press, accessed November 16, 2016. http://www.oxfordmusiconline.com/subscriber/article/grove/music/21147.

Bogen, James and Fred Goss, ed. Sparks of Fire: Blake in a New Age. Richmond, California: North Atlantic, 1982.

Brett, Philip, Heather Wiebe, Jennifer Doctor, Judith LeGrove, and Paul Banks. "Britten, Benjamin." Grove Music Online. Oxford Music Online. Oxford University Press, accessed November 14, 2016. http://www.oxfordmusiconline.com/subscriber/article/grove/music/46435.

Britten, Benjamin. “Conversation with Benjamin Britten.” Tempo 6 (February, 1944): 4-5.

"Carlsbad Decrees." The Columbia Encyclopedia, 6th ed. Encyclopedia.com. Accessed October 16, 2016. http://www.encyclopedia.com/reference/encyclopedias-almanacstranscripts-and-maps/carlsbad-decrees.

Chew, Geoffrey, Thomas J. Mathiesen, Thomas B. Payne, and David Fallows. "Song." Grove Music Online. Oxford Music Online. Oxford University Press, accessed January 2, 2017. http://www.oxfordmusiconline.com/subscriber/article/grove/music/50647.

Clark, Steve, Tristanne Connolly and Jason Whittaker, ed. Blake 2.0: William Blake in Twentieth-Century Art, Music and Culture. New York: Palgrave Macmillan, 2012.

Clarkson, Austin and Steven Johnson. "Rochberg, George." Grove Music Online. Oxford Music Online. Oxford University Press, accessed November 16, 2016. http://www.oxfordmusiconline.com/subscriber/article/grove/music/23617. 
Cone, Edward T. The Composer's Voice. Berkeley and Los Angeles: University of California Press, 1974.

- - - "Music: A View from Delft." In Music: A View from Delft, ed. Robert P. Morgan, 13-27. Chicago: University of Chicago Press, 1989.

- - - "Words into Music: The Composer's Approach to the Text." In Music: A View from Delft, ed. Robert P. Morgan, 115-123. Chicago: University of Chicago Press, 1989.

Davies, Keri. "Blake Set to Music." In Blake 2.0: William Blake in Twentieth-Century Art, Music and Culture, ed. Steve Clark, Tristanne Connolly, and Jason Whittaker, 189208. New York: Palgrave Macmillan, 2012.

Dickstein, Morris. "Counterculture." In Encyclopedia of American Studies, ed. Simon Bronner. Maryland: Johns Hopkins University Press, accessed November 4, 2016. http://www.libproxy.wvu.edu/login?url=http://search.credoreference.com/content/en try/jhueas/counterculture/0.

Dixon, Joan DeVee. George Rochberg: A Bio-bibliographic Guide to His Life and Works. Stuyvesant, New York: Pendragon, 1992.

Fairchild, B.H. Such Holy Song: Music as Idea, Form, and Image in the Poetry of William Blake. Kent, Ohio: Kent State University Press, 1980.

Fischer-Dieskau, Dietrich. The Fischer-Dieskau Book of Lieder. Chosen and introduced by Dietrich Fischer-Dieskau. English translations by George Bird and Richard Stokes. New York: Limelight Editions, 1995.

Fitch, Donald. Blake Set to Music: A Bibliography of Musical Settings of the Poems and Prose of William Blake. Berkeley and Los Angeles: University of California Press, 1990.

Gillham, D.G. Blake's Contrary States: The "Songs of Innocence and of Experience" as Dramatic Poems. London: Cambridge University Press, 1966.

Goode, Mike. "Blakespotting.” P M L A 121:3 (2006): 769-86.

Grant, John E. “Interpreting Blake's 'The Fly'.” In Blake: A Collection of Critical Essays, ed. Northrop Frye, 32-55. Englewood Cliffs, New Jersey: Prentice-Hall, 1966.

Johnson, Graham. Britten, Voice and Piano: Lectures on the Vocal Music of Benjamin Britten. Ed. George Odam. Aldershot, Hampshire: Ashgate, 2003.

———. "Voice and Piano." In The Britten Companion, ed. Christopher Palmer, 286-307. London: Faber and Faber, 1984. 
Johnson, June Durkin. "Analyses of Selected Works for the Soprano Voice Written in the Serial Technique by Living Composers." PhD Diss., University of Illinois at UrbanaChampaign, 1967.

Kennedy, Michael. The Works of Ralph Vaughan Williams. London: Oxford University Press, 1964.

Kimball, Carol. Art Song: Linking Poetry and Music. Milwaukee, Wisconsin: Hal Leonard, 2013.

——_. Song: A Guide to Style and Literature. Redmond, Washington: Pst..., 1996.

Kramer, Lawrence. Music and Poetry: The Nineteenth Century and After. Berkeley and Los Angeles: University of California Press, 1984.

McFarland, Ian A. "Enthusiasm." In Cambridge Dictionary of Christian Theology, ed. Karen Kilby et al. Cambridge: Cambridge University Press, 2011, accessed October 29, 2016.

http://www.libproxy.wvu.edu/login?url=http://search.credoreference.com/content/en try/cupdct/enthusiasm/0.

Meister, Barbara. "The Interaction of Music and Poetry: A Study of the Poems of Paul Verlaine as Set to Music by Claude Debussy and of the Song Cycle 'Songs and Proverbs of William Blake' by Benjamin Britten (France; England)." PhD Diss., City University of New York, 1987.

Ostriker, Alicia. "Metrics: Patterns and Variations." In Twentieth Century Interpretations of Songs of Innocence and of Experience: A Collection of Critical Essays, ed. Morton D. Paley, 10-29. Englewood Cliffs, New Jersey: Prentice Hall, 1969.

Ottaway, Hugh and Alain Frogle. "Vaughan Williams, Ralph." Grove Music Online. Oxford Music Online. Oxford University Press, accessed April 18, 2017. http://www.oxfordmusiconline.com/subscriber/article/grove/music/42507.

Otto, Peter. “'Rouze up 0 Young Men of the New Age!': William Blake, Theodore Roszak, and the Counter Culture of the 1960s-1970s." In Blake 2.0: William Blake in TwentiethCentury Art, Music and Culture, ed. Steve Clark, Tristanne Connolly, and Jason Whittaker, 27-40. New York: Palgrave Macmillan, 2012.

Paley, Morton D., ed. Twentieth-Century Interpretations of Songs of Innocence and of Experience: A Collection of Critical Essays. Englewood Cliffs, New Jersey: Prentice Hall, 1969.

Pinsky, Robert. The Sounds of Poetry: A Brief Guide. New York: Farrar, Straus and Giroux, 1999. 
Ringer, Alexander L. "The Music of George Rochberg." Musical Quarterly Vol. 52, No. 4 (Oct., 1966): 409-430.

Roberts, Jonathan. William Blake's Poetry: A Reader's Guide. London: Continuum, 2007.

Rochberg, George. The Aesthetics of Survival: A Composer's View of Twentieth-Century Music. Ann Arbor: University of Michigan Press, 2010. Accessed November 16, 2016. ProQuest ebrary.

Roszak, Theodore. The Making of a Counter Culture: Reflections on the Technocratic Society and its Youthful Opposition. Rev. ed. Berkeley and Los Angeles: University of California Press, 1995.

Schoenberg, Arnold. "Opinion or Insight." in Style and Idea: Selected Writings of Arnold Schoenberg, ed. Leonard Stein, trans. Leo Blake, 258-263. Berkeley and Los Angeles: University of California Press, 1975.

The Proceedings of the Old Bailey: London's Central Criminal Court, 1674 to 1913. "Currency, Coinage, and the Cost of Living." Accessed November 1, 2016. https://www.oldbaileyonline.org/static/Coinage.jsp.

Vaughan Williams, Ralph. Vaughan Williams on Music. Ed. David Manning. New York: Oxford University Press, 2008. Accessed November 14, 2016. ProQuest ebrary.

Vaughan Williams, Ursula. R.V.W.: A Biography of Ralph Vaughan Williams. London: Oxford University Press, 1964.

Wierzbicki, James. "Reflections on Rochberg and 'Postmodernism'." Perspectives of New Music Vol. 45, No. 2 (Summer, 2007): 108-132.

\section{SCORES}

Britten, Benjamin. Songs and Proverbs of William Blake: For Baritone and Piano, Op. 74. New York: G. Schirmer, 1965.

Rochberg, George. Blake Songs: For Soprano and Chamber Ensemble. New York: Leeds Music Corp., 1963.

Vaughan Williams, Ralph. Ten Blake Songs: For Voice and Oboe. London: Oxford University Press, 1958. 


\section{Appendix A}

\section{Chronology of Important Dates}

* from Morton Paley's Twentieth Century Interpretations of Songs of Innocence and of Experience: A Collection of Critical Essays, pg 111-112.

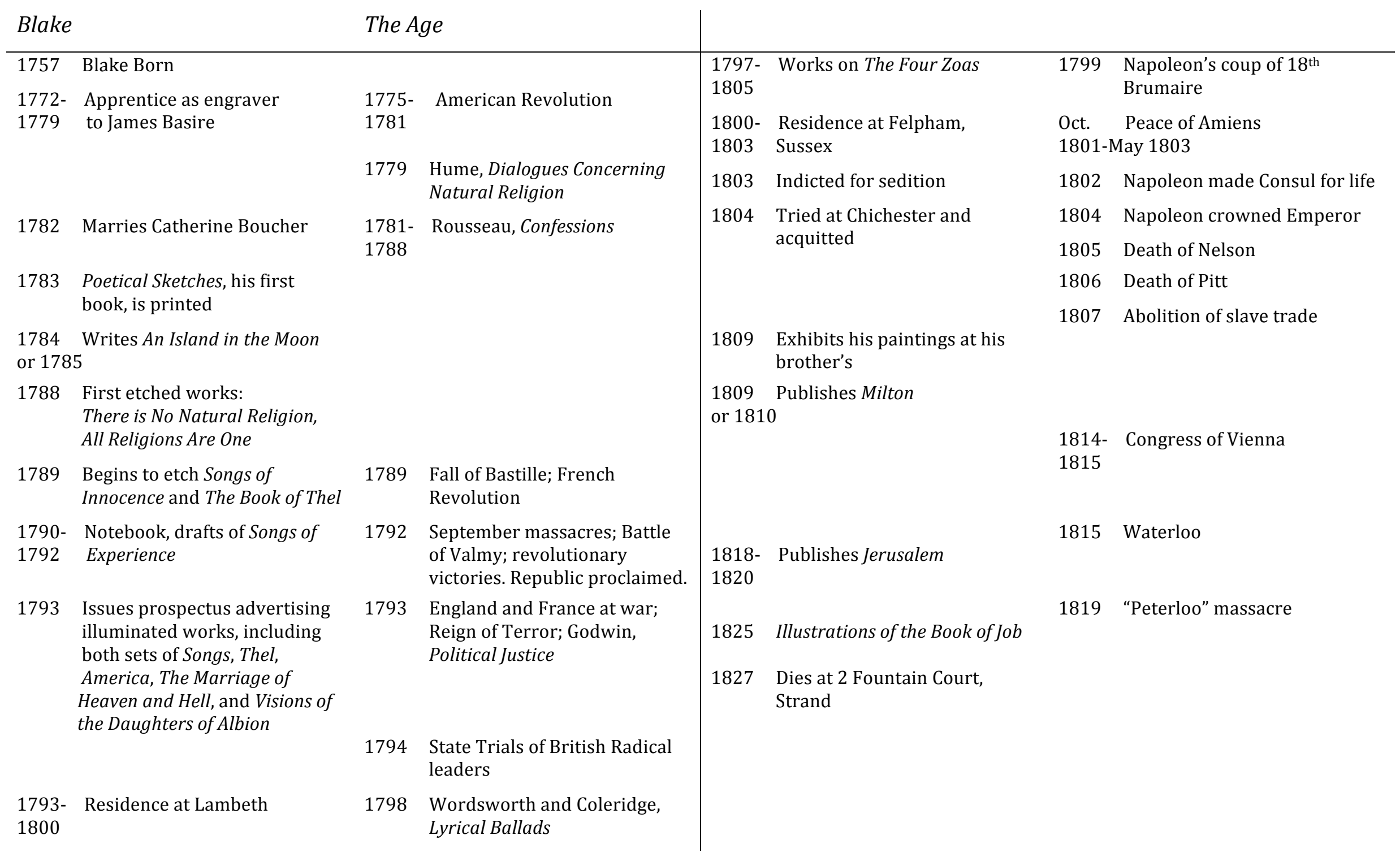




\section{Appendix B}

\section{Extra Plates and Images}

* from The William Blake Archive, www.blakearchive.org

America: A Prophecy, plate 5

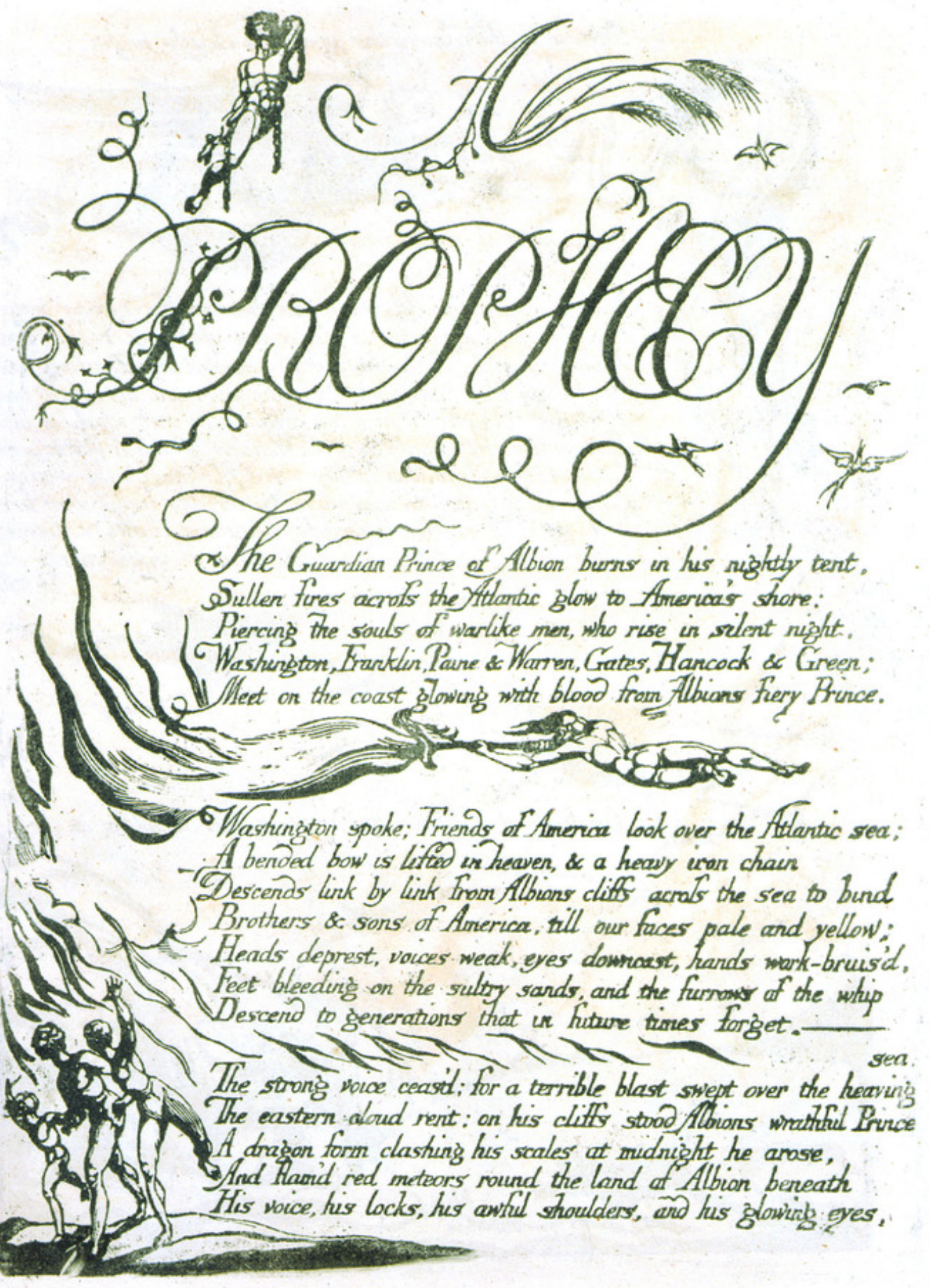


The Marriage of Heaven and Hell, plate 4

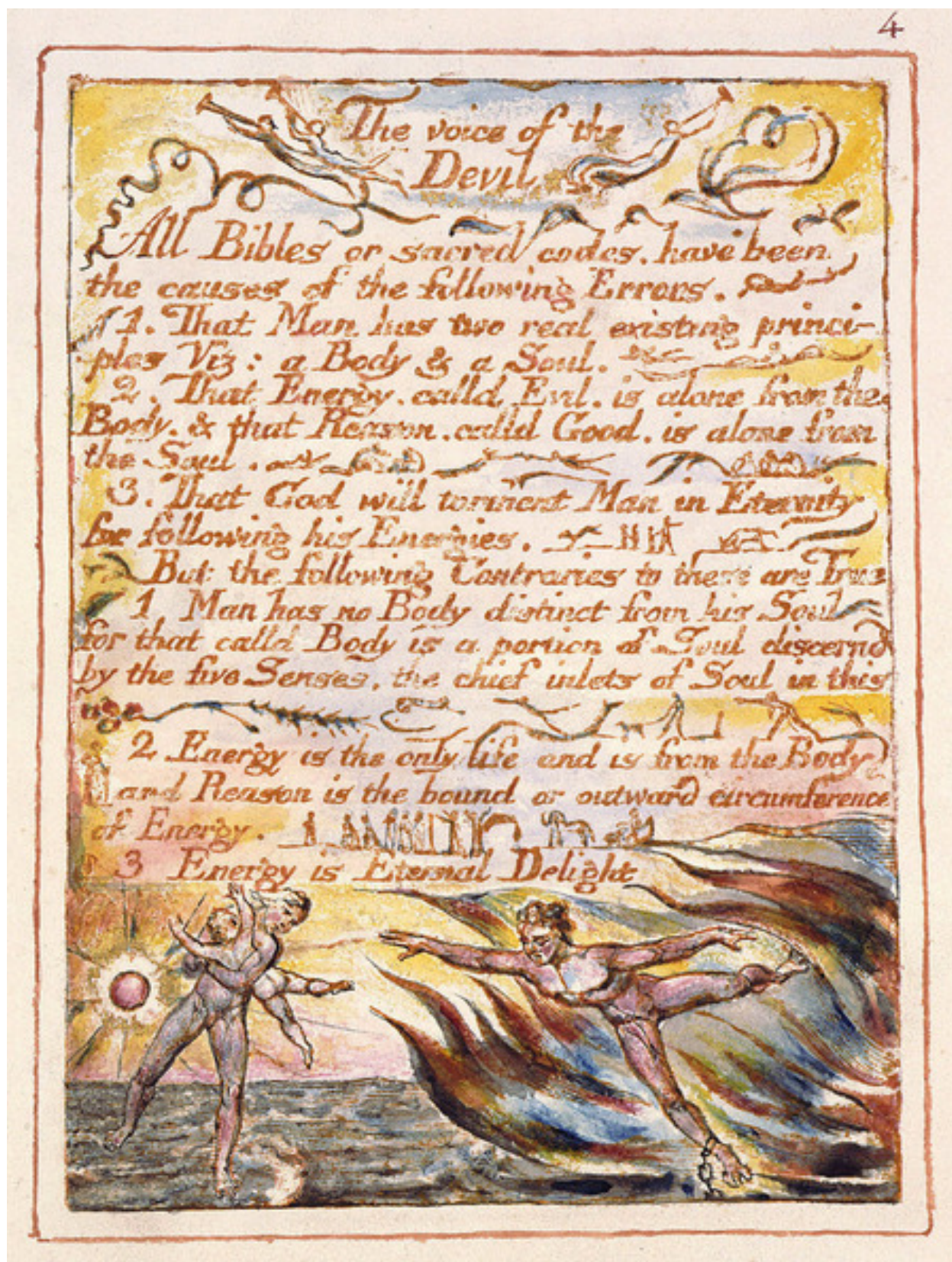


The Great Red Dragon and the Woman Clothed in the Sun, watercolor

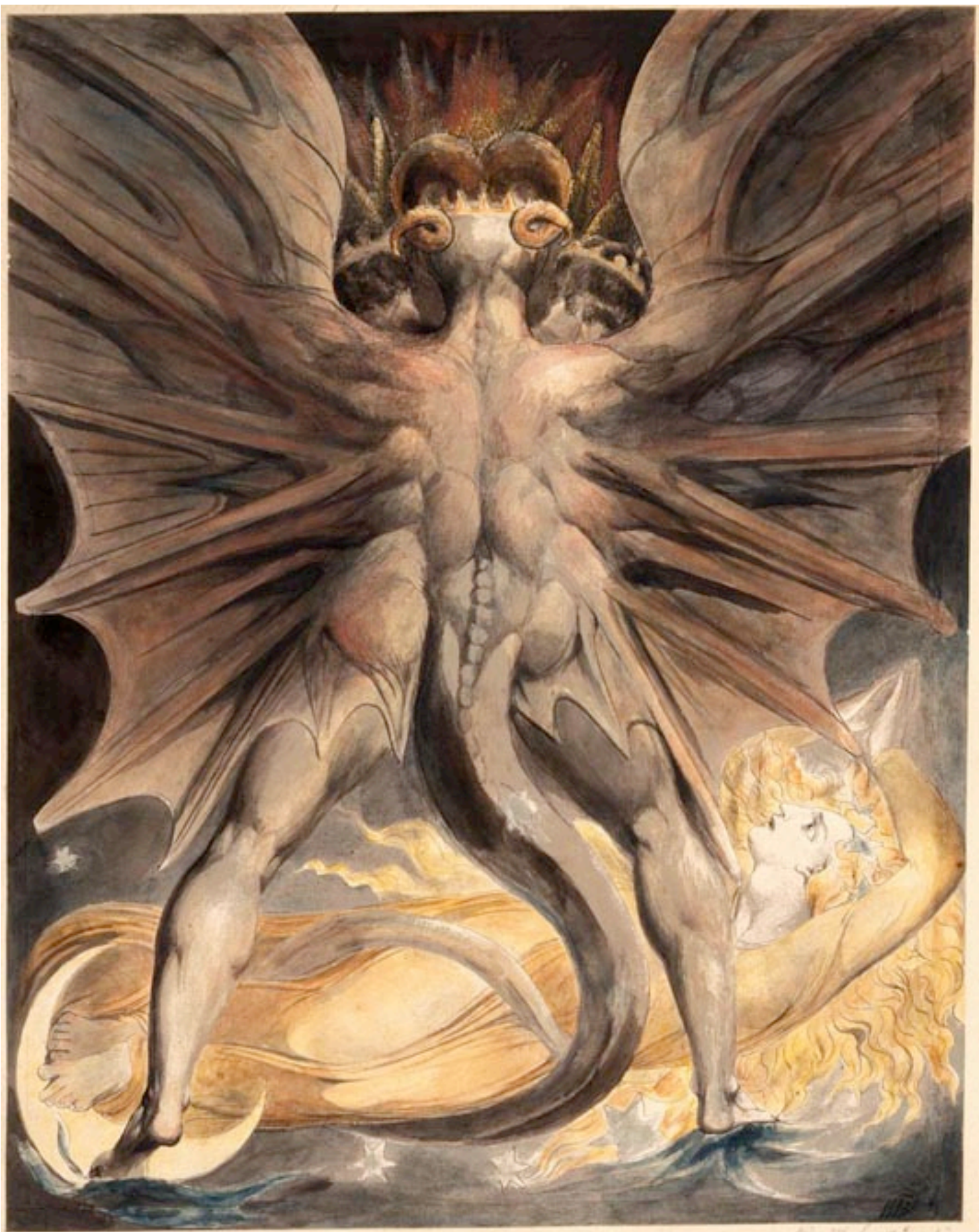




\section{Appendix C}

\section{Blake's Engraving Process}

* from Jonathan Roberts's William Blake's Poetry: A Reader's Guide, pg. 75-76.

There has been a good deal of experimentation by printmakers (including the Spanish artist Joan Miró) and scholars to work out Blake's methods, and the account which follows is entirely based on the very detailed work of Robert N. Essick in William Blake: Printmaker, and particularly on Joseph Viscomi's account in Blake and the Idea of the Book.

Blake bought copper in large sheets which were cut to size either by being scored and snapped, or 'by being cut with a hammer and chisel on an anvil' (Viscomi, 48). The plates were polished to a mirror surface using pumice, charcoal, and finally oil and felt, and the surface was then degreased using either stale bread, ammonia and whiting (ground chalk), or dilute nitric acid (Viscomi, 48-9). This allowed the ink to grip the sheet, and, if nitric acid was used, it would have created a matt key to the surface, making it easier to work on. In normal etching practice the whole plate would be coated with an even acid-resistant ground which, once dry, would take a design scratched into it using an engraving needle. In creating the illuminated books, however, Blake worked in a different manner. No ground was used, but instead the design and reverse-writing were applied with brush and pen, using stop-out varnish - probably either a natural bitumen such as asphalt, or ground resin dissolved in turpentine or alcohol. This may have been mixed with an oil to slow down the drying process so that the fluid would not harden on the brush (Viscomi, 53).

The writing was probably executed using a normal quill, and the illustrations drawn on with the same, then washed or detailed with brushes (Viscomi, $57 \mathrm{ff}$ ). When the ink had dried it would be hard and could be scratched into with a needle, allowing fine detail to be added. The hardening quality of the stop-out varnish also meant that it could be chipped off and reapplied, giving some scope for the correction of errors. After the design had been completed, a wax wall was built around the edge of the plate, and acid (probably nitric) was poured in. The reaction of copper and acid produces gas bubbles, which were removed using a feather to ensure that there was no pitting of the plate. When the bite was sufficiently deep (only about a tenth of a millimeter) the plate was removed from the acid, rinsed thoroughly, and the stop (which would have remained on the plate) was removed with turpentine. The creation of the plate now complete, and it was ready to be inked and used for printing (Viscomi, 78ff). 


\section{Appendix D}

\section{List of Standard Variations in English Metrics}

* from Alicia Ostriker's essay, "Metrics: Pattern and Variation" in Twentieth Century Interpretations of Songs of Innocence and of Experience: A Collection of Critical Essays, edited by Morton D. Paley, pg. 17-18.

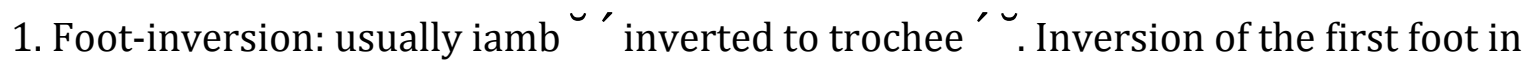
iambic meters was a variation common enough to pass uncensored by Augustan critics. Internal inversion was uncommon and final-foot inversion was ignored or condemned by almost everyone, although Milton unquestionably uses it in several lines. A notable Romantic example is Keats' "Bright star! Would I were steadfast as thou art." In trochaic and other meters, inversion rarely occurs.

2. Foot-distention: use of more than one stress in a foot, as in a spondee ' 'Eighteenthcentury writers used spondees, though they may not have called them that; e.g., Pope's "Shut, shut the door, good John!"

3. Foot-substitutions: use of trisyllabic foot for a disyllable, or vice versa. Discovery of this 'new' principle, generally ignored in the eighteenth century, was Coleridge's great announcement in the preface to Christabel. On the same principle is:

4. Incomplete or monosyllabic foot: a syllable is dropped, or pause takes the place of a syllable, as in music. The class example is Tennyson's

Break, break, break, On thy cold grey stones, 0 sea!

Not affecting the scansion as such, but also used to avoid monotonous cadence are:

1. Enjambment: run-on or absence of pause at the close of the line.

2. Use of pause or caesura within the line: variation of its position.

3. Accentual variation: (a) light or omitted accent on a syllable in stress position - usually admissible anywhere but in the last foot, and sometimes occurring there also; (b)

variations in degree of normal stress, indicated, from primary to secondary to tertiary, by ', $\hat{,}$, , in the notation currently used in American linguistics. These distinctions, although not ordinarily perceived consciously by an untrained ear, help order the meaning of sentences to us.

4. Variations in tempo, produced partly by heaviness of accent and pause, partly by presence or absence of long vowels or diphthongs, liquidity or clustering of consonants. 


\section{Appendix E}

\section{Songs of Innocence and of Experience}

Plates for Analysis

* from Songs of Innocence and of Experience, edited by Andrew Lincoln

\section{“London"}

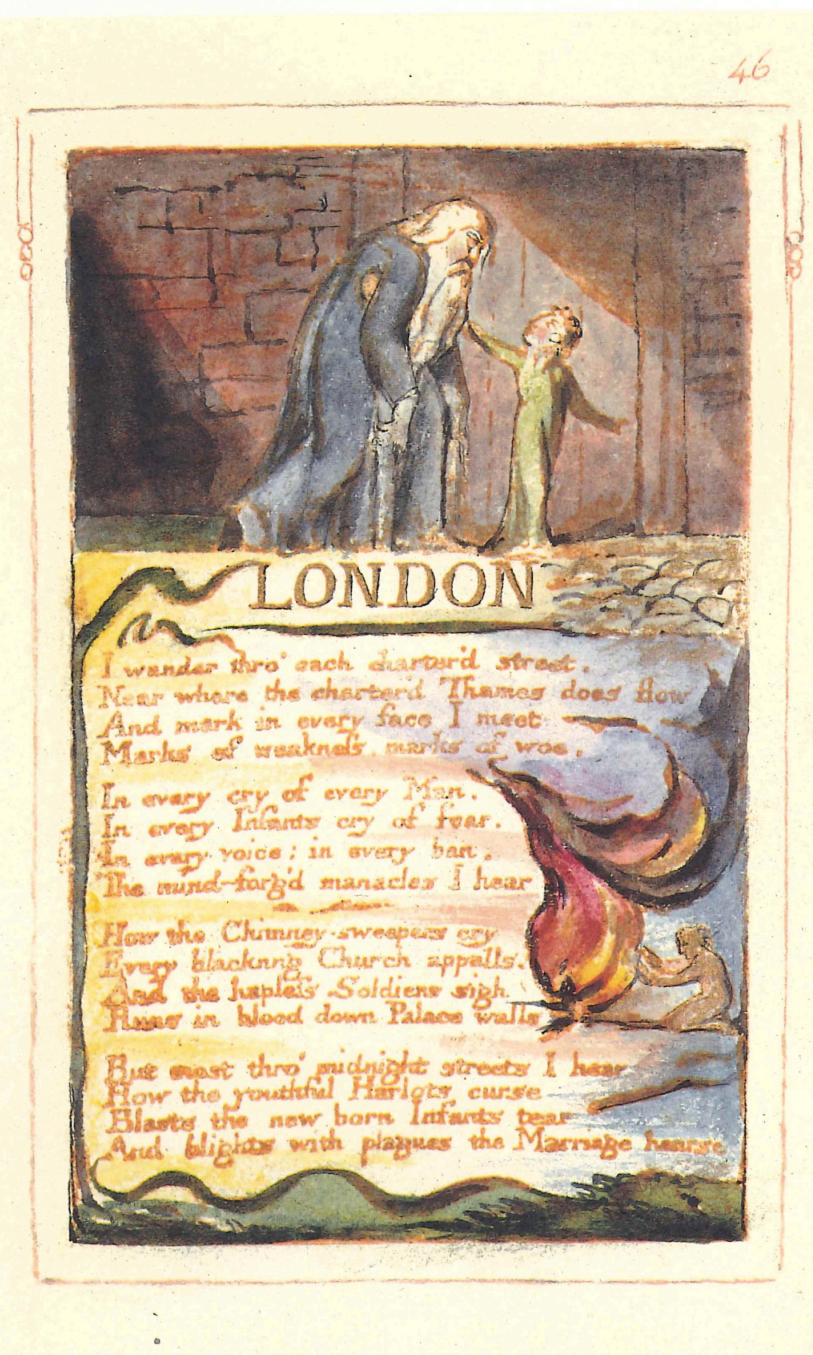


"A Poison Tree"

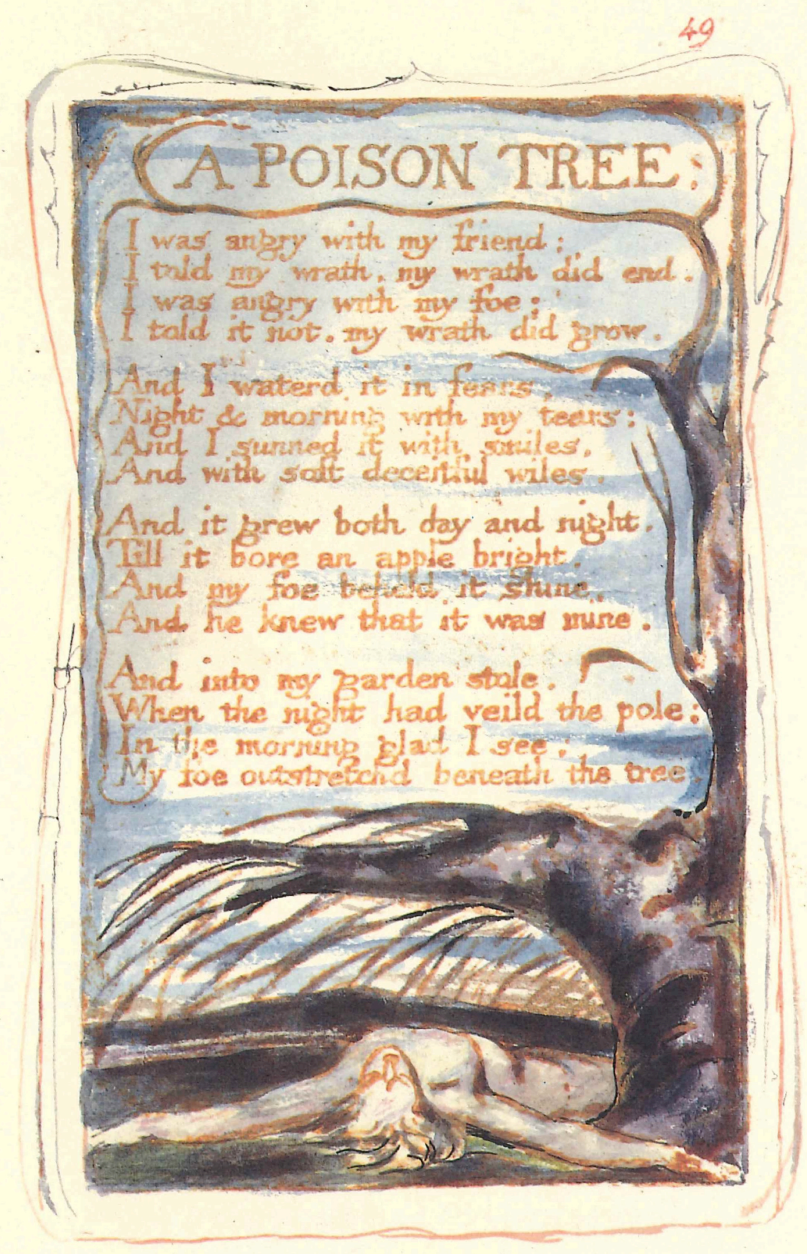


"The Fly"

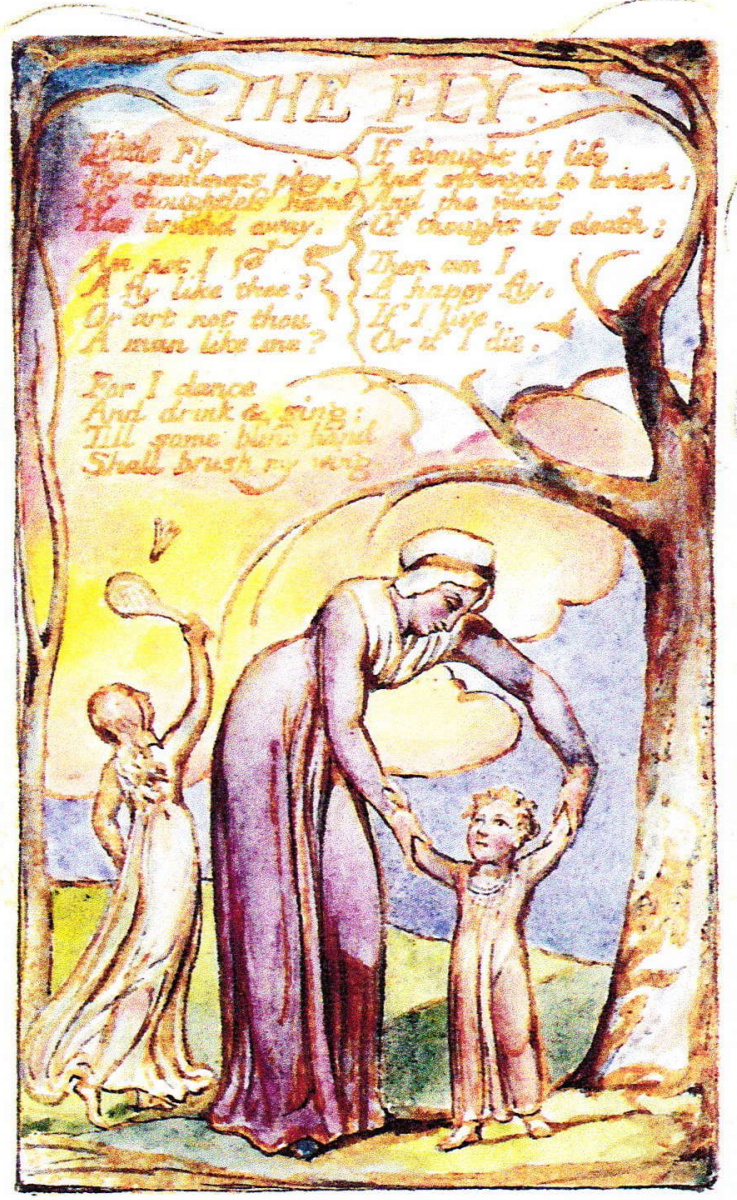




\section{"The Lamb"}

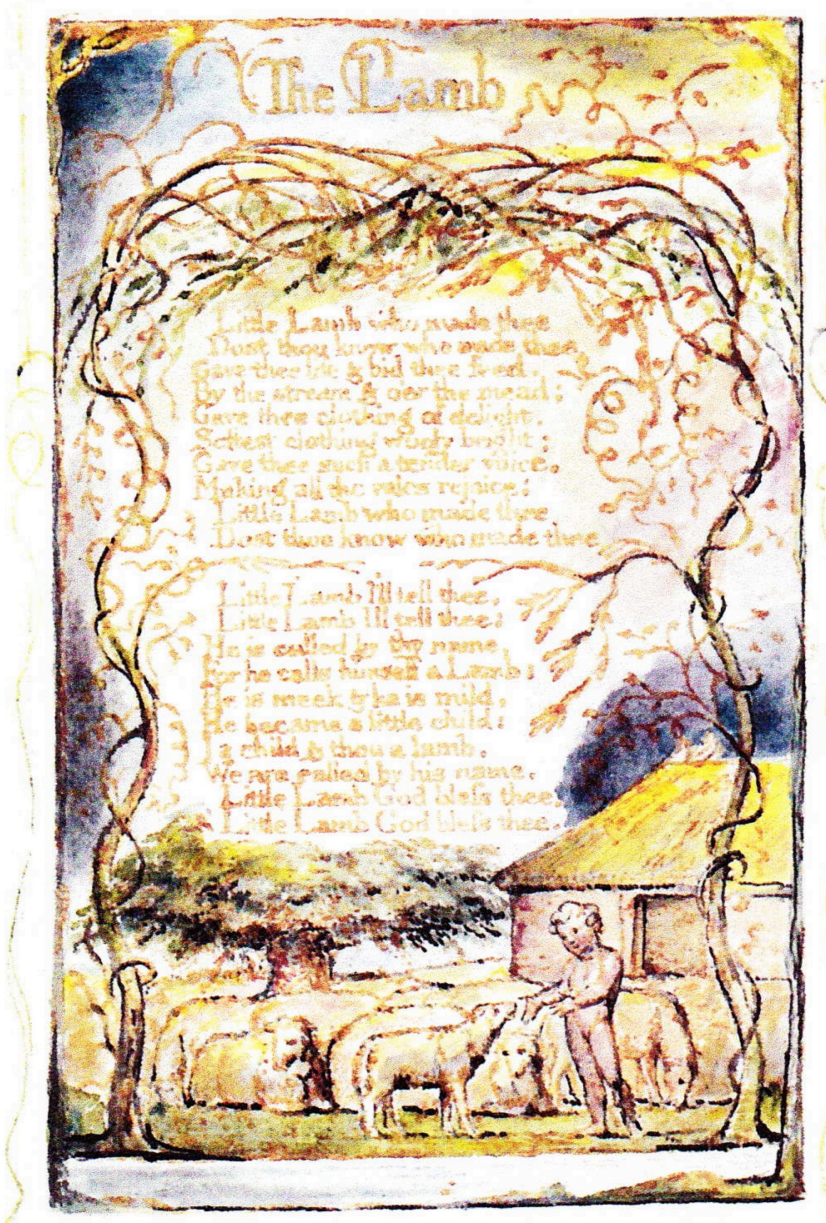




\section{"The Tyger"}

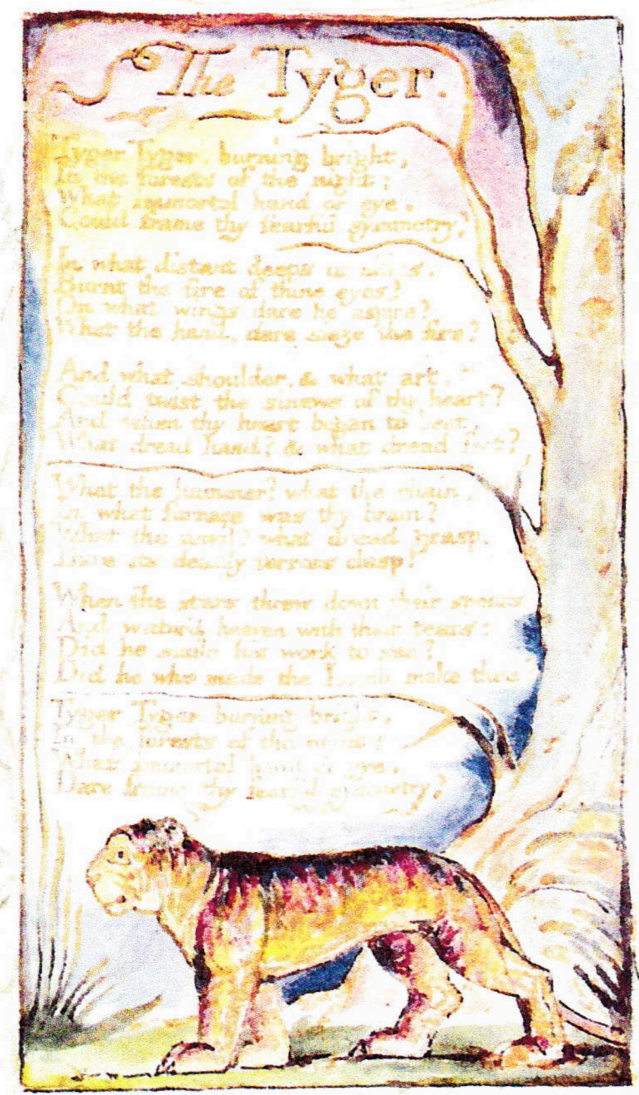


"Ah! Sun-flower"

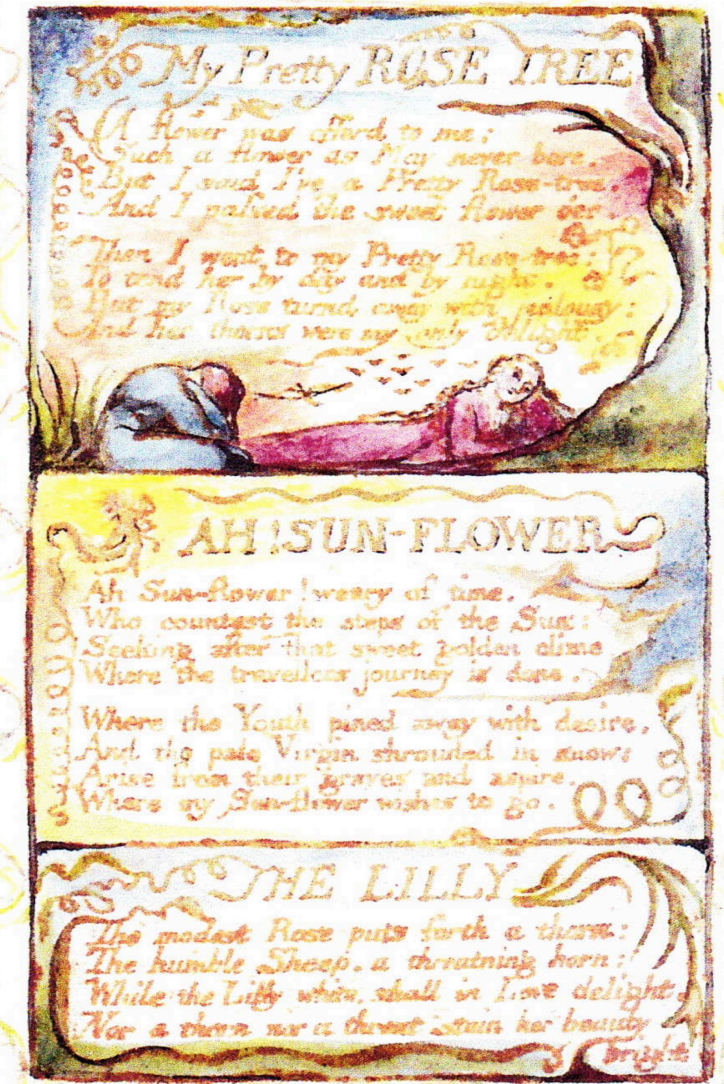




\section{Appendix F}

Tone Row Matrix

Rochberg's Blake Songs

Pitch Names

\begin{tabular}{|l|l|l|l|l|l|l|l|l|l|l|l|l|l|}
\hline & $\mathrm{I}_{9}$ & $\mathrm{I}_{10}$ & $\mathrm{I}_{3}$ & $\mathrm{I}_{4}$ & $\mathrm{I}_{0}$ & $\mathrm{I}_{1}$ & $\mathrm{I}_{2}$ & $\mathrm{I}_{5}$ & $\mathrm{I}_{6}$ & $\mathrm{I}_{7}$ & $\mathrm{I}_{8}$ & $\mathrm{I}_{11}$ & \\
\hline $\mathrm{P}_{9}$ & $\mathrm{~A}$ & $\mathrm{~B} b$ & $\mathrm{E} b$ & $\mathrm{E}$ & $\mathrm{C}$ & $\mathrm{C} \#$ & $\mathrm{D}$ & $\mathrm{F}$ & $\mathrm{F} \#$ & $\mathrm{G}$ & $\mathrm{G} \#$ & $\mathrm{~B}$ & $\mathrm{R}_{9}$ \\
\hline $\mathrm{P}_{8}$ & $\mathrm{G} \#$ & $\mathrm{~A}$ & $\mathrm{D}$ & $\mathrm{E} b$ & $\mathrm{~B}$ & $\mathrm{C}$ & $\mathrm{C} \#$ & $\mathrm{E}$ & $\mathrm{F}$ & $\mathrm{F} \#$ & $\mathrm{G}$ & $\mathrm{B} b$ & $\mathrm{R}_{8}$ \\
\hline $\mathrm{P}_{3}$ & $\mathrm{E} b$ & $\mathrm{E}$ & $\mathrm{A}$ & $\mathrm{B} b$ & $\mathrm{~F} \#$ & $\mathrm{G}$ & $\mathrm{G} \#$ & $\mathrm{~B}$ & $\mathrm{C}$ & $\mathrm{C} \#$ & $\mathrm{D}$ & $\mathrm{F}$ & $\mathrm{R}_{3}$ \\
\hline $\mathrm{P}_{2}$ & $\mathrm{D}$ & $\mathrm{E} b$ & $\mathrm{G} \#$ & $\mathrm{~A}$ & $\mathrm{~F}$ & $\mathrm{~F} \#$ & $\mathrm{G}$ & $\mathrm{B} b$ & $\mathrm{~B}$ & $\mathrm{C}$ & $\mathrm{C} \#$ & $\mathrm{E}$ & $\mathrm{R}_{2}$ \\
\hline $\mathrm{P}_{6}$ & $\mathrm{~F} \#$ & $\mathrm{G}$ & $\mathrm{C}$ & $\mathrm{C} \#$ & $\mathrm{~A}$ & $\mathrm{~B} b$ & $\mathrm{~B}$ & $\mathrm{D}$ & $\mathrm{E} b$ & $\mathrm{E}$ & $\mathrm{F}$ & $\mathrm{G} \#$ & $\mathrm{R}_{6}$ \\
\hline $\mathrm{P}_{5}$ & $\mathrm{~F}$ & $\mathrm{~F} \#$ & $\mathrm{~B}$ & $\mathrm{C}$ & $\mathrm{G} \#$ & $\mathrm{~A}$ & $\mathrm{~B} b$ & $\mathrm{C} \#$ & $\mathrm{D}$ & $\mathrm{E} b$ & $\mathrm{E}$ & $\mathrm{G}$ & $\mathrm{R}_{5}$ \\
\hline $\mathrm{P}_{4}$ & $\mathrm{E}$ & $\mathrm{F}$ & $\mathrm{B} b$ & $\mathrm{~B}$ & $\mathrm{G}$ & $\mathrm{G} \#$ & $\mathrm{~A}$ & $\mathrm{C}$ & $\mathrm{C} \#$ & $\mathrm{D}$ & $\mathrm{E} b$ & $\mathrm{~F} \#$ & $\mathrm{R}_{4}$ \\
\hline $\mathrm{P}_{1}$ & $\mathrm{C} \#$ & $\mathrm{D}$ & $\mathrm{G}$ & $\mathrm{G} \#$ & $\mathrm{E}$ & $\mathrm{F}$ & $\mathrm{F} \#$ & $\mathrm{~A}$ & $\mathrm{~B} b$ & $\mathrm{~B}$ & $\mathrm{C}$ & $\mathrm{E} b$ & $\mathrm{R}_{1}$ \\
\hline $\mathrm{P}_{0}$ & $\mathrm{C}$ & $\mathrm{C} \#$ & $\mathrm{~F} \#$ & $\mathrm{G}$ & $\mathrm{E} b$ & $\mathrm{E}$ & $\mathrm{F}$ & $\mathrm{G} \#$ & $\mathrm{~A}$ & $\mathrm{~B} b$ & $\mathrm{~B}$ & $\mathrm{D}$ & $\mathrm{R}_{0}$ \\
\hline $\mathrm{P}_{11}$ & $\mathrm{~B}$ & $\mathrm{C}$ & $\mathrm{F}$ & $\mathrm{F} \#$ & $\mathrm{D}$ & $\mathrm{E} b$ & $\mathrm{E}$ & $\mathrm{G}$ & $\mathrm{G} \#$ & $\mathrm{~A}$ & $\mathrm{~B} b$ & $\mathrm{C} \#$ & $\mathrm{R}_{11}$ \\
\hline $\mathrm{P}_{10}$ & $\mathrm{~B} b$ & $\mathrm{~B}$ & $\mathrm{E}$ & $\mathrm{F}$ & $\mathrm{C} \#$ & $\mathrm{D}$ & $\mathrm{E} b$ & $\mathrm{~F} \#$ & $\mathrm{G}$ & $\mathrm{G} \#$ & $\mathrm{~A}$ & $\mathrm{C}$ & $\mathrm{R}_{10}$ \\
\hline $\mathrm{P}_{7}$ & $\mathrm{G}$ & $\mathrm{G} \#$ & $\mathrm{C} \#$ & $\mathrm{D}$ & $\mathrm{B} b$ & $\mathrm{~B}$ & $\mathrm{C}$ & $\mathrm{E} b$ & $\mathrm{E}$ & $\mathrm{F}$ & $\mathrm{F}$ & $\mathrm{A}$ & $\mathrm{R}_{7}$ \\
\hline & $\mathrm{RI}$ & $\mathrm{RI}_{10}$ & $\mathrm{RI}_{3}$ & $\mathrm{RI}_{4}$ & $\mathrm{RI}_{0}$ & $\mathrm{RI}_{1}$ & $\mathrm{RI}_{2}$ & $\mathrm{RI}_{5}$ & $\mathrm{RI}_{6}$ & $\mathrm{RI}_{7}$ & $\mathrm{RI}_{8}$ & $\mathrm{RI}_{11}$ & \\
\hline
\end{tabular}

Numbers

\begin{tabular}{|l|l|l|l|l|l|l|l|l|l|l|l|l|l|}
\hline & $\mathrm{I}_{9}$ & $\mathrm{I}_{10}$ & $\mathrm{I}_{3}$ & $\mathrm{I}_{4}$ & $\mathrm{I}_{0}$ & $\mathrm{I}_{1}$ & $\mathrm{I}_{2}$ & $\mathrm{I}_{5}$ & $\mathrm{I}_{6}$ & $\mathrm{I}_{7}$ & $\mathrm{I}_{8}$ & $\mathrm{I}_{11}$ & \\
\hline $\mathrm{P}_{9}$ & 9 & 10 & 3 & 4 & 0 & 1 & 2 & 5 & 6 & 7 & 8 & 11 & $\mathrm{R}_{9}$ \\
\hline $\mathrm{P}_{8}$ & 8 & 9 & 2 & 3 & 11 & 0 & 1 & 4 & 5 & 6 & 7 & 10 & $\mathrm{R}_{8}$ \\
\hline $\mathrm{P}_{3}$ & 3 & 4 & 9 & 10 & 6 & 7 & 8 & 11 & 0 & 1 & 2 & 5 & $\mathrm{R}_{3}$ \\
\hline $\mathrm{P}_{2}$ & 2 & 3 & 8 & 9 & 5 & 6 & 7 & 10 & 11 & 0 & 1 & 4 & $\mathrm{R}_{2}$ \\
\hline $\mathrm{P}_{6}$ & 6 & 7 & 0 & 1 & 9 & 10 & 11 & 2 & 3 & 4 & 5 & 8 & $\mathrm{R}_{6}$ \\
\hline $\mathrm{P}_{5}$ & 5 & 6 & 11 & 0 & 8 & 9 & 10 & 1 & 2 & 3 & 4 & 7 & $\mathrm{R}_{5}$ \\
\hline $\mathrm{P}_{4}$ & 4 & 5 & 10 & 11 & 7 & 8 & 9 & 0 & 1 & 2 & 3 & 6 & $\mathrm{R}_{4}$ \\
\hline $\mathrm{P}_{1}$ & 1 & 2 & 7 & 8 & 4 & 5 & 6 & 9 & 10 & 11 & 0 & 3 & $\mathrm{R}_{1}$ \\
\hline $\mathrm{P}_{0}$ & 0 & 1 & 6 & 7 & 3 & 4 & 5 & 8 & 9 & 10 & 11 & 2 & $\mathrm{R}_{0}$ \\
\hline $\mathrm{P}_{11}$ & 11 & 0 & 5 & 6 & 2 & 3 & 4 & 7 & 8 & 9 & 10 & 1 & $\mathrm{R}_{11}$ \\
\hline $\mathrm{P}_{10}$ & 10 & 11 & 4 & 5 & 1 & 2 & 3 & 6 & 7 & 8 & 9 & 0 & $\mathrm{R}_{10}$ \\
\hline $\mathrm{P}_{7}$ & 7 & 8 & 1 & 2 & 10 & 11 & 0 & 3 & 4 & 5 & 6 & 9 & $\mathrm{R}_{7}$ \\
\hline & $\mathrm{RI}_{9}$ & $\mathrm{RI}_{10}$ & $\mathrm{RI}_{3}$ & $\mathrm{RI}_{4}$ & $\mathrm{RI}_{0}$ & $\mathrm{RI}_{1}$ & $\mathrm{RI}_{2}$ & $\mathrm{RI}_{5}$ & $\mathrm{RI}_{6}$ & $\mathrm{RI}_{7}$ & $\mathrm{RI}_{8}$ & $\mathrm{RI}_{11}$ & \\
\hline
\end{tabular}

